\title{
Salinization of the Upper Colorado River- Fingerprinting Geologic Salt Sources
}

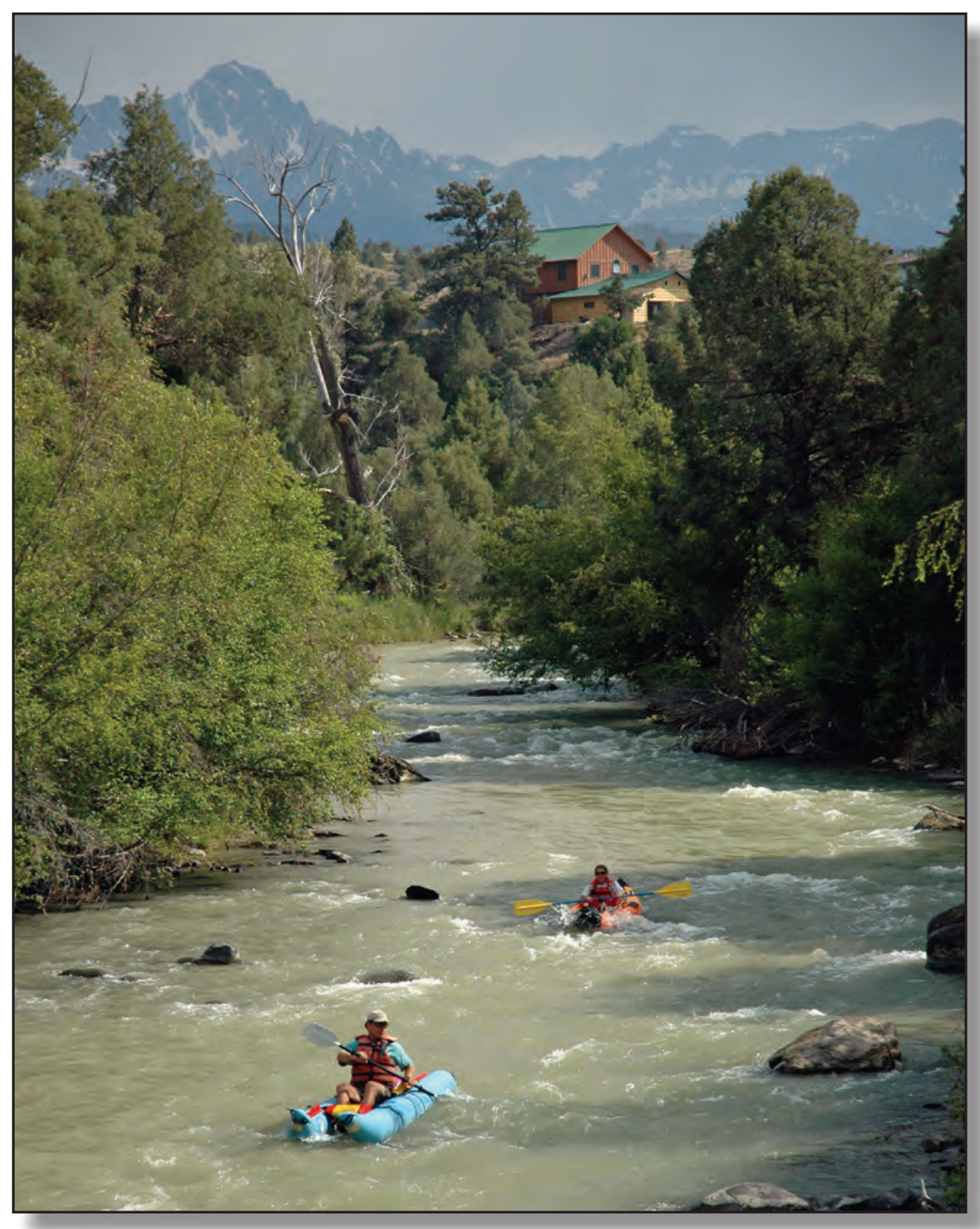

Scientific Investigations Report 2009-5072 
COVER: Uncompahgre River near Ridgway, Colorado.

Photograph by John G. Elliott, U.S. Geological Survey, July 20, 2005. 


\section{Salinization of the Upper Colorado River- Fingerprinting Geologic Salt Sources}

By Michele L. Tuttle and Richard I. Grauch

Scientific Investigations Report 2009-5072 


\title{
U.S. Department of the Interior \\ KEN SALAZAR, Secretary
}

\author{
U.S. Geological Survey \\ Suzette M. Kimball, Acting Director
}

\section{U.S. Geological Survey, Reston, Virginia: 2009}

\begin{abstract}
For more information on the USGS - the Federal source for science about the Earth, its natural and living resources, natural hazards, and the environment, visit http://www.usgs.gov or call 1-888-ASK-USGS

For an overview of USGS information products, including maps, imagery, and publications, visit http://www.usgs.gov/pubprod

To order this and other USGS information products, visit http://store.usgs.gov
\end{abstract}

Any use of trade, product, or firm names is for descriptive purposes only and does not imply endorsement by the U.S. Government.

Although this report is in the public domain, permission must be secured from the individual copyright owners to reproduce any copyrighted materials contained within this report.

Suggested citation:

Tuttle, M.L., and Grauch, R.I., 2009, Salinization of the upper Colorado River-Fingerprinting geologic salt sources: U.S. Geological Survey Scientific Investigations Report 2009-5072, 62 p. 


\section{Contents}

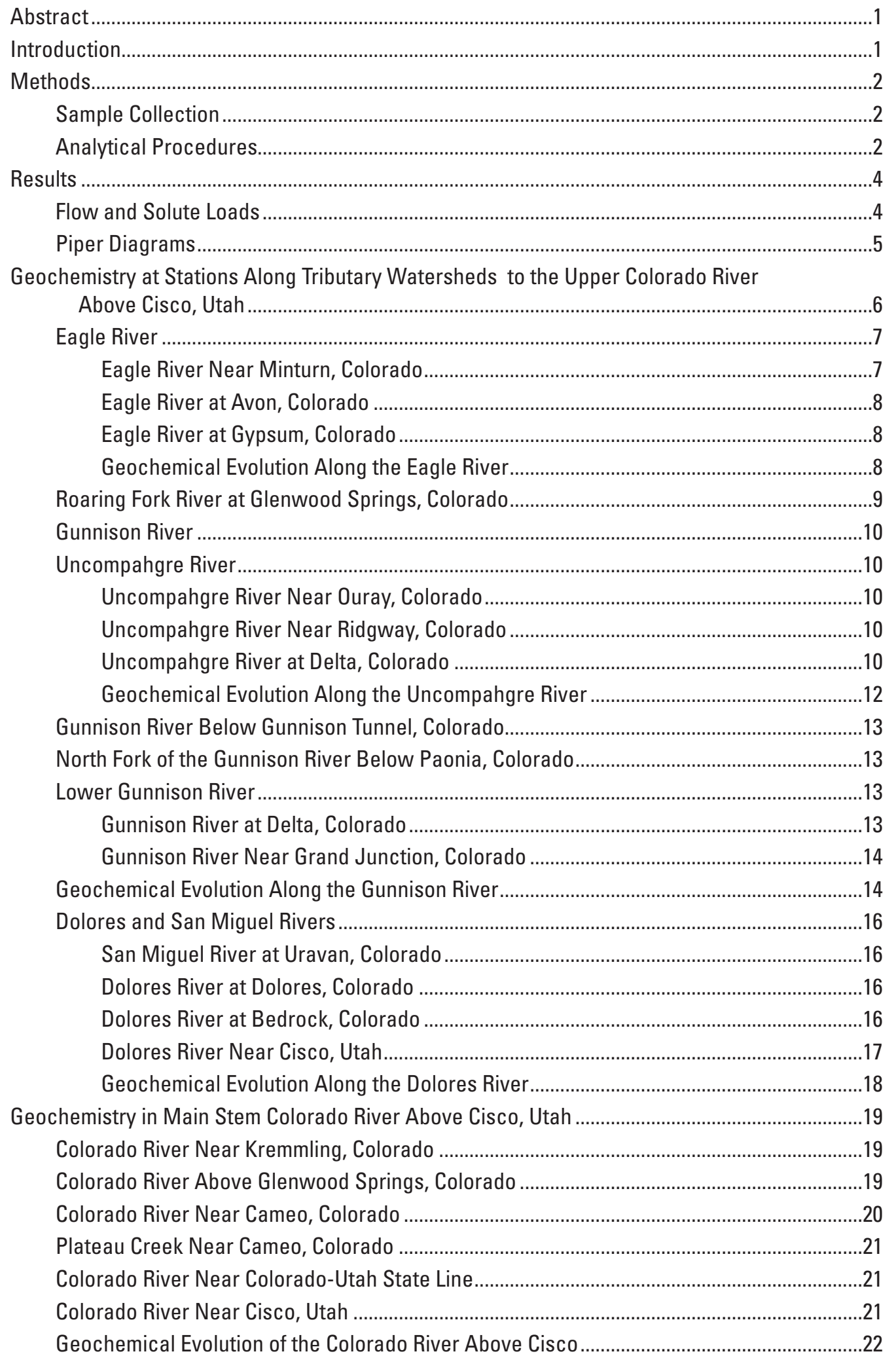




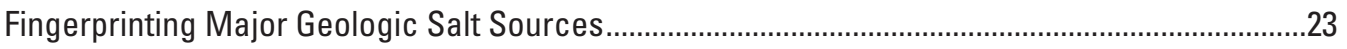

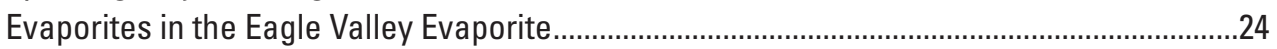

Evaporites in the Paradox Formation ................................................................................24

Salts Derived From Weathering of the Mancos Shale ……..................................................25

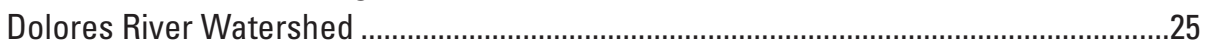

Gunnison River Watershed .......................................................................................25

Colorado River Headwater-Plateau Watershed ................................................................26

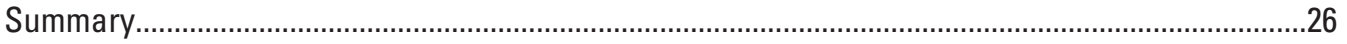

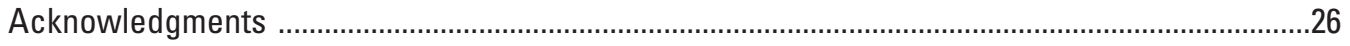

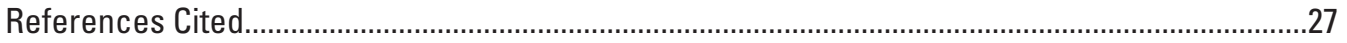

Appendix I. Chemical and Isotopic Data for All Water Samples Collected in This Study............30

Appendix II. Chemical Loads for Major Chemical Elements and Total Solutes .............................50

Appendix III. Chemical, Isotopic, and Mineralogical Data for All Geologic Samples

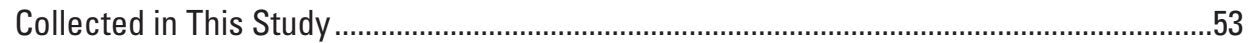

\section{Figures}

1. Map showing study area and sampling locations .............................................................

2. Schematic of flow during high-water, irrigation, and base flows .................................... 4

3. Schematic of total solute loads during high-water, irrigation, and base flows .................5

4. Piper plots for water during high-water flow, irrigation flow, and base flow....................6

5. Index map for watersheds considered in this study......................................................

6. Map of the Eagle River watershed ……………..................................................

7. Cross plots showing relations between isotopic composition of $\delta^{2} \mathrm{H}$ and

$\delta^{18} 0$ of water and $\delta^{18} 0$ and $\delta^{34} S$ of dissolved sulfate in the Eagle River ...........................

8. Map of Roaring Fork River watershed .....................................................................

9. Maps of the upper Gunnison River, North Fork of the Gunnison River, Uncompahgre River, and lower Gunnison River watersheds .........................................11

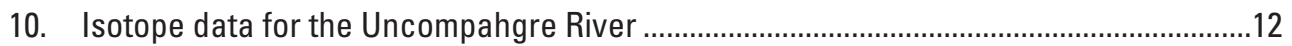

11. Isotope data for the Gunnison River, North Fork of the Gunnison River,

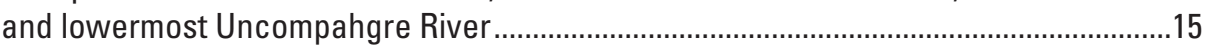

12. Map of the upper and lower Dolores River watersheds and the San Miguel River watershed ...........................................................................................................

13. Isotope data for the Dolores and San Miguel Rivers.....................................................18

14. Maps of Colorado River headwater, Colorado River headwater-plateau, and the Westwater Canyon watersheds.

15. Total load at stations along the Colorado River and at confluences with tributaries

16. Isotopic composition of water and sulfate along the main stem of the upper Colorado River at and above Cisco.

\section{Tables}

1. Methods of chemical analyses

2. Approximate distances of major tributary confluences on the Colorado River downstream from the Kremmling station 
3-9. Summary of geochemical parameters for:

3. Eagle River at Minturn ..........................................................................................

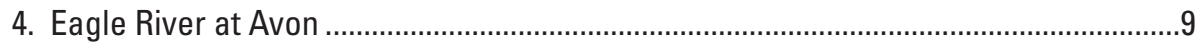

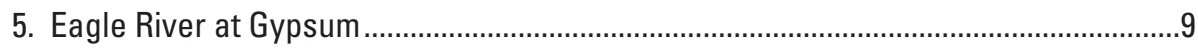

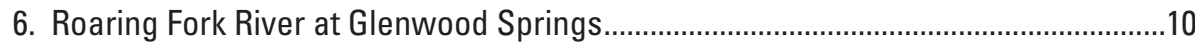

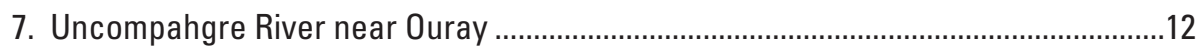

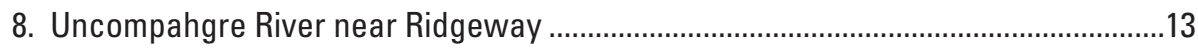

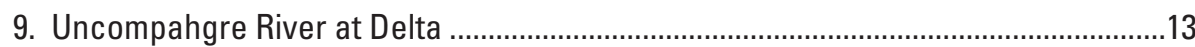

10. Stream flow, total salt load, and $\mathrm{SO}_{4}$ load for irrigation water in the Uncompahgre watershed

11-21. Summary of geochemical parameters for:

11. Gunnison River below Gunnison Tunnel..................................................................14

12. North Fork of the Gunnison River below Paonia .....................................................15

13. Gunnison River at Delta ....................................................................................16

14. Gunnison River near Grand Junction .....................................................................16

15. San Miguel River at Uravan .............................................................................

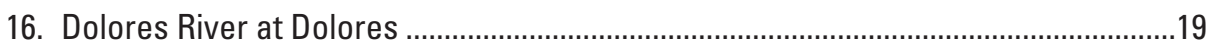

17. Dolores River at Bedrock …………………………………………………….......19

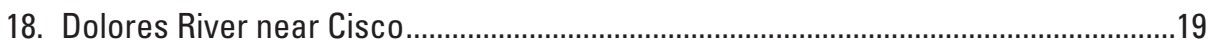

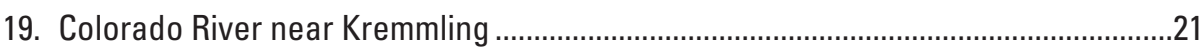

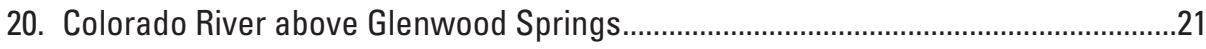

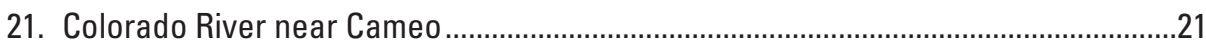

22. Sulfate loads and isotopic composition of contributions between the stations above Glenwood Springs and near Cameo on the upper Colorado River

23-25. Summary of geochemical parameters for:

23. Plateau Creek near Cameo .....................................................................................22

24. Colorado River near the Colorado-Utah State line ....................................................22

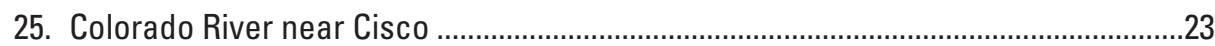

26. The 2005 estimated dissolution rates for halite and gypsum in major geologic units and a comparison of the derived solutes to the estimated annual Colorado River load at Cisco

\section{Appendix Tables}

Al-1. Metadata for reported concentrations …………..........................................................30

Al-2. Elements not reported in Appendix 1 ............................................................................31

Al-3. Chemical and isotopic data for all water samples collected in this study........................32

All-1. Conductivity and chemical load (tonnes/day) for major chemical elements ...................50

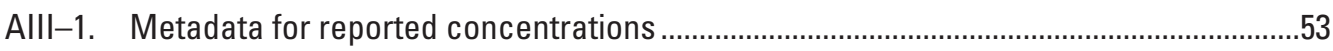

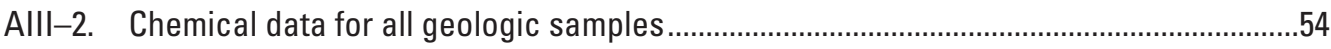

Alll-3. Sulfur isotope data for selected geologic samples .......................................................59

Alll-4. Mineralogical data for selected geologic samples ..........................................................61 



\title{
Salinization of the Upper Colorado River-Fingerprinting Geologic Salt Sources
}

\author{
By Michele L. Tuttle and Richard I. Grauch
}

\begin{abstract}
Salt in the upper Colorado River is of concern for a number of political and socioeconomic reasons. Salinity limits in the 1974 U.S. agreement with Mexico require the United States to deliver Colorado River water of a particular quality to the border. Irrigation of crops, protection of wildlife habitat, and treatment for municipal water along the course of the river also place restrictions on the river's salt content.

Most of the salt in the upper Colorado River at Cisco, Utah, comes from interactions of water with rock formations, their derived soil, and alluvium. Half of the salt comes from the Mancos Shale and the Eagle Valley Evaporite. Anthropogenic activities in the river basin (for example, mining, farming, petroleum exploration, and urban development) can greatly accelerate the release of constituents from these geologic materials, thus increasing the salt load of nearby streams and rivers. Evaporative concentration further concentrates these salts in several watersheds where agricultural land is extensively irrigated.

Sulfur and oxygen isotopes of sulfate show the greatest promise for fingerprinting the geologic sources of salts to the upper Colorado River and its major tributaries and estimating the relative contribution from each geologic formation. Knowing the salt source, its contribution, and whether the salt is released during natural weathering or during anthropogenic activities, such as irrigation and urban development, will facilitate efforts to lower the salt content of the upper Colorado River.
\end{abstract}

\section{Introduction}

Nearly 33 million people and 4 million acres of farmland in the United States and 3 million people and 500,000 farmland acres in Mexico depend on the Colorado River (U.S. Department of Interior, 2005). The Colorado River is considered one of the most stressed rivers in the world because of increasing salinization (Serageldin, 2000), transporting 9 million tons of dissolved salt each year. Roughly half of this salinity is from irrigation of agricultural fields, reservoirs, industry, and urbanization, and half from natural weathering. Salinity damages are estimated at \$306 million in the United States alone (U.S. Department of Interior, 2005) and \$1 billion per year overall (U.S. Water News Online, 1995). In accordance with requirements of the Clean Water Act, one million tons of salt per year have been controlled as of 2004, with a target control of 1.8 million tons per year by 2025 , set by the Salinity Control Forum in 2002 (cited in U.S. Department of Interior, 2005). Achieving this target control standard requires identification of natural nonpoint sources (soils, geologic formations, and stream channels and banks) and an understanding of processes by which salinization occurs during irrigation and natural weathering. Evaluating the impact of these nonpoint sources is difficult; however, recent application of diagnostic geochemical tracers yielded successful results in other river systems (Vengosh, 2004).

In 2005, an estimated 5.8 million tons of salt was acquired by the Colorado River in the upper Colorado River basin (http://www.usbr.gov/uc/progact/salinity/index.html), a large portion of which is the focus of this study. The upper Colorado River and its tributary watersheds are located in mostly sparsely populated areas in mountainous terrain or in valleys that support agriculture; therefore, most solutes come primarily from geologic sources (such as rocks, soils, alluvium, and pediments). River reaches that travel through larger communities (Grand Junction being the largest with a population of around 126,000 at the time of this report) undoubtedly acquire some solutes from point sources such as municipal waste or industrial effluent; however, these contributions are small relative to those from geologic sources (Spahr and others, 2000).

Solutes in ground and surface water are released from geologic sources through natural weathering, or anthropogenic activities such as land development, mining, and irrigation. The major elements that make up the largest proportion of solutes in ground and surface water are calcium $(\mathrm{Ca})$, magnesium $(\mathrm{Mg})$, sodium $(\mathrm{Na})$, potassium $(\mathrm{K})$, chloride $(\mathrm{Cl})$, sulfate $\left(\mathrm{SO}_{4}\right)$, and bicarbonate $\left(\mathrm{HCO}_{3}\right)$. These solutes are generally conservative in water, although precipitation of calcite can 
occur and $\mathrm{Ca}$ and $\mathrm{Mg}$ can be adsorbed during cation exchange reactions (Plummer and others, 2003). Dissolution of carbonate rocks (calcite- $\mathrm{CaCO}_{3}$ and dolomite $-\mathrm{CaMg}\left(\mathrm{CO}_{3}\right)_{2}$ ) release $\mathrm{Ca}, \mathrm{Mg}$, and $\mathrm{HCO}_{3}$; gypsum $\left(\mathrm{CaSO}_{4} \cdot 2 \mathrm{H}_{2} \mathrm{O}\right)$ and anhydrite $\left(\mathrm{CaSO}_{4}\right)$ release $\mathrm{Ca}$ and $\mathrm{SO}_{4}$; halite $(\mathrm{NaCl})$ releases $\mathrm{Na}$ and $\mathrm{Cl}$; and silicate minerals release $\mathrm{Na}, \mathrm{Ca}, \mathrm{Mg}, \mathrm{K}$, and $\mathrm{HCO}_{3}$. During oxidation, sulfide minerals release $\mathrm{SO}_{4}$ and various metals. Reactions on the surfaces or in the interlayers of clay minerals preferentially release sodium and potassium relative to other cations.

The scientific objective of this study was two-fold: (1) develop diagnostic geochemical tracers for the major geologic sources of salt to the upper Colorado River and (2) demonstrate the use of these tracers to understanding contributions of nonpoint geologic sources of salt to the upper Colorado River. Our strategy was to collect water samples from major Colorado River tributaries and along reaches of the upper Colorado River during snowmelt runoff (high-water flow), maximum diversion and irrigation-return (irrigation flow), and base stream flow (base flow). Calculated loading of chemical constituents along with geochemical tracers (element suites, element ratios, and stable isotopes) are applied to distinguish salinity sources, the quantity of salt generated from the source, and its composition. The data represent three snapshots in time and are not meant to represent an overall average of water quality. Our results show that, although element ratios help support the identification of various geologic contributions to the upper Colorado River salt load, the isotopes of sulfate are the most useful for identifying and quantifying specific sources. Trace elements help identify contributions from weathering of mineral deposits or mining waste, water isotopes are used to evaluate the effect of evaporation on increasing loads, and "available" concentrations assess elements dissolved plus those associated with geologic materials in suspension that dissolve when acidified. The latter results have important implications for health of organisms as several environments where acidification can occur are in animal lungs and stomach, plant root zones, and amended soil.

\section{Methods}

\section{Sample Collection}

Stations (fig. 1) were chosen to balance coverage of the upper Colorado River system above Cisco, Utah, with available analytical funds and maximum watershed information. Samples were collected in 2005. At each station, flow, conductivity, and $\mathrm{pH}$ were measured in the field. The last two parameters were also measured in the laboratory; laboratory results compared favorably with field values (only laboratory measurements are reported to decrease variability inherent when using different field meters). Six water samples were collected at each station - two unfiltered and unacidified for alkalinity and water isotopes, two filtered $(0.45 \mu \mathrm{m})$ and unacidified for sulfur isotopes and major anions, one unfiltered and acidified for available cations, ${ }^{1}$ and one filtered $(0.45 \mu \mathrm{m})$ and acidified for dissolved cations. "High-water" samples were collected in May during the period when snowmelt results in high stream flow. "Irrigation" samples were collected in mid-July to mid-August when some tributaries of the upper Colorado River are affected by diversion and/or return of irrigation water. "Base flow" samples were collected in mid-October to late November during the period when runoff from irrigation and storms is approaching its minimum. Samples were filtered and acidified in the field, packed in ice, and shipped to the laboratory. Upon receipt, samples were refrigerated until analyzed.

Point-source waters (Glenwood Springs hot springs and Rifle Uranium Mill monitoring wells) were collected identically to stream samples. Composites of geologic samples were collected, transported to the laboratory, and split for various analyses.

\section{Analytical Procedures}

Water samples were analyzed for alkalinity (titration), anions (ion chromatography and gravimetrically), cations (inductive coupled plasma-atomic emission spectrometry and inductive coupled plasma-mass spectrometry), and stable isotopes of water and dissolved sulfate (mass spectrometry) (table 1). Charge balances were all less than 10 percent (average 3 percent), excepting three samples that were between 17 and 25 percent (Colorado River at Kremmling high water, Eagle River at Avon base flow, and Gunnison River below tunnel base flow). These three waters are dilute, and uncertainty in the bicarbonate analysis is suspected.

Geologic samples were completely digested using a lithium metaborate fusion or four-acid digestion (hydrochloric, nitric, perchloric, and hydrofluoric acids) and analyzed for major elements by ICP-AES and for minor and trace elements by ICP-MS (Taggert, 2002). A split was also analyzed for mineral identification and morphology under the SEM-EDX. Sulfur and oxygen isotopic composition was determined on individual sulfur species (oxygen only measured on the sulfate) and reported in standard delta notation ${ }^{3}$ (Tuttle and others, 1986;

\footnotetext{
${ }^{1}$ In this study, available cations include dissolved cations plus those dissolved or desorbed upon acidification. For this analysis, water samples are collected, acidified, and then filtered $(0.45 \mu \mathrm{m})$ just prior to analysis by ICP-MS and ICP-AES.

${ }^{2}$ Sampling periods were chosen to coincide with synoptic sampling for other studies and may not always represent the ideal sampling period.

${ }^{3} \delta(\%)=\left(R_{\text {sample }}-R_{\text {standard }}\right) \times 1,000$, where $R$ is the ratio of ${ }^{34} \mathrm{~S}:{ }^{32} \mathrm{~S},{ }^{2} \mathrm{H}:{ }^{1} \mathrm{H}$, or ${ }^{18} \mathrm{O}:{ }^{16} \mathrm{O}$, and the standards are V-CDT (Vienna Cañon Diablo Troilite) and V-SMOW (Vienna Standard Mean Ocean Water).
} 


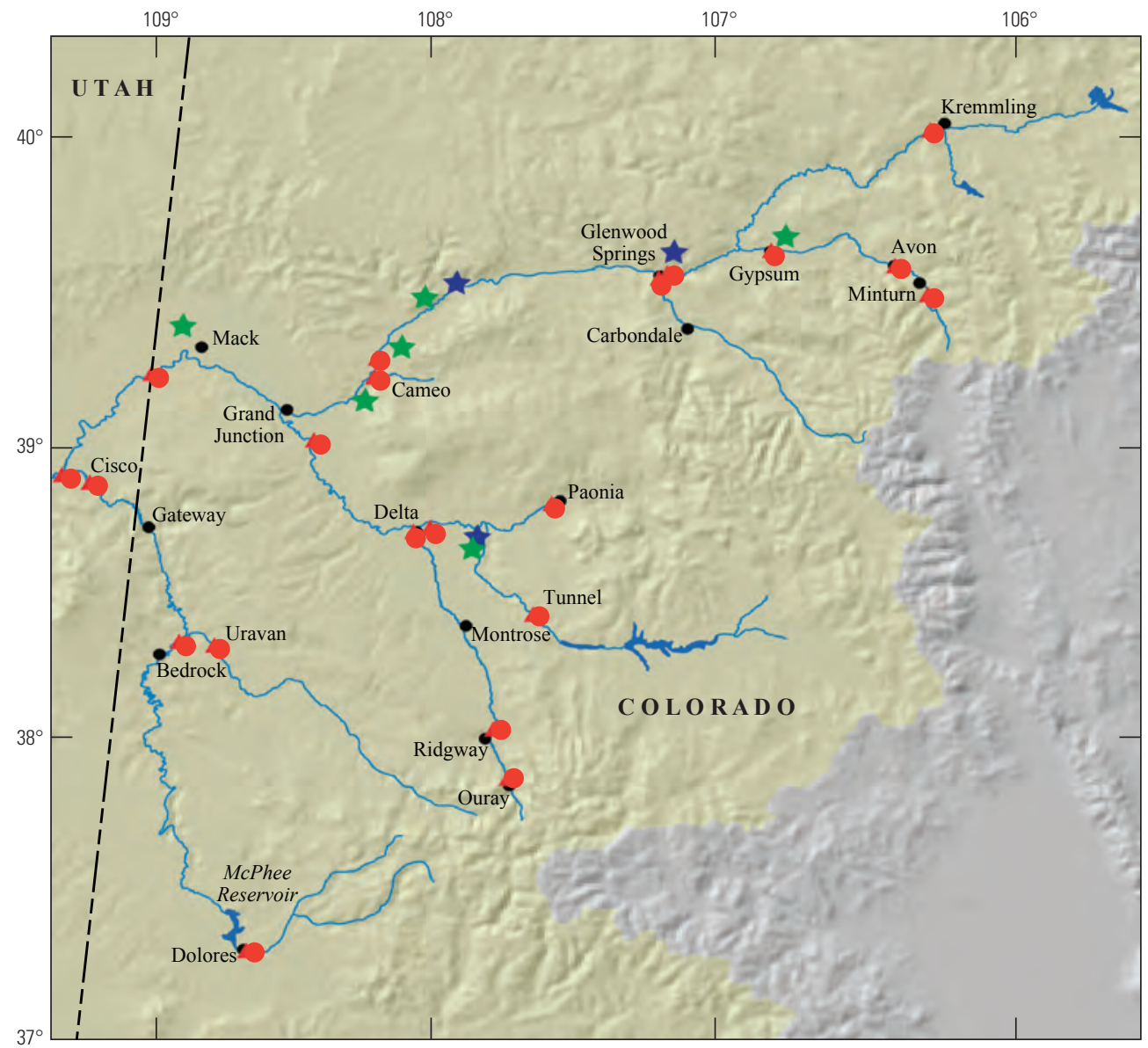

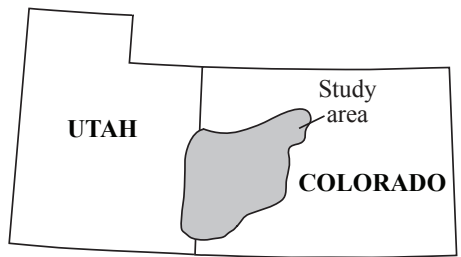

$0 \quad 50$ MILES

050 KILOMETERS
Figure 1. Map showing study area and sampling locations. Red dots, river-water samples at stream gaging stations; blue stars, pointsource water sample locations; green stars, geologic sample locations. Data for base map are from the National Elevation Dataset, available from $h t t p: / / n e d . u s g s . g o v / ;$ and the National Atlas, available from http://nationalatlas.gov/.

Table 1. Methods of chemical analyses, their abbreviation used in the appendixes, and publication references to the procedures.

[References: 1, Taggert (2002); 2, Tuttle and others (1986); 3, Giesemann and others (1995)]

\begin{tabular}{llc}
\hline \multicolumn{1}{c}{ Methods } & Abbreviation & Reference \\
\hline Carbon/hydrogen/nitrogen commercial analyzer & CHN & 1 \\
Cold vapor atomic adsorption spectrometry & CVAA & 1 \\
Combustion: SGS Laboratories (formerly XRAL), Toronto, Canada & COMB1 & 1 \\
Combustion: USGS & COMB2 & 1 \\
Coulometric titration & CT & 1 \\
Energy dispersive X-ray fluorescence & EDX & 1 \\
Graphite furnace & GF & 2 \\
Gravimetric & GRAV & 1 \\
Hydride generation atomic adsorption spectrometry & HYD & 1 \\
Ion chromatography & IC & 1 \\
Inductive coupled plasma-atomic emission spectrometry & ICP-AES & 1 \\
Inductive coupled plasma-mass spectrometry & ICP-MS & 1 \\
Ion selective electrode & ISE & 3 \\
Mass spectrometry & MS & 2 \\
Scanning electron microscopy-energy dispersive X-ray fluorescence & SEM-EDX \\
Sulfur speciation & S Spec & \\
\hline
\end{tabular}


Giesemann and others, 1995). Hydrogen and oxygen isotopes of water were commercially analyzed and reported in standard delta notation $^{3}$ relative to $\mathrm{V}-\mathrm{SMOW}$.

\section{Results}

Individual chemical and isotopic results are presented in Appendixes I and III. In this study, we report two concentrations for each cation-aqueous (aq), which is operationally defined as dissolved (the filtered sample), and available (avail), which is defined as the dissolved concentration at the time of sampling plus those elements that dissolve or exchange upon acidification of the sample (the unfiltered sample). In this report, "available" data are only discussed with respect to transport of metals adsorbed to oxides and clays.

\section{Flow and Solute Loads}

Solute (chemical) loads in $10^{3} \mathrm{~kg} / \mathrm{d}$ (tonnes solute/day) (Appendix II) have been calculated for all major chemical constituents (aqueous and available) as the product between chemical concentration and flow at the time of sampling. Segment schematics for flow and total loads are shown in figures 2 and 3 . When a constituent concentration remains constant, loads increase or decrease with flow rates. In

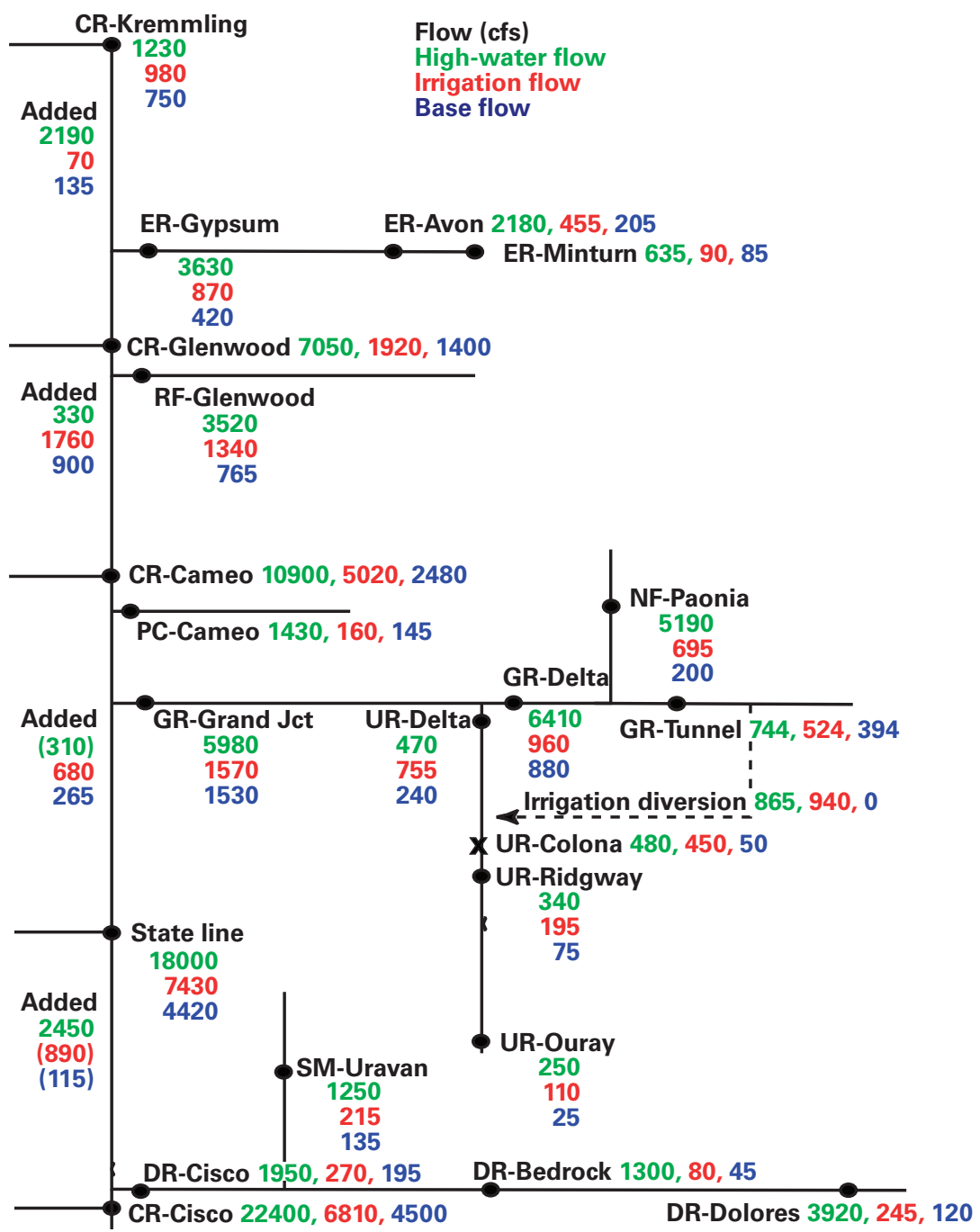

Figure 2. Schematic of flow in cubic feet per second (cfs) during high-water, irrigation, and base flows (not to scale). Also included are flows from irrigation diversion through the Gunnison Tunnel into the Uncompahgre watershed (dashed line; Paul Davidson, Bureau of Reclamation, written commun., 2007) and flows from the Ridgway State Dam at Colona (X symbol; USGS stream gaging data at http://waterdata.usgs.gov/nwis/uv?09147500). "Added" values are the increase in flow (calculated as the difference between stations along the Colorado River and represents added flow not directly measured in this study). CR, Colorado River; ER, Eagle River; RF, Roaring Fork River; PC, Plateau Creek; GR, Gunnison River; NF, North Fork of the Gunnison River; UR, Uncompahgre River; SM, San Miguel River; DR, Dolores River. 


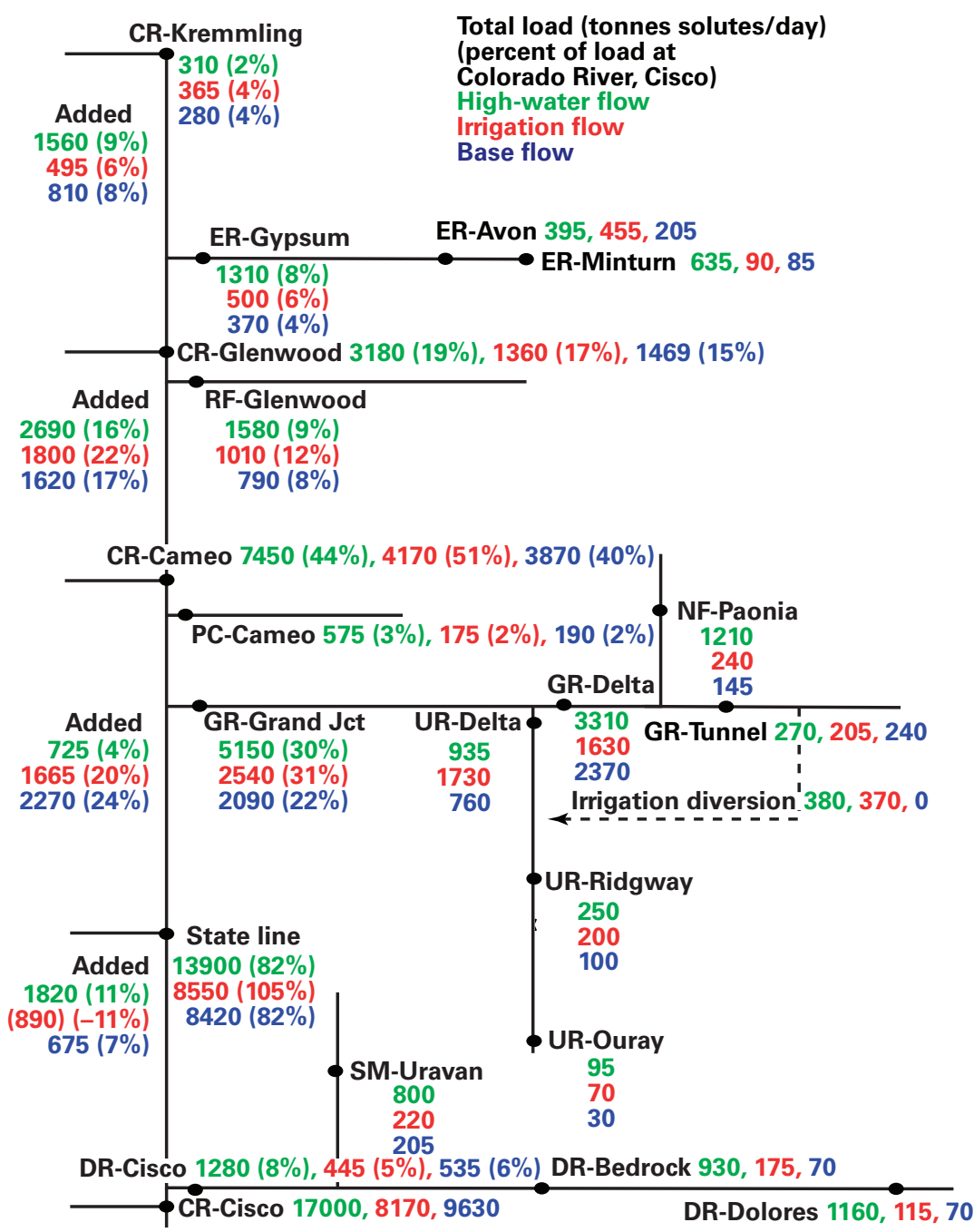

Figure 3. Schematic of total solute loads (tonnes solutes/day) during high-water, irrigation, and base flows (not to scale). Also included are loads from irrigation diversion through the Gunnison Tunnel into the Uncompahgre watershed (dashed line) and percent of the Colorado River load for lowermost tributary stations. "Added" values are loads acquired between stations along the Colorado River not attributable to measured loads in tributaries sampled. CR, Colorado River; ER, Eagle River; RF, Roaring Fork River; PC, Plateau Creek; GR, Gunnison River; NF, North Fork of the Gunnison River; UR, Uncompahgre River; SM, San Miguel River; DR, Dolores River.

some cases, however, loads vary in a more complex manner because concentrations in the water actually change as stream flow conditions change (for example, concentrations related to snow-melt runoff during high-water flow versus those related to ground-water discharge during base flow).

\section{Piper Diagrams}

Piper diagrams, which are used to define water type in a standard format, are shown in figure 4 . The blue line on these plots tracks the evolution of the upper Colorado River from

\footnotetext{
${ }^{4}$ Specific water types are defined as having at least 50 percent of the cation and anion on a milliequivalent (meq) basis. Mixed water types are those with no cation and/or anion that are $>50$ percent on a meq basis.
}

its headwater station at Kremmling to the farthest downstream station sampled at Cisco. The major cation ( $>50$ percent on meq basis) in water during high-water flow conditions is $\mathrm{Ca}$ (fig. 4A); the major anion is $\mathrm{HCO}_{3}$ in all but four samples where $\mathrm{SO}_{4}$ is the dominant anion. Therefore, most of these samples during high water are calcium-bicarbonate water except for the four calcium sulfate waters in the Uncompahgre River and the lowermost Gunnison. ${ }^{4}$ The two lowermost Colorado River samples plot just outside the calcium bicarbonate water field and are technically a mixed-water type.

During irrigation-flow conditions, all headwater samples are calcium bicarbonate water, except for the headwater of the Uncompahgre River (fig. 4B). All water in the Uncompahgre River, water in the Gunnison River below its headwater stations, and water at the San Miguel River station 

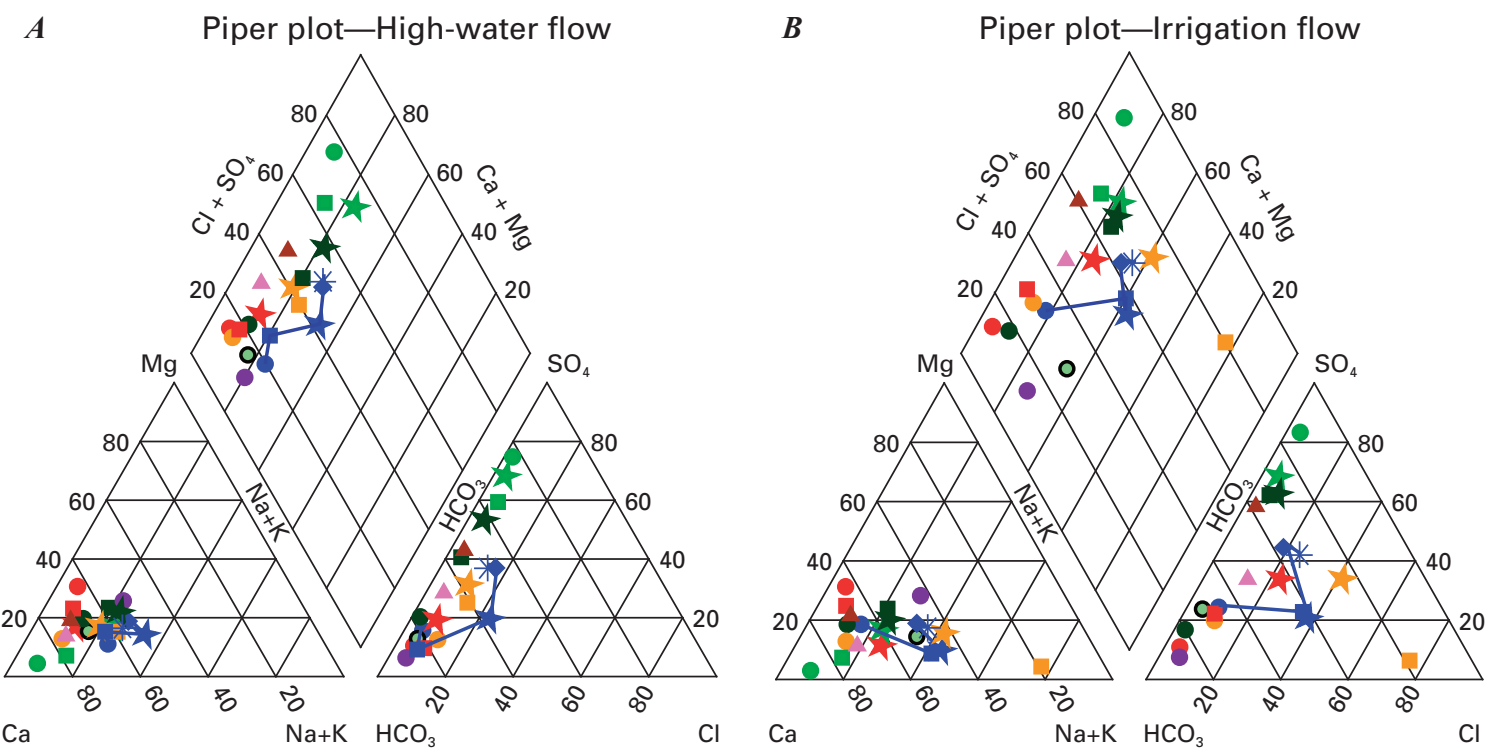

C Piper plot-Base flow

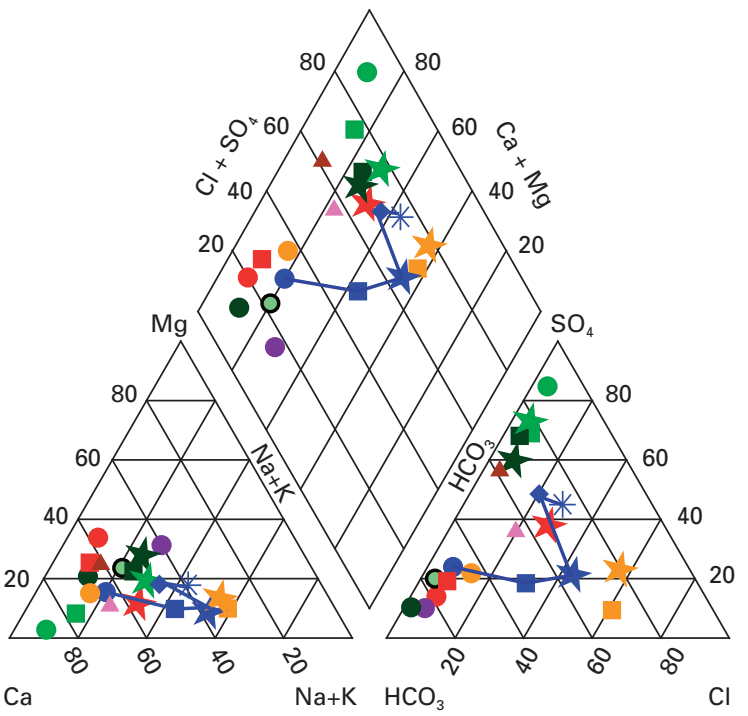

\begin{tabular}{ll}
\multicolumn{2}{c}{ EXPLANATION } \\
CR-Kremmling & UR-Ouray \\
ER-Minturn & UR-Ridgway \\
ER-Avon & UR-Delta \\
At ER-Gypsum & CR-Golo.-Utah \\
- CR-Glenwood Spg. & DR-Dolores \\
A RF-Glenwood Spg. & DR-Bedrock \\
- CR-Cameo & DR-Cisco \\
PC-Cameo & CR-Cisco \\
O GR-tunnel &
\end{tabular}

Figure 4. Piper plots for water at all stations sampled in this study during $(A)$ high-water flow, $(B)$ irrigation flow, and (C) base flow. Data are plotted on a milliequivalent basis. CR, Colorado River; ER, Eagle River; RF, Roaring Fork River; PC, Plateau Creek; GR, Gunnison River; UR, Uncompahgre River; SM, San Miguel River; DR, Dolores River.

are of a calcium sulfate type. The Dolores River water at Bedrock is a sodium chloride type, whereas all other waters are of a mixed type. All Colorado River water below its headwater station is a mixed type; however, at the ColoradoUtah State line and at Cisco, the water approaches the $\mathrm{SO}_{4}$ field.

During base-flow conditions, headwater samples remain calcium bicarbonate water, except at the Uncompahgre River headwater station (fig. 4C). All of the Uncompahgre River and the San Miguel River stations remain calcium sulfate water. The Dolores River at Bedrock and Cisco is sodium chloride water. Water at all other stations is of a mixed type. The largest change in water type in the Colorado River is at Glenwood Springs, where the water type moves toward the $\mathrm{Cl}$ field and is very similar to Colorado River water at Cameo.

\section{Geochemistry at Stations Along Tributary Watersheds to the Upper Colorado River Above Cisco, Utah}

The following discussion of individual tributary results has been organized by watershed. Watersheds for each tributary, as well as those for the upper Colorado River within the study area, are indexed with a number in the map in figure 5. Geologic descriptions of these watersheds were taken from Warner and others (1985), Hintz and others (2000), and Day and others (1999). Estimates for the distance of each confluence considered in our study from the uppermost Colorado River sample at Kremmling are in table 2 . The data presented herein characterize nearly $350 \mathrm{~km}$ of the upper Colorado River. 


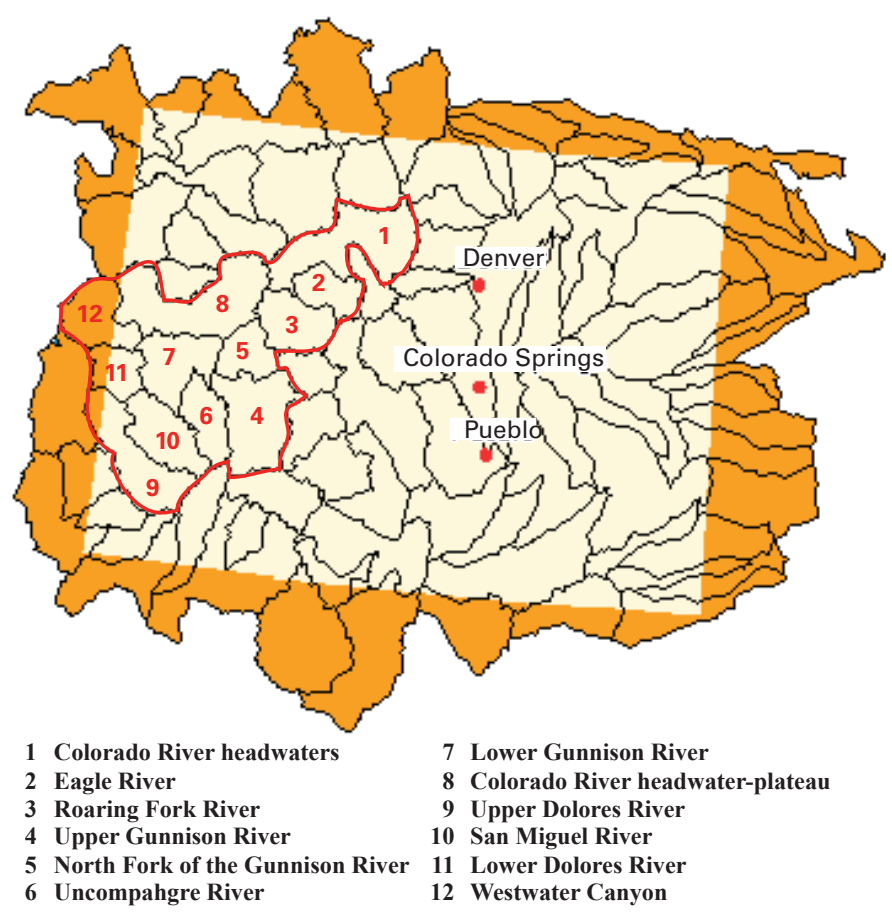

Figure 5. Index map for watersheds considered in this study (numbered 1 to 12). This map and those for watersheds listed were downloaded from http://www.epa.gov/surf/.

Table 2. Approximate distances of major tributary confluences on the Colorado River considered in this study downstream from the Kremmling station.

\begin{tabular}{lc}
\hline \multicolumn{1}{c}{ Confluence } & $\begin{array}{c}\text { Distance } \\
\text { (km) }\end{array}$ \\
\hline Eagle River & 80 \\
Roaring Fork River & 112 \\
Plateau Creek & 215 \\
Gunnison River & 250 \\
Dolores River & 345 \\
\hline
\end{tabular}

\section{Eagle River}

Three stations were sampled within the Eagle River watershed (fig. 6) - near or at Minturn, Avon, and Gypsum. The flow of the Eagle River is not controlled by any major reservoirs. The rocks upstream from Minturn are metamorphic and carbonate rocks, some mineralized. Between Minturn and Avon, rocks are predominately sedimentary and include carbonates, sandstones, and shales. Below Avon, the Eagle River crosses large expanses of Pennsylvanian Eagle Valley Evaporite composed of thick salt beds (mostly gypsum at the surface with halite at depth) and some sandstone and shale. Starting along the tributary at Vail and continuing downstream past Avon, the river valley is heavily developed with recreational communities. Some historic mining of base and precious metal ore occurred in the upper reaches of this watershed, and gypsum (Eagle Valley Evaporite) and volcanic cinder are mined in the lower portion of the river valley.

\section{Eagle River Near Minturn, Colorado}

The conductivity at this station is low (less than $140 \mu \mathrm{S} / \mathrm{cm}$ ), and the water is a calcium bicarbonate type (fig. 4; table 3). Waters at this station contain relatively high concentrations of dissolved and available $\mathrm{Fe}, \mathrm{Mn}$, and $\mathrm{Zn}$ (table AI-3). These metal concentrations, which are related to historic mining in the headwater area (for example, Eagle mine), decrease downstream. The $\mathrm{Ca}: \mathrm{SO}_{4}$ ratio (table 3 ) at this station during high-water flow is consistent with most Ca being derived from the dissolution of minerals other than gypsum and the $\mathrm{Na}: \mathrm{Cl}$ ratio with halite dissolution. Exposure of the Eagle Valley Evaporite does not occur in the watershed at or upstream from this station. Although speculative, the application of deicer mixtures that contain halite could explain the ratio during high-water flow, as much of the upstream watershed is in areas where winter highway maintenance includes deicing roads along the stream. Deicer contamination was also suggested by a concentration in shallow aquifers in the urban corridor on the east side of the continental divide (Flynn, 2003). During irrigation and base-flow conditions (periods when deicer is not being applied to the roads), the $\mathrm{Na}: \mathrm{Cl}$ ratio increases slightly suggesting another source of sodium, and the $\mathrm{Ca}: \mathrm{SO}_{4}$ ratio decreases suggesting an additional source of sulfate. Isotopes for the dissolved sulfate (fig. 7) are relatively constant during irrigation and base flow (the sulfate concentration at high-water flow was too low for isotope measurement). Isotope values are consistent with sulfate derived from oxidation of sulfide ores (fig. 7) predominately with atmospheric oxygen (Taylor and Wheeler, 1994).

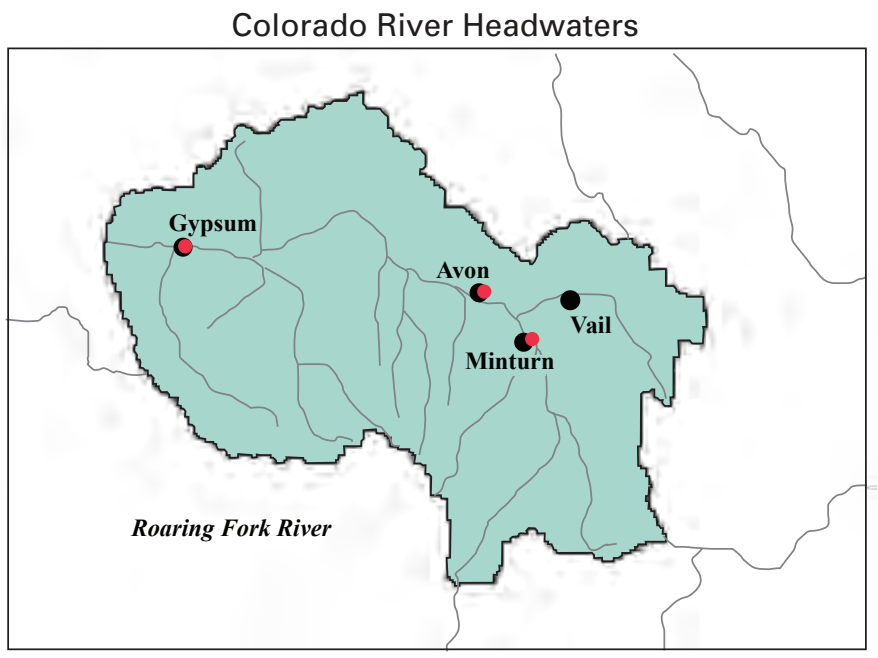

Figure 6. Map of the Eagle River watershed (no. 2 on fig. 5), showing adjacent sampled watersheds, Minturn (the uppermost stream station), Avon (6 km from Minturn), and Gypsum (50 km from Minturn); the latter is the lowermost station in the watershed. Red dots, stations sampled. This and all subsequent watershed maps modified from those at $h$ ttp://www.epa.gov/surf/. 
Table 3. Summary of geochemical parameters for the Eagle River at Minturn.

[HW, high-water flow; IRR, irrigation flow; BF, base flow; CR, Colorado River]

\begin{tabular}{lccc}
\hline \multicolumn{1}{c}{$\begin{array}{c}\text { Eagle River } \\
\text { at Minturn }\end{array}$} & HW & IRR & BF \\
\hline Charge balance (percent) & -9 & 2 & 1 \\
Conductivity $(\mu \mathrm{S} / \mathrm{cm})$ & 105 & 140 & 110 \\
Water type & $\mathrm{Ca}-\mathrm{HCO}_{3}$ & $\mathrm{Ca}-\mathrm{HCO}_{3}$ & $\mathrm{Ca}-\mathrm{HCO}_{3}$ \\
Load (tonnes solutes/day) & 115 & 25 & 18 \\
Percent CR load at Cisco & 1 & $<1$ & $<1$ \\
$\mathrm{Ca}: \mathrm{SO}_{4}$ (molar basis) & 5.7 & 4.1 & 3.1 \\
$\mathrm{Na} \mathrm{Cl}$ (molar basis) & 1.1 & 1.4 & 1.2 \\
Evaporation & no & no & no \\
$\mathrm{SO}_{4}$ source & mineralization & mineralization & mineralization \\
\hline
\end{tabular}

\section{Eagle River at Avon, Colorado}

During high-water flow, the water at this station has a composition very similar to that at Minturn (fig. 4); however, the load at Avon increases by 3.5 times that at Minturn because the flow increases by a similar amount (table 4). During irrigation conditions, the $\mathrm{Ca}: \mathrm{SO}_{4}$ ratio decreases (table 4 ) as the $\mathrm{SO}_{4}$ concentration more than doubles (although still a small concentration), whereas concentrations of the other major elements change only slightly. The source of the additional sulfate is isotopically heavier than that at Minturn (fig. 7), suggesting that some dissolution of Pennsylvanian evaporites $\left(\delta^{34} \mathrm{~S}_{\mathrm{SO} 4}=14 \%\right.$ and $\delta^{18} \mathrm{O}_{\mathrm{SO} 4}=11 \%$; table AIII-2) is contributing to the salt load. The Na:Cl ratios during all flow conditions are near one, consistent with dissolution of halite in the Eagle Valley Evaporite.

\section{Eagle River at Gypsum, Colorado}

The conductivity of water at this station is between 2 and 2.5 times that at Avon under all flow conditions (table 5). During high-water flow, the river water is a calcium bicarbonate type. During irrigation and base flow, a higher proportion of sulfate changes the water to a mixed anion type with $\mathrm{Ca}$ continuing to be the predominant cation (fig. 4). The $\mathrm{Ca}: \mathrm{SO}_{4}$ ratios (table 5) are lower than at Avon and are highest during high-water flow. The dissolution of gypsum in the Eagle Valley Evaporite contributes a greater proportion of sulfate during irrigation and base-flow conditions as evident from the dramatic rise in the $\delta^{34} \mathrm{~S}_{\mathrm{SO} 4}$ and $\delta^{18} \mathrm{O}_{\mathrm{SO} 4}$ values (fig. 7).

\section{Geochemical Evolution Along the Eagle River}

The composition of the Eagle River between Minturn and Avon changes little (fig. 4); however, there is an increase in sulfate proportion at Gypsum, especially during irrigation and base flow. The increased flow during high water increases the load of the river by over three times that during irrigation or base flow. Between Avon and Gypsum, $\mathrm{HCO}_{3(\mathrm{aq})}$ and $\mathrm{SO}_{4(\mathrm{aq})}$ concentrations increase as well as concentrations of many of the "available" elements (table AI-3). "Available" element concentrations significantly influence loads during high flow as soil and fine rock particles are carried in the more turbulent runoff. These particles consist of detrital components rich in resistate minerals containing $\mathrm{Ba}$, rare earths, $\mathrm{Sc}, \mathrm{Si}$, $\mathrm{Ti}$, and in oxides and oxide coatings rich in $\mathrm{Al}, \mathrm{Fe}, \mathrm{Mn}$, and adsorbed metals such as $\mathrm{Cd}, \mathrm{Co}, \mathrm{Cr}$,

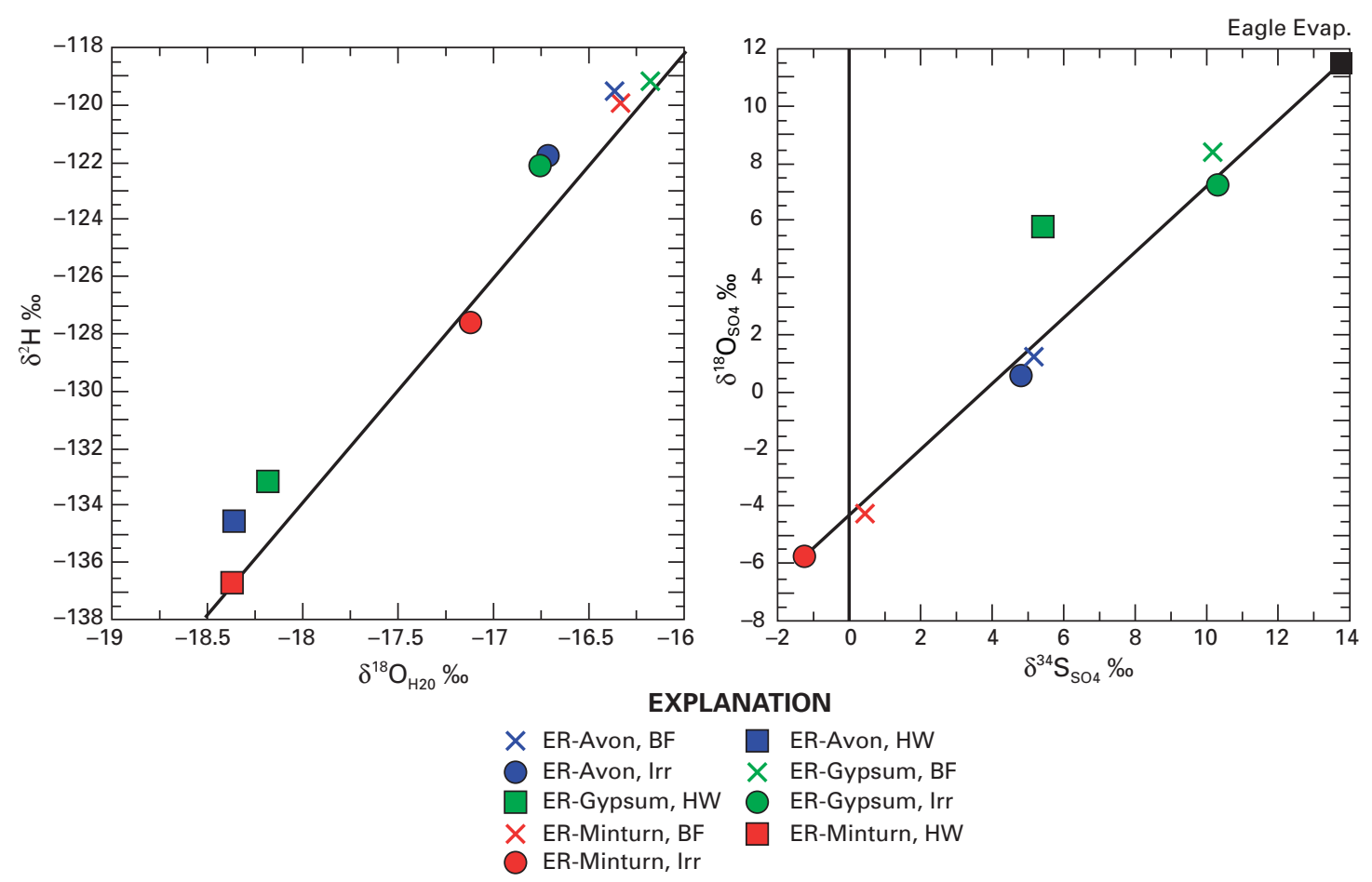

Figure 7. Cross plots showing relations between isotopic composition of $\delta^{2} \mathrm{H}$ and $\delta^{18} \mathrm{O}$ of water and the GMWL (left) and $\delta^{18} 0$ and $\delta^{34} S$ of dissolved sulfate in the Eagle River (ER) at three sampling stations during three flow seasons (right). HW, high-water flow; Irr, irrigation flow; BF, base flow. Hydrogen and oxygen isotopes measured relative to $\mathrm{V}$-SMOW and sulfur isotopes relative to $\mathrm{V}$-CDT. 
Table 4. Summary of geochemical parameters for the Eagle River at Avon.

[HW, high-water flow; IRR, irrigation flow; BF, base flow; CR, Colorado River]

\begin{tabular}{lccc}
\hline \multicolumn{1}{c}{ Eagle River at Avon } & HW & IRR & BF \\
\hline Charge balance (percent) & 3 & 2 & 17 \\
Conductivity $(\mu \mathrm{S} / \mathrm{cm})$ & 100 & 130 & 190 \\
Water type & $\mathrm{Ca}-\mathrm{HCO}_{3}$ & $\mathrm{Ca}-\mathrm{HCO}_{3}$ & $\mathrm{Ca}-\mathrm{HCO}_{3}$ \\
Load (tonnes solutes/day) & 395 & 105 & 100 \\
Percent CR load at Cisco & 2 & 1 & 1 \\
$\mathrm{Ca}: \mathrm{SO}_{4}$ (molar basis) & 4.8 & 2.4 & 1.9 \\
$\mathrm{Na}: \mathrm{Cl}$ (molar basis) & 0.86 & 0.98 & 0.96 \\
Evaporation & no & no & no \\
$\mathrm{SO}_{4}$ source & mineralization & mineralization mineralization \\
& + evaporites & + evaporites & + evaporites \\
\hline
\end{tabular}

Table 5. Summary of geochemical parameters for the Eagle River at Gypsum.

[HW, high-water flow; IRR, irrigation flow; BF, base flow; CR, Colorado River]

\begin{tabular}{lccc}
\hline \multicolumn{1}{c}{ Eagle River at Gypsum } & HW & IRR & BF \\
\hline Charge balance (percent) & 9 & -2 & -3 \\
Conductivity $(\mu \mathrm{S} / \mathrm{cm})$ & 190 & 360 & 555 \\
Water type & $\mathrm{Ca}-\mathrm{HCO}_{3}$ & mixed & mixed \\
Load (tonnes solutes/day) & 1,310 & 500 & 370 \\
Percent CR load at Cisco & 8 & 6 & 4 \\
$\mathrm{Ca}: \mathrm{SO}_{4}$ (molar basis) & 2.6 & 1.6 & 1.4 \\
$\mathrm{Na} \mathrm{Cl}$ (molar basis) & 1.3 & 1.2 & 1.1 \\
Evaporation & no & no & no \\
Dominant $\mathrm{SO}_{4}$ source & evaporites & evaporites & evaporites \\
\hline
\end{tabular}

$\mathrm{Cu}, \mathrm{Ni}, \mathrm{V}$, and $\mathrm{Zn}$. During base-flow conditions, significant concentrations of evaporite-related elements such as those from halite $(\mathrm{Na}$ and $\mathrm{Cl})$ and from gypsum $\left(\mathrm{Ca}, \mathrm{Sr}\right.$, and $\left.\mathrm{SO}_{4}\right)$ influence the load primarily through discharge of ground water that has flowed through Eagle Valley Evaporite.

The $\delta^{2} \mathrm{H}$ and $\delta^{18} \mathrm{O}$ values of the Eagle River water for all flow conditions fall on or very close to the global meteoric water line (GMWL; represented by $\delta^{2} \mathrm{H} \%_{0}=8 \delta^{18} \mathrm{O} \%_{0}+10 \%$ relative to SMOW; Craig, 1961) (fig. 7). Little evaporation of the water takes place along the river, and the variation in position along the water line among flow conditions reflects changing proportions of water derived from snowmelt during high flow (isotopically lighter values ${ }^{5}$ ) to ground-water discharge during base flow (isotopically heavier values).

Spatial and temporal variation in the sulfate isotopic composition among the three stations along the Eagle River results in a line, except for the Eagle River at Gypsum during high-water flow (fig. 7). The evolution of the sulfate derived principally from sulfide oxidation is distinct from that derived from Eagle Valley Evaporite, and mixing of these two sources is evident from this linear relation. It is possible that during high-water flow, an additional source contributes to the sulfate, causing the isotopic

${ }^{5}$ In this report, isotopically lighter refers to a depletion in the heavier isotope $\left({ }^{2} \mathrm{H},{ }^{18} \mathrm{O}\right.$, or $\left.{ }^{34} \mathrm{~S}\right)$, resulting in a smaller $\delta$ value relative to the appropriate standard, and conversely, isotopically heavier refers to an enrichment in the heavier isotope, resulting in a larger $\delta$ value. composition to deviate from the linear trend. Unfortunately, sulfate concentrations were too low in the samples collected from the Eagle River at Minturn and Avon during high water to analyze for isotopes to confirm this additional source. Isotope mass-balance calculations indicate that the source of the dissolved sulfate at Avon during irrigation and base flow is 60 percent from the upstream source (presumably sulfide oxidation that would be consistent with the lighter isotope compositions) and 40 percent from evaporites. At Gypsum, 75 percent of the sulfate is from evaporites and 25 percent from an upstream source.

\section{Roaring Fork River at Glenwood Springs, Colorado}

Flow in the Roaring Fork River (fig. 8) is regulated by Reudi Reservoir east of the town of Basalt. The geology in this watershed is mostly igneous rocks in the headwaters, Pennsylvanian and Permian rocks, including evaporites, and Cretaceous Mancos Shale in the lower portions of the watershed. The water type at this station is calcium bicarbonate during high-water and irrigation flow and a mixed type with increasing sulfate and chloride contributions during base flow (fig. 4, table 6). During irrigation and base flow, the Ca: $\mathrm{SO}_{4}$ and $\mathrm{Na}: \mathrm{Cl}$ ratios (table 6) look very similar to those in the Colorado River above Glenwood Springs. During high water, both ratios are higher, likely due to an increased contribution from igneous rocks in the headwaters during runoff $\left(\mathrm{HCO}_{3}\right.$ contribution is larger as well). The sulfate isotope data (see fig. 16 in Geochemical Evolution of the Colorado River Above Cisco) fall on a mixing trend of sulfate derived from Eagle Valley Evaporite and likely crystalline rocks upstream. Isotope measurements show that Mancos Shale contributes little sulfate to this river.

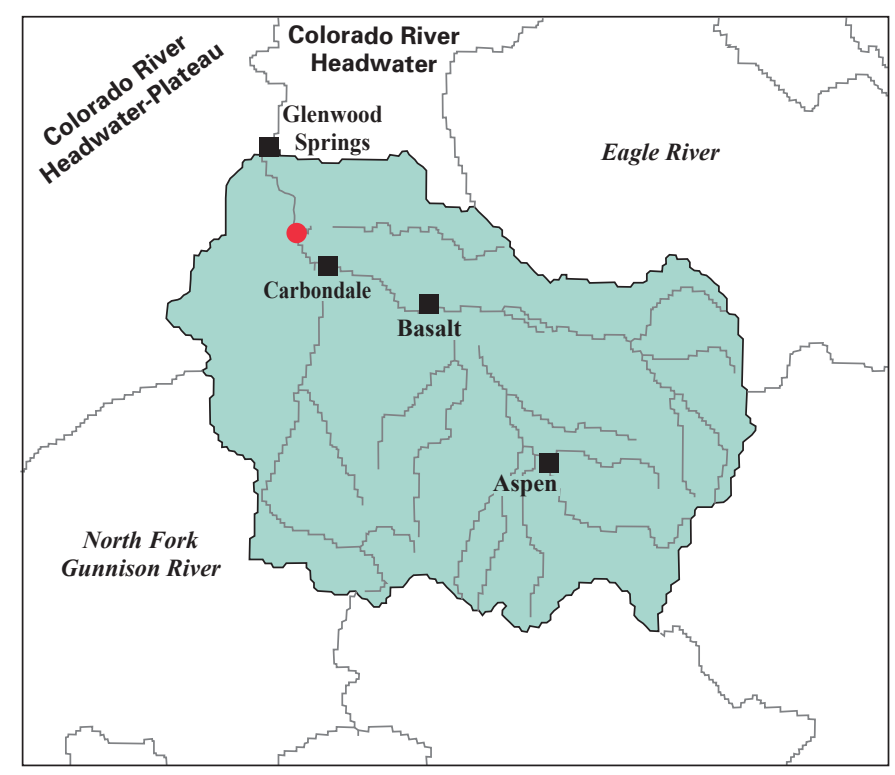

Figure 8. Map of Roaring Fork River watershed (no. 3 on fig. 5) showing adjacent sampled watersheds. Red dot, station sampled. Map modified from http://www.epa.gov/surf/. 
Table 6. Summary of geochemical parameters for Roaring Fork River at Glenwood Springs.

[HW, high-water flow; IRR, irrigation flow; BF, base flow; CR, Colorado River]

\begin{tabular}{lccc}
\hline $\begin{array}{c}\text { Roaring Fork River } \\
\text { at Glenwood Springs }\end{array}$ & HW & IRR & BF \\
\hline Charge balance (percent) & 0.4 & -0.6 & -3 \\
Conductivity $(\mu \mathrm{S} / \mathrm{cm})$ & 250 & 440 & 600 \\
Water type & $\mathrm{Ca}-\mathrm{HCO}_{3}$ & $\mathrm{Ca}-\mathrm{HCO}_{3}$ & mixed \\
Load (tonnes solutes/day) & 1,580 & 1,010 & 790 \\
Percent CR load at Cisco & 9 & 12 & 8 \\
$\mathrm{Ca}: \mathrm{SO}_{4}$ (molar basis) & 2.2 & 1.7 & 1.6 \\
$\mathrm{Na}: \mathrm{Cl}$ (molar basis) & 1.7 & 1.3 & 1.2 \\
Evaporation & no & no & no \\
Dominant $\mathrm{SO}_{4}$ source & evaporites & evaporites & evaporites \\
\hline
\end{tabular}

\section{Gunnison River}

The Gunnison River and its tributaries flow through six watersheds. Seven stations within four of these watersheds were sampled (fig. 9). The flow in the Gunnison River is controlled by dams on Taylor River, the mainstream Gunnison River, Muddy Creek, and Uncompahgre River.

\section{Uncompahgre River}

\section{Uncompahgre River Near Ouray, Colorado}

The flow of the water at this station (fig. 9) is not controlled by reservoirs upstream. The geology within the watershed upstream is volcanic rock that is mineralized in places. The conductivities at this station are higher than any others in the headwater group and waters are of a different type (calcium sulfate instead of calcium bicarbonate; fig. 4, table 7). This difference likely reflects the intense mining in this area related to Tertiary mineralization in the watershed. The volcanic rocks along the Uncompahgre River upstream from this station are highly altered with large mining reclamation sites in and along the drainage. Oxidation of sulfide ores and dissolution of primary and secondary gypsum in ores related to these deposits and alteration zones are likely the source of sulfate (see isotope discussion below). Water at this station also contains relatively high concentrations of dissolved $\mathrm{Cd}, \mathrm{Co}, \mathrm{Cu}, \mathrm{Ni}$, and $\mathrm{Zn}$ (only $\mathrm{Cd}$ and $\mathrm{Zn}$ exceed the chronic freshwater maximum contaminant level of $0.25 \mu \mathrm{g} / \mathrm{L}$ and $120 \mu \mathrm{g} / \mathrm{L}$, respectively; EPA, 2006), as well as high concentrations of available base-metal concentrations $\left(\mathrm{Cu}_{\text {(avail) }}\right.$, $\mathrm{Fe}_{\text {(avail), }}, \mathrm{Mn}_{\text {(avail) }}, \mathrm{Pb}_{\text {(avail), }}$, and $\left.\mathrm{Zn}_{\text {(avail) }}\right)$. The metal concentrations decrease with distance downstream and are not anomalous in the Gunnison River downstream from its confluence with the Uncompahgre. The $\mathrm{Na}: \mathrm{Cl}$ ratios (table 7) are greater than one indicating that sodium is probably being derived from the volcanic rocks. The $\mathrm{Ca}: \mathrm{SO}_{4}$ ratios of near one are consistent with sulfate being derived predominately from primary gypsum and/or secondary gypsum that formed following oxidation of sulfides. Pyrite in mineralized areas across the divide from the Uncompahgre headwaters has an average $\delta^{34} \mathrm{~S}_{\mathrm{py}}$ of
-3 per mil, and cogenetic gypsum has an average of 16 per mil (Nordstrom and others, 2007) compared to the 2.9 per mil in sulfate at our station during high water (fig. 10). From high water to irrigation flow to base flow, there is a small, but systematic shift to isotopically heavier sulfate $\left(\delta^{34} \mathrm{~S}_{\mathrm{SO} 4}=2.9\right.$ to 4.1 to $6.8 \%$, respectively), accompanied by a similar small increase in $\delta^{18} \mathrm{O}_{\mathrm{SO} 4}(-4.3$ to -3.3 to $-1.6 \%$ ). These data suggest that the sulfate in the Uncompahgre River at Ouray could be derived from both sulfide oxidation and primary gypsum dissolution upstream, with gypsum dissolution becoming more important during low stream flow. The isotope values at the station may also reflect the input of sulfate in Canyon Creek, an upstream tributary, which has a $\delta^{34} \mathrm{~S}_{\mathrm{SO} 4}$ of $7.3 \%$ and a $\delta^{18} \mathrm{O}_{\mathrm{SO} 4}$ value of $-1.6 \%$ (Tuttle, unpub. data). A change in the proportion of this tributary contribution could explain the shift in isotope values among flow conditions. Unfortunately, we do not have adequate data to test these two hypotheses.

\section{Uncompahgre River Near Ridgway, Colorado}

The flow of the Uncompahgre River at this station is not controlled by reservoirs. The geology along this reach of the Uncompahgre River consists predominantly of Tertiary volcanics and Permian, Triassic, and Jurassic sedimentary rocks. The marine, Cretaceous age Mancos Shale crops out at the downstream end of this stretch of the river. The Ca: $\mathrm{SO}_{4}$ ratio is near one (table 8), suggesting that the source of these solutes is gypsum, and the $\mathrm{Na}: \mathrm{Cl}$ ratios are three or greater, indicating that the sodium likely is sourced from the volcanic rocks upstream. Ratios are similar under different flow conditions, suggesting that similar sources of solutes are likely. The isotope values for dissolved sulfate (fig. 10) are essentially the same from high-water flow to irrigation flow and are somewhat lighter than those at Ouray, suggesting a new source of sulfate, although the dominant source is still the same as at Ouray. This new source of sulfate is the Mancos Shale, which contains sulfate with negative $\delta^{34} \mathrm{~S}_{\mathrm{SO} 4}$ values (average of $-21 \%$; Tuttle, unpub. data). During base flow, the isotopes in the sulfate evolve to heavier values as seen in the Ouray isotopes, reflecting either the change from sulfide to primary gypsum as the dominant source in the headwaters or a change in the proportion of tributary flow upstream.

\section{Uncompahgre River at Delta, Colorado}

The flow of the Uncompahgre River at Delta is controlled by a reservoir upstream (below the station near Ridgway and just above the town of Colona), and, during high-water flow and irrigation conditions, by contributions of water diverted for irrigation from the Gunnison River just above the tunnel station (see discussion below). The geology in this lower portion of the watershed is dominated by the Cretaceous Dakota Sandstone and Mancos Shale. Selenium concentrations exceed the Colorado State freshwater chronic standard of $4.6 \mu \mathrm{g} / \mathrm{L}$ (CDPHE, 2003) during all flow regimes. The $\mathrm{Ca}: \mathrm{SO}_{4}$ ratios 
Uncompahgre River Watershed (6)

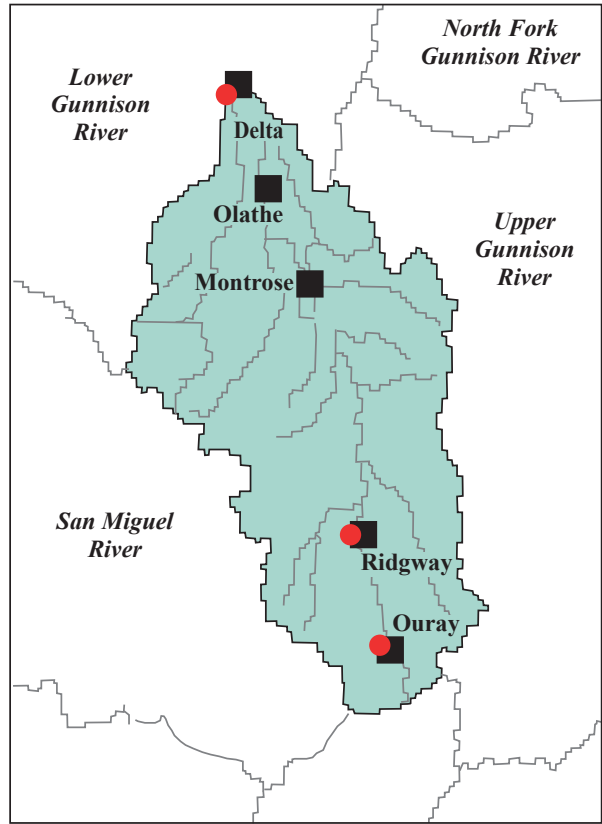

Lower Gunnison River Watershed (7)

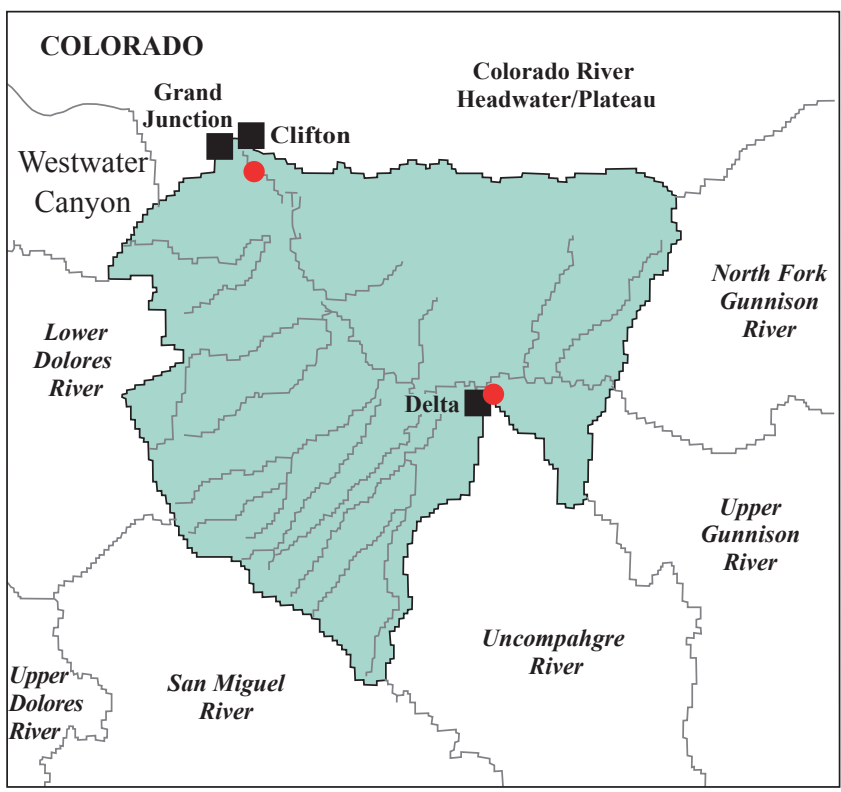

Upper Gunnison River Watershed (4)

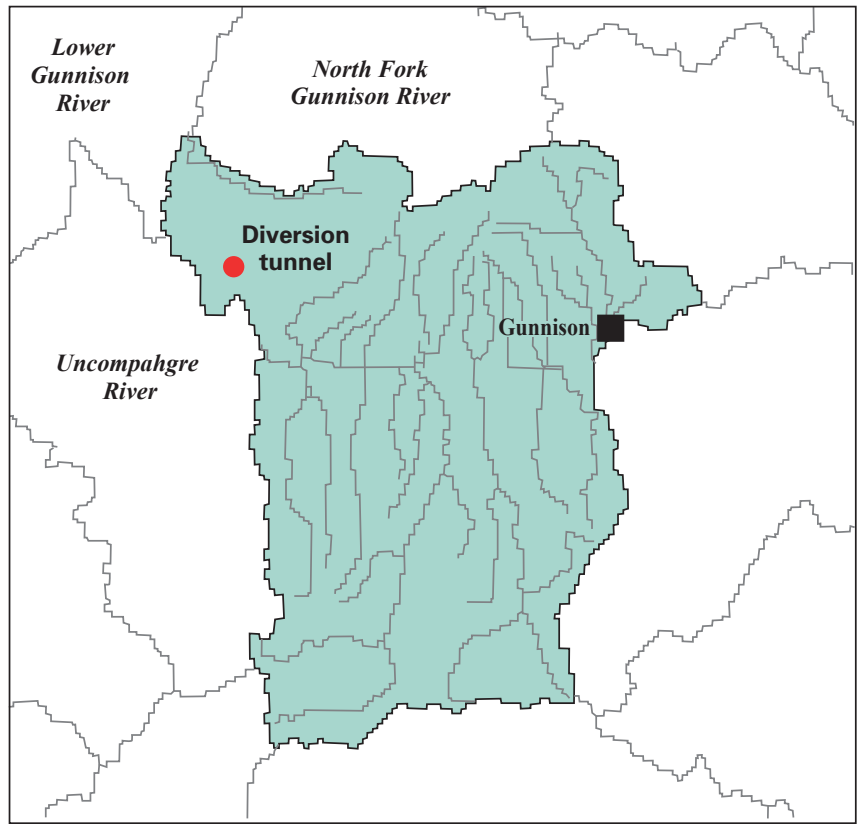

North Fork Gunnison River Watershed (5)

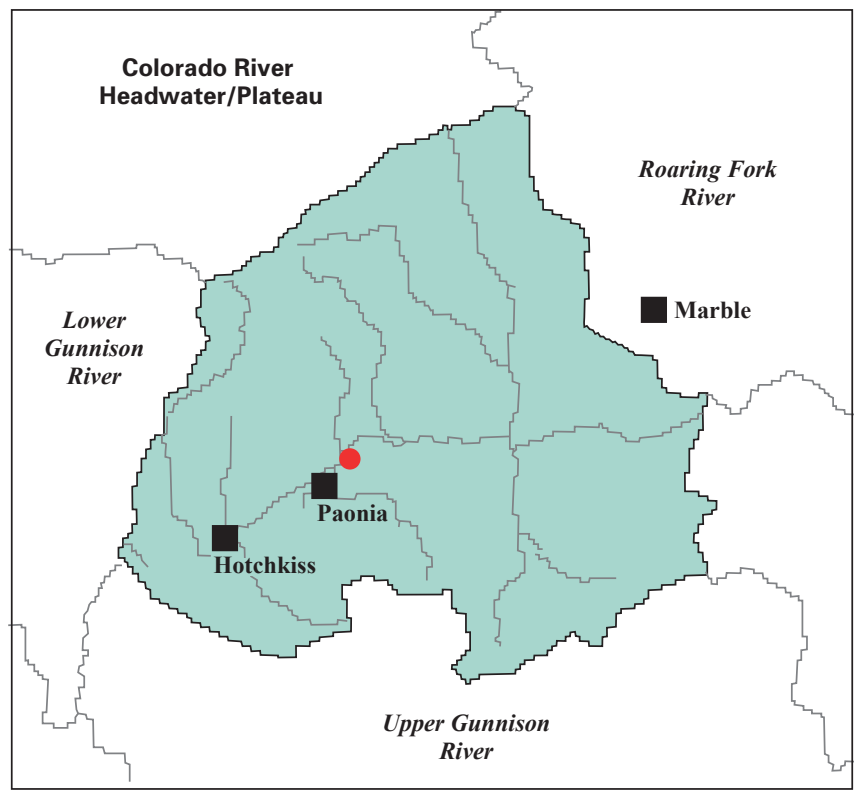

Figure 9. Maps of upper Gunnison River (no. 4), North Fork of the Gunnison River (no. 5), Uncompahgre River (no. 6), and lower Gunnison River (no. 7) watersheds (numbers refer to locations shown on fig. 5) showing adjacent sampled watersheds. The farthest upstream sample on the Gunnison River (Tunnel station) is 80 miles above confluence with the Colorado River (CR). The Paonia station is in the North Fork of the Gunnison watershed and three stations (Ouray, Ridgeway, and Delta stations) are in the Uncompahgre watershed. Red dots, stations sampled. Maps modified from http://www.epa.gov/surf/.

are all less than one, and at base flow, fall to 0.7 (table 9). The $\mathrm{Na}: \mathrm{Cl}$ ratios are high and, together with the low $\mathrm{Ca}: \mathrm{SO}_{4}$ ratios, suggest that dissolution of sodium sulfate efflorescent salts contributes to these solutes. These highly soluble salts are common on and in Mancos soils and form during weathering when $\mathrm{CaSO}_{4}$ dissolves and $\mathrm{Ca}$ exchanges for $\mathrm{Na}$ on the marine clays (this process in the Mancos Shale is described in Tuttle and others, 2005). Although Na-salt dissolution plays a role in solute loading at this station, it does not alter the water from a predominantly calcium sulfate type. Isotopes of sulfate $(-18$ to $-15 \%$; fig. 10) substantiate that the dominant source of sulfate is oxidation products from sulfides in the Mancos Shale during weathering. Evaporation of irrigation water is reflected in the water isotopes (fig. 10). 
Table 7. Summary of geochemical parameters for the Uncompahgre River near Ouray.

[HW, high-water flow; IRR, irrigation flow; BF, base flow; CR, Colorado River]

\begin{tabular}{lccc}
\hline $\begin{array}{c}\text { Uncompahgre River } \\
\text { near Ouray }\end{array}$ & HW & IRR & BF \\
\hline Charge balance (percent) & 21 & 18 & 4 \\
Conductivity ( $\mu \mathrm{S} / \mathrm{cm})$ & 235 & 395 & 625 \\
Water type & $\mathrm{Ca}^{-\mathrm{SO}_{4}}$ & $\mathrm{Ca}-\mathrm{SO}_{4}$ & $\mathrm{Ca}_{4}-\mathrm{SO}_{4}$ \\
Load (tonnes solutes/day) & 96 & 72 & 31 \\
Percent CR load at Cisco & 1 & 1 & $<1$ \\
$\mathrm{Ca}: \mathrm{SO}_{4}$ (molar basis) & 1.0 & 0.94 & 0.89 \\
$\mathrm{Na} \mathrm{Cl}$ (molar basis) & 2.4 & 2.4 & 2.5 \\
Evaporation & no & no & no \\
Dominant $\mathrm{SO}_{4}$ source & mineralization mineralization & mineralization \\
\hline
\end{tabular}

\section{Geochemical Evolution Along the Uncompahgre River}

The water in the Uncompahgre River is calcium sulfate water throughout the entire year (fig. 4). During high water, concentrations of dissolved major anions and cations increase from the headwaters (Ouray) to the confluence with the Gunnison River whereas most trace metals decrease. Available $\mathrm{Fe}, \mathrm{SiO}_{2}$, and $\mathrm{Ti}$ increase downstream (table $\mathrm{AI}-3$ ), but few available metal concentrations mirror this trend, suggesting that the metals are not adsorbed to iron, silica, or titanium oxides being carried in the river. Between Ridgway and Delta, available trace metals $(\mathrm{Co}, \mathrm{Pb}$, rare earths, $\mathrm{Se}$, and $\mathrm{V})$ increase

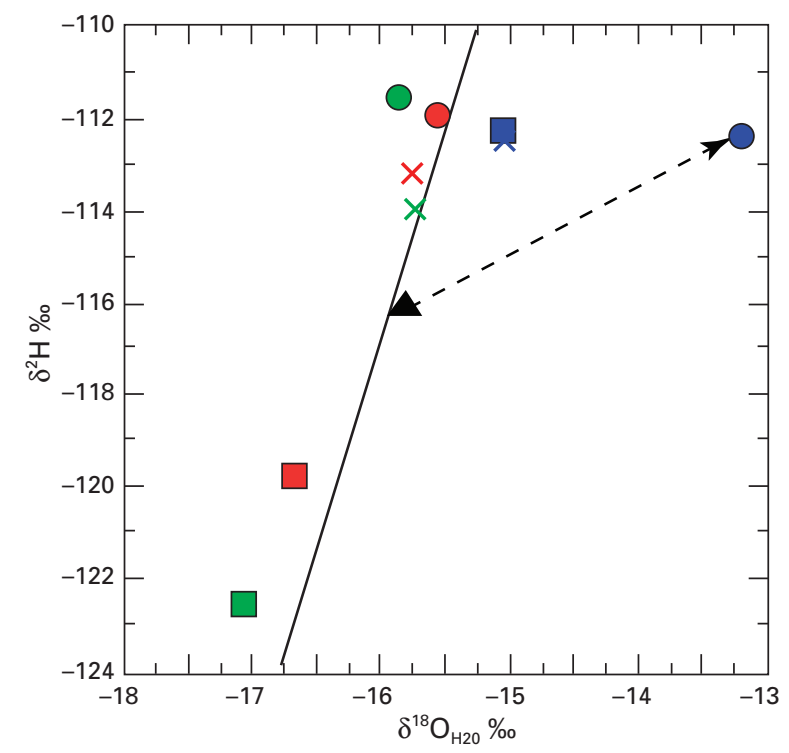

as well as does available $\mathrm{Al}$ and $\mathrm{Mn}$. This relation suggests that the metals are associated with $\mathrm{Al}_{2} \mathrm{O}_{3}$ and $\mathrm{MnO}_{2}$. A similar suite of elements increases or (decreases) from Ouray to Delta during irrigation season with a few exceptions, notably $\mathrm{SO}_{4}$, which only increases from Ridgway to Delta. During base flow, most metals, with the exception of Se and available Fe, decrease as the water flows to Delta. The increase of $\mathrm{SO}_{4}$ between Ridgway and Delta is still evident during this flow period.

Water isotopes (fig. 10) indicate that little evaporation takes place along this reach of the river except between Ridgway and Delta during irrigation flow. The starting isotopic composition of the irrigation water (diversion + reservoir in fig. 10) was estimated with mass-balance calculations using the composition of diversion water (see section on Gunnison River below Gunnison Tunnel) and Uncompahgre River water at Ridgway. The large isotope shift in water in the Uncompahgre River at Delta during the irrigation period is due to return of water that has undergone evaporation during the irrigation process. Positioning along the GMWL for the other data reflects snowmelt runoff versus rain and groundwater discharge. A stream-flow budget (table 10) shows that, during high-water and irrigation flow, only 35 to 55 percent of the water delivered by diversion and stream flow returns to the Uncompahgre River. Although some of the diverted water is lost to consumptive use and some is lost as irrigationreturn to the Gunnison River, much of the water is lost through

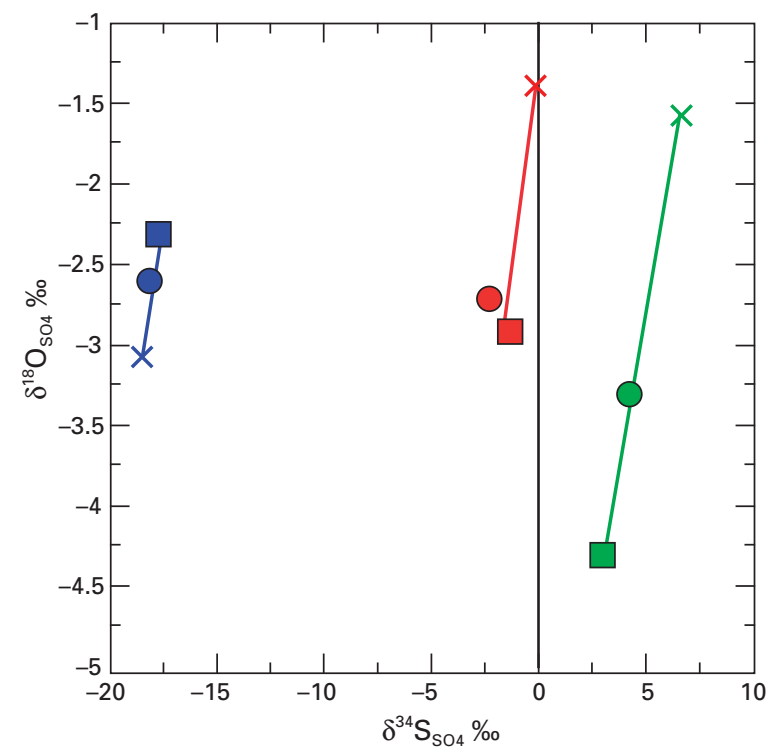

EXPLANATION

\begin{tabular}{|c|c|}
\hline Delta, BF & Ridgway, HW \\
\hline Delta, Irr & Ouray, BF \\
\hline Delta, HW & Ouray, Irr \\
\hline Ridgway, BF & Ouray, HW \\
\hline Ridgway, Irr & $\begin{array}{l}\text { diversion + reservoir } \\
\text { (calculated) }\end{array}$ \\
\hline
\end{tabular}

Figure 10. Isotope data for the Uncompahgre River including water isotopes for the diversion + reservoir water (calculated using isotope mass-balance equations). HW, high-water flow; Irr, irrigation flow; BF, base flow. Hydrogen and oxygen isotopes measured relative to V-SMOW and sulfur isotopes relative to V-CDT. 
Table 8. Summary of geochemical parameters for the Uncompahgre River near Ridgeway.

[HW, high-water flow; IRR, irrigation flow; BF, base flow; CR, Colorado River]

\begin{tabular}{lccc}
\hline $\begin{array}{c}\text { Uncompahgre River } \\
\text { near Ridgway }\end{array}$ & HW & IRR & BF \\
\hline Charge balance (percent) & -0.1 & -2.5 & 4.9 \\
Conductivity $(\mu \mathrm{S} / \mathrm{cm})$ & 420 & 565 & 680 \\
Water type & $\mathrm{Ca}-\mathrm{SO}_{4}$ & $\mathrm{Ca}-\mathrm{SO}_{4}$ & $\mathrm{Ca}-\mathrm{SO}_{4}$ \\
Load (tonnes solutes/day) & 250 & 200 & 100 \\
Percent CR load at Cisco & 1 & 2 & 1 \\
$\mathrm{Ca}: \mathrm{SO}_{4}$ (molar basis) & 1.2 & 1.2 & 0.94 \\
$\mathrm{Na} \mathrm{Cl}$ (molar basis) & 3.0 & 3.4 & 3.7 \\
Evaporation & no & no & no \\
Dominant $\mathrm{SO}_{4}$ source & mineralization & mineralization & mineralization \\
\hline
\end{tabular}

Table 9. Summary of geochemical parameters for the Uncompahgre River at Delta.

[HW, high-water flow; IRR, irrigation flow; BF, base flow; CR, Colorado River]

\begin{tabular}{lccc}
\hline $\begin{array}{c}\text { Uncompahgre River } \\
\text { at Delta }\end{array}$ & HW & IRR & BF \\
\hline Charge balance (percent) & -3 & -3 & 0.9 \\
Conductivity $(\mu \mathrm{S} / \mathrm{cm})$ & 1,070 & 1,150 & 1,530 \\
Water type & $\mathrm{Ca}^{-\mathrm{SO}_{4}}$ & $\mathrm{Ca}-\mathrm{SO}_{4}$ & $\mathrm{Ca}_{4} \mathrm{SO}_{4}$ \\
Load (tonnes solutes/day) & 935 & 1,730 & 760 \\
Percent CR load at Cisco & 6 & 21 & 8 \\
$\mathrm{Ca}: \mathrm{SO}_{4}$ (molar basis) & 0.85 & 0.87 & 0.68 \\
$\mathrm{Na} \mathrm{Cl}$ (molar basis) & 8.3 & 5.7 & 8.1 \\
Evaporation & no & yes & no \\
Dominant $\mathrm{SO}_{4}$ source & Mancos & Mancos & Mancos \\
& Shale & Shale & Shale \\
\hline
\end{tabular}

evapotranspiration processes as indicated by its isotopic signature. Some of this loss returns as irrigation water that slowly enters the Uncompahgre River as groundwater discharge during base flow, accounting for the nearly four-fold increase of flow at Delta compared to that discharged from the Ridgway reservoir upstream (no diversion occurred during base flow).

The influence of the Mancos Shale on the evolution of the isotopic composition of sulfate in the Uncompahgre River can be seen by the smaller decrease in the $\delta^{34} \mathrm{~S}_{\mathrm{SO} 4}$ at the Ridgway station compared to the Ouray station and the marked decrease at the Delta station (fig. 10). The isotope values at the Delta station do not change dramatically from one flow condition to the next indicating that the Mancos Shale influenced all sampling. Calculations, using isotopic data, estimate that between 87 and 90 percent of the sulfate load in the Uncompahgre River at Delta is released from the Mancos Shale. During irrigation-flow conditions, this accounts for 31 percent of the Colorado River sulfate load at Cisco; whereas flow during the same time only accounts for 10 percent of that at Cisco. The evolution of the sulfate data among different flow conditions at the other two upstream stations is likely due to a change of source (see discussions above).

\footnotetext{
${ }^{6}$ The flow of this diversion is considered in the discussion on the Uncompahgre River.
}

\section{Gunnison River Below Gunnison Tunnel, Colorado}

The discharge of the Gunnison River below the Gunnison Tunnel is entirely controlled by Crystal Dam on Morrow Point Reservoir. During irrigation season, water is diverted to the Uncompahgre watershed through the Gunnison Tunnel above this station. ${ }^{6}$ The geology in the watershed above the dam is mostly crystalline rocks (metamorphic and volcanic). The $\mathrm{Ca}: \mathrm{SO}_{4}$ and $\mathrm{Na}: \mathrm{Cl}$ ratios (table 11) are three times greater than expected for dissolution of gypsum and halite, respectively. Contributions of $\mathrm{Ca}$ and $\mathrm{Na}$ from weathering of crystalline rocks upstream explain these elevated ratios. The isotopic composition of dissolved sulfate at this station (fig. 11) changes very little as flow conditions change due to homogenization in the two large reservoirs immediately upstream (Morrow Point and Blue Mesa). These values likely reflect in part mineralization upstream. In the Lake City area drained by a tributary to the Gunnison River, water heavily affected by mineralization averages $\delta^{34} \mathrm{~S}_{\mathrm{SO} 4}=-4 \%$ (Michele Tuttle, unpub. data).

\section{North Fork of the Gunnison River Below Paonia, Colorado}

The flow of water at this station is, in part, controlled by the upstream reservoir on Muddy Creek. Most rocks in this watershed are sedimentary in origin and low-sulfur, Tertiary age coal is actively mined. Cretaceous Mancos Shale crops out in the lowermost portion of the watershed. The moderate $\mathrm{Ca}: \mathrm{SO}_{4}$ and relatively high $\mathrm{Na}: \mathrm{Cl}$ ratios (table 12 ) suggest that dissolution of sodium sulfates such as thenardite $\left(\mathrm{Na}_{2} \mathrm{SO}_{4}\right)$ associated with the Mancos Shale may contribute solutes to the river, decreasing the $\mathrm{Ca}: \mathrm{SO}_{4}$ ratio and increasing the $\mathrm{Na}: \mathrm{Cl}$ ratio. The isotopic composition of the sulfate in the river during base flow $\left(\delta^{34} \mathrm{~S}_{\mathrm{SO} 4}=-11 \%\right.$; fig. 11) is consistent with a portion of the sulfate derived from oxidation of sulfides in marine shale. No sulfate isotope data are available for other times of the year, because recovered sulfate was too low for analyses.

\section{Lower Gunnison River}

\section{Gunnison River at Delta, Colorado}

This station is just above the confluence of the Gunnison River with the Uncompahgre River in Delta. The geology below the Gunnison Tunnel consists of metamorphic rocks about halfway to Delta and then Jurassic and Cretaceous sedimentary rocks, including the Mancos Shale. Selenium concentrations exceed Colorado's freshwater chronic standard of $4.6 \mu \mathrm{g} / \mathrm{L}$ during base flow. During irrigation and base-flow conditions, the $\mathrm{Ca}: \mathrm{SO}_{4}$ and $\mathrm{Na}: \mathrm{Cl}$ ratios (table 13) are similar to those of the Uncompahgre at Delta, indicating that the Mancos Shale contributes significantly to the salt load under these flow conditions (also confirmed by sulfate isotopes). Ratios during 
Table 10. Stream flow, total salt load, and $\mathrm{SO}_{4}$ load for irrigation water diverted from the Gunnison River (Diversion), the Uncompahgre River below reservoir (Reservoir), and for the Uncompahgre River (UR) at Delta. Diversion flows provided by Paul Davidson, Bureau of Reclamation (written commun., 2007 ); reservoir release estimated with data for the USGS Uncompahgre River flow-gaging station at Colona below the reservoir (data available at $h t t p: / / w a t e r d a t a . u s g s . g o v / n w i s / u v ? 09147500$ ). Gain/(loss) was calculated by subtracting the actual flow measured at Delta (UR, Delta) from the sum of Diversion and Reservoir (predicted flow). Gain/loss is then reported as the percentage of predicted flow (diversion plus reservoir).

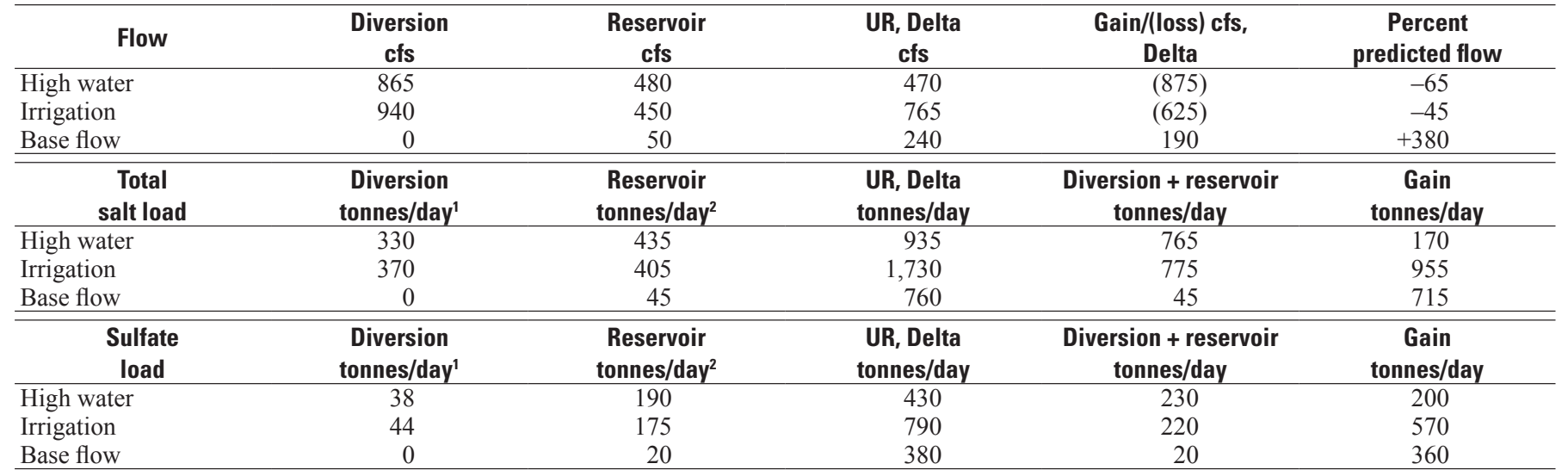

${ }^{1}$ Chemistry for diversion water is discussed in the section below on the Gunnison River below the Gunnison Tunnel.

${ }^{2}$ No chemistry was available for water released from the dam so compositional averages of the water during the three flow conditions (weighted with respect to flow) at the Ridgway station (major contributor to the reservoir) were used for the released water (averages: $160 \mathrm{mg} / \mathrm{L} \mathrm{SO}_{4}$ and $370 \mathrm{mg} / \mathrm{L}$ total dissolved solids). Use of these averages is based on the hypothesis that the reservoir tends to homogenize heterogeneity related to seasonal flow.

high water suggest a mixture of solutes from the North Fork and solutes picked up from the Mancos Shale (the North Fork accounts for 80 percent of the water in the Gunnison River at Delta during this period).

\section{Gunnison River Near Grand Junction, Colorado}

There are no reservoirs on the Gunnison River between Delta and its confluence with the Colorado River. The geology in the area consists predominantly of Cretaceous Mancos Shale and Dakota Sandstone and some Jurassic and Triassic sedimentary rocks. During high-water flow, conductivities increase relative to those at Delta indicating an addition of salts. During base flow, conductivities are lower (table 14) than at the upstream station at Delta 715 compared to $1,080 \mu \mathrm{S} / \mathrm{cm}$ indicating that more dilute water is entering the river from tributaries downstream from Delta. The $\mathrm{Ca}: \mathrm{SO}_{4}$ and $\mathrm{Na}: \mathrm{Cl}$ ratios (table 14) at all times are

Table 11. Summary of geochemical parameters for the Gunnison River below Gunnison Tunnel.

[HW, high-water flow; IRR, irrigation flow; BF, base flow; CR, Colorado River]

\begin{tabular}{lccc}
\hline \multicolumn{1}{c}{$\begin{array}{c}\text { Gunnison River } \\
\text { below tunnel }\end{array}$} & HW & IRR & BF \\
\hline Charge balance (percent) & -7 & -0.4 & 25 \\
Conductivity $(\mu \mathrm{S} / \mathrm{cm})$ & 195 & 205 & 200 \\
Water type & $\mathrm{Ca}-\mathrm{HCO}_{3}$ & $\mathrm{Ca}-\mathrm{HCO}_{3}$ & $\mathrm{Ca}-\mathrm{HCO}_{3}$ \\
Load (tonnes solutes/day) & 275 & 205 & 240 \\
Percent CR load at Cisco & 2 & 3 & 3 \\
$\mathrm{Ca}: \mathrm{SO}_{4}$ (molar basis) & 3.3 & 3.3 & 2.8 \\
$\mathrm{Na} \mathrm{Cl}$ (molar basis) & 3.8 & 3.6 & 3.2 \\
Evaporation & no & no & no \\
Dominant $\mathrm{SO}_{4}$ source & mineralization & mineralization & mineralization \\
\hline
\end{tabular}

similar to those in the Gunnison River at Delta; however, during high water, there is likely a greater contribution of $\mathrm{Na}$ and $\mathrm{SO}_{4}$ from the Mancos than recorded in the ratios at Delta. The $\delta^{34} \mathrm{~S}_{\mathrm{SO} 4}$ values are around $-17 \%$ and point to the Mancos Shale as the dominant source of sulfate (fig. 11).

\section{Geochemical Evolution Along the Gunnison River}

During all three flow regimes, the North Fork of the Gunnison and the Gunnison River below the tunnel are calcium bicarbonate water types; however, the North Fork water trends more toward $\mathrm{Mg}$ and $\mathrm{Na}$ than the tunnel water (fig. 4). At the Delta station and downstream, the Gunnison River becomes a calcium sulfate water type as it picks up sulfate from the Mancos Shale. During high-water flow, the total solute load in the Gunnison River doubles from the North Fork station to the Delta station and nearly doubles again to the Grand Junction station (table AII-1). These increases are much larger than can be explained from the sum of solutes from upstream stations, indicating that additional solutes are acquired through groundwater and other tributary input. The same pattern is observed during irrigation and base flow in the Gunnison River at Delta. At the station near Grand Junction, the solute load is less than the sum of solutes in the Gunnison River at Delta and in the Uncompahgre River at Delta, indicating that some of the load has been removed by diversion or alluvium recharge prior to the inflow of the more dilute water discussed above.

During high-water flow, available metal concentrations (table AI-3) are much higher in the North Fork than in the Gunnison River at the tunnel because the water at the tunnel is being directly released from Crystal Dam and does not 

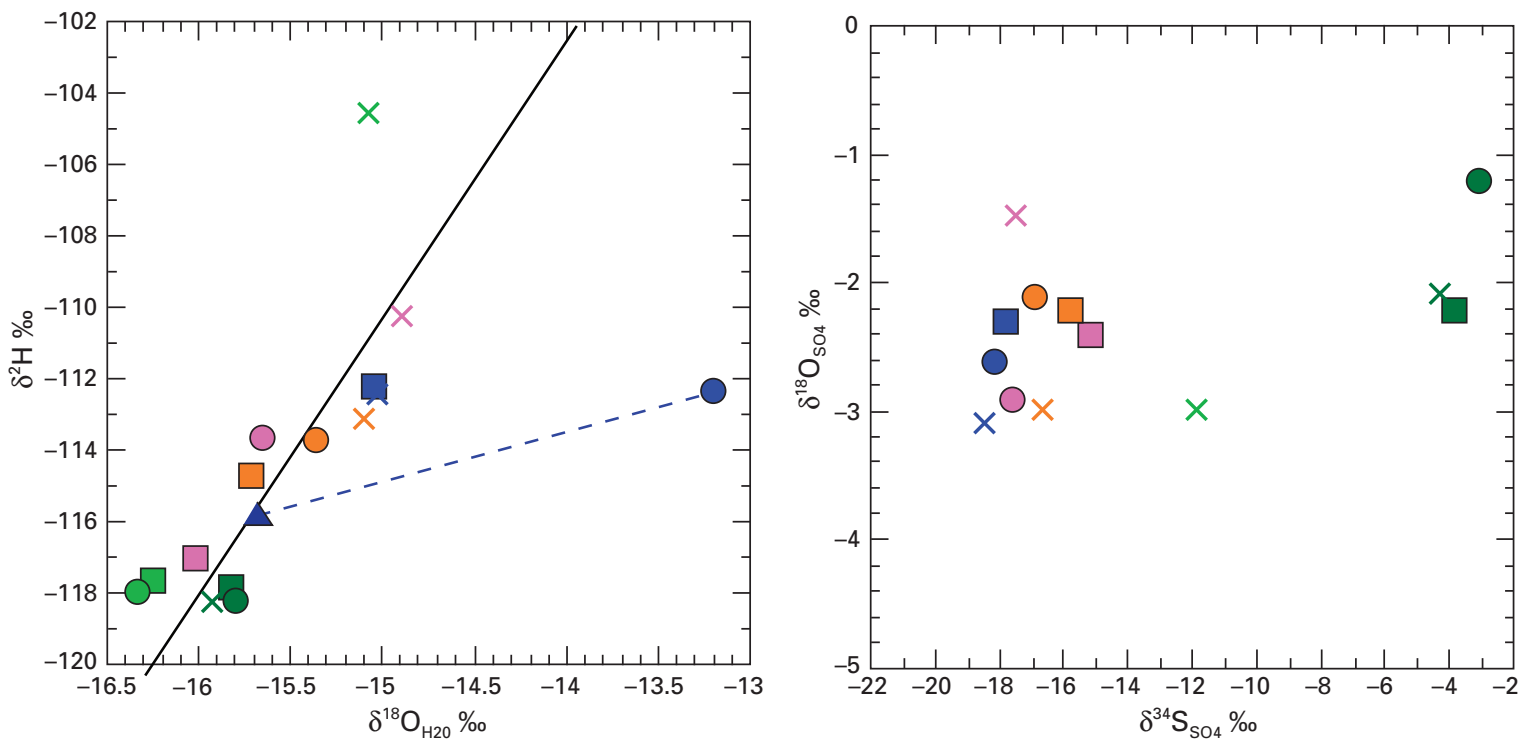

EXPLANATION

\begin{tabular}{|c|c|}
\hline GR-Delta，BF & $\square$ GR-Delta, HW \\
\hline GR-Delta, Irr & X GR-Tunnel, BF \\
\hline GR-Tunnel, HW & GR-Tunnel, Irr \\
\hline GR-Grand Jct., BF & GR-Grand Jct., HW \\
\hline GR-Grand Jct., Irr & $\mathrm{NF}, \mathrm{BF}$ \\
\hline $\mathrm{NF}, \mathrm{HW}$ & $\mathrm{NF}, \mathrm{Irr}$ \\
\hline UR-Delta, BF & UR-Delta, HW \\
\hline UR-Delta, Irr & $\begin{array}{c}\text { Diversion. + reservoir } \\
\text { (calculated) }\end{array}$ \\
\hline
\end{tabular}

Figure 11. Isotope data for the Gunnison River, North Fork, lowermost station on the Uncompahgre River, and calculated $\delta^{2} \mathrm{H}$ and $\delta^{18} 0$ values for irrigation water in the Uncompahgre watershed. HW, high-water flow; Irr, irrigation flow; BF, base flow; GR, Gunnison River; NF, North Fork of the Gunnison River; UR, Uncompahgre River. Hydrogen and oxygen isotopes reported relative to V-SMOW and sulfur isotopes relative to V-CDT.

transport sediment with oxide coatings. The sediment transported in the North Fork consists of detrital components rich in resistate minerals containing $\mathrm{Ba}$, rare earths, $\mathrm{Sc}, \mathrm{Si}$, and $\mathrm{Ti}$ and in oxides and oxide coatings rich in $\mathrm{Al}, \mathrm{Fe}, \mathrm{Mn}$, and adsorbed metals such as $\mathrm{Cd}, \mathrm{Co}, \mathrm{Cr}, \mathrm{Cu}, \mathrm{Ni}, \mathrm{V}$, and $\mathrm{Zn}$. Although $\mathrm{Al}_{\text {(avail) }}$ and $\mathrm{Fe}_{\text {(avail) }}$ concentrations decrease some between Delta and Grand Junction, most trace-metal available concentrations remain similar to concentrations upstream. Except for the Uncompahgre River at Delta during irrigation flow, metal concentrations drop dramatically after high flow, indicating that these metals preferentially are transported in the Gunnison River in the spring runoff adsorbed onto aluminum and iron oxides.

Although most of the water isotopes cluster around the meteoric water line, evaporation is evident in the Uncompahgre River at Delta during irrigation flow (fig. 11). The water isotopes on the North Fork of the Gunnison during base flow is above the GMWL. This relative increase in $\delta^{2} \mathrm{H}$ relative to $\delta^{18} \mathrm{O}_{\mathrm{H} 20}$ often accompanies methanogenesis. Methanogenesis feasibly could occur in this watershed because of the occurrence of coal, however, this explanation is highly speculative.

The sulfate oxygen isotope data occur in a very narrow range ( -3 to $-1 \%$ ) (fig. 11). Conversely, the sulfur isotopes span a fairly broad range $\left(-19\right.$ to $-3 \%$ ). The $\delta^{34} \mathrm{~S}_{\mathrm{SO} 4}$ values in water at the Gunnison Tunnel are a result of the geology upstream including mineralization in the Lake City area $\left(\delta^{34} \mathrm{~S}_{\mathrm{SO} 4}\right.$ of $-4 \%$ ). Sulfate in the Gunnison River downstream from the tunnel is derived mostly from sulfate salts in the Mancos Shale $\left(\delta^{34} \mathrm{~S}_{\mathrm{SO} 4}\right.$ average of $\left.-21 \%\right)$. Sulfate in the North Fork was insufficient for isotopic analyses during high-water and irrigation-flow conditions. The isotopic composition during base flow indicates a mixture of sulfate from the Mancos Shale and another source, possible Tertiary coal upstream of the station (no sulfur isotopic composition of sulfur in such coal was available).

Table 12. Summary of geochemical parameters for the North Fork of the Gunnison River below Paonia.

[HW, high-water flow; IRR, irrigation flow; BF, base flow; CR, Colorado River]

\begin{tabular}{lccc}
\hline $\begin{array}{c}\text { North Fork of the } \\
\text { Gunnison below Paonia }\end{array}$ & HW & IRR & BF \\
\hline Charge balance (percent) & -0.8 & -11 & 9 \\
Conductivity $(\mu \mathrm{S} / \mathrm{cm})$ & 115 & 170 & 310 \\
Water type & $\mathrm{Ca}-\mathrm{HCO}_{3}$ & $\mathrm{Ca}-\mathrm{HCO}_{3}$ & $\mathrm{Ca}-\mathrm{HCO}_{3}$ \\
Load (tonnes solutes/day) & 1,210 & 240 & 145 \\
Percent CR load at Cisco & 7 & 3 & 2 \\
$\mathrm{Ca}: \mathrm{SO}_{4}$ (molar basis) & 4.9 & 2.1 & 2.0 \\
$\mathrm{Na} \mathrm{Cl}$ (molar basis) & 2.9 & 9.3 & 4.5 \\
Evaporation & no & no & no \\
Dominant $\mathrm{SO}_{4}$ source & no data & no data & Mancos Shale \\
& & & $+?$ \\
\hline
\end{tabular}


Table 13. Summary of geochemical parameters for the Gunnison River at Delta.

[HW, high-water flow; IRR, irrigation flow; BF, base flow; CR, Colorado River]

\begin{tabular}{lccc}
\hline \multicolumn{1}{c}{$\begin{array}{c}\text { Gunnison River } \\
\text { at Delta }\end{array}$} & HW & IRR & BF \\
\hline Charge balance (percent) & -3 & -4 & 0.6 \\
Conductivity $(\mu \mathrm{S} / \mathrm{cm})$ & 280 & 900 & 1,080 \\
Water type & $\mathrm{Ca}^{-\mathrm{HCO}_{3}}$ & $\mathrm{Ca}^{-\mathrm{SO}_{4}}$ & ${\mathrm{Ca}-\mathrm{SO}_{4}}$ \\
Load (tonnes solutes/day) & 3,310 & 1,630 & 1,910 \\
Percent CR load at Cisco & 19 & 20 & 20 \\
$\mathrm{Ca}: \mathrm{SO}_{4}$ (molar basis) & 1.3 & 0.84 & 0.72 \\
$\mathrm{Na} \mathrm{Cl}$ (molar basis) & 4.4 & 7.2 & 7.2 \\
Evaporation & no & no & no \\
Dominant $\mathrm{SO}_{4}$ source & Mancos & Mancos & Mancos \\
& Shale & Shale & Shale \\
\hline
\end{tabular}

Table 14. Summary of geochemical parameters for the Gunnison River near Grand Junction.

[HW, high-water flow; IRR, irrigation flow; BF, base flow; CR, Colorado River]

\begin{tabular}{lccc}
\hline $\begin{array}{c}\text { Gunnison River near } \\
\text { Grand Junction }\end{array}$ & HW & IRR & BF \\
\hline Charge balance (percent) & 4 & 4 & 4 \\
Conductivity $(\mu \mathrm{S} / \mathrm{cm})$ & 455 & 855 & 715 \\
Water type & $\mathrm{Ca}^{-\mathrm{SO}_{4}}$ & $\mathrm{Ca}_{4} \mathrm{SO}_{4}$ & mixed \\
Load (tonnes solutes/day) & 5,150 & 2,540 & 2,090 \\
Percent CR load at Cisco & 30 & 31 & 22 \\
$\mathrm{Ca}: \mathrm{SO}_{4}$ (molar basis) & 1.1 & 0.88 & 0.81 \\
$\mathrm{Na}: \mathrm{Cl}$ (molar basis) & 7.4 & 6.5 & 5.2 \\
Evaporation & no & no & no \\
Dominant $\mathrm{SO}_{4}$ source & Mancos & Mancos & Mancos \\
& Shale & Shale & Shale \\
\hline
\end{tabular}

\section{Dolores and San Miguel Rivers}

Maps of the watersheds of the Dolores River are in figure 12. The San Miguel River is the only major tributary to the Dolores River. The flow of the Dolores River is largely controlled by the McPhee Reservoir upstream from the Dolores-San Miguel confluence.

\section{San Miguel River at Uravan, Colorado}

The flow of water at this station (fig. 12) is partially affected by small reservoirs upstream (for example, Taylor Lake, a damned natural lake near the headwaters). The watershed (fig. 12) is underlain by volcanic rocks near the headwaters and Pennsylvanian to Jurassic and Cretaceous rocks in the lower portion. Mancos Shale crops out in some tributaries along the entire stretch of the river. The Ca: $\mathrm{SO}_{4}$ and $\mathrm{Na}: \mathrm{Cl}$ ratios (table 15) look similar to those in the Uncompahgre near the Ridgway station. Tributaries to the Uncompahgre from the west drain similar rocks as the San Miguel in the upper portion of its watershed. The $\mathrm{Ca}: \mathrm{SO}_{4}$ ratios drop to one or below after high-water flow suggesting that gypsum dissolution alone controls these solutes. Under all three flow conditions, the sulfate isotopes (fig. 13) are slightly lighter than those for sulfate in the Dolores River headwaters, suggesting that there may be a small component of sulfate derived from the Mancos Shale. However, most of the sulfate is derived from weathering of mineralized rocks in the upper portion of the watershed, similar to those that supply sulfate in the headwaters of the Uncompahgre and Dolores Rivers.

\section{Dolores River at Dolores, Colorado}

The flow of water at this station is not regulated by any significant reservoirs upstream. The geology in the watershed upstream is varied with predominantly Pennsylvanian and Permian sedimentary rocks. During high-water flow, the water is a calcium bicarbonate type (fig. 4) with a high $\mathrm{Ca}: \mathrm{SO}_{4}$ ratio (table 16) that decreases during irrigation and base flow. Similar $\delta^{34} \mathrm{~S}_{\mathrm{SO} 4}$ values during all flow conditions suggest a common source of sulfate (fig. 13). These isotope values are similar to those in the Animas watershed (average $\delta^{34} \mathrm{~S}_{\text {pyrite }}$ of $-3 \%$; Nordstrom and others, 2007), a parallel drainage to the east that is extensively mineralized.

\section{Dolores River at Bedrock, Colorado}

The flow of this stretch of the river is controlled by McPhee Reservoir. The dominant geologic unit at the Bedrock station is the Paradox Formation of the Hermosa Group, which contains beds of anhydrite, halite, and some potash. Similar rocks are exposed in the Gypsum Valley upstream. The Mancos Shale is aerially extensive in the Disappointment Creek catchment, which drains into the Dolores River upstream from Bedrock in the spring and intermittently during monsoon season in the late summer (G. Breit, oral commun., 2007). The Dolores River water at Bedrock transitions from a $\mathrm{Ca}-\mathrm{HCO}_{3}$ type during high water to a $\mathrm{Na}-\mathrm{Cl}$ water during irrigation and base-flow conditions (fig. 4). This transition is likely due to a large release of water from the McPhee Reservoir during high spring runoff $(2,000$ to more than 4,000 cfs; May through June, 2004) compared to very low release during the rest of the year ( $<100 \mathrm{cfs})$ (http://www.usbr.gov/uc/wcao/water/rsvrs/ds/mcphee.html). No chemistry is available between McPhee Reservoir and Bedrock, so an average of chemistry for all three flow conditions, weighted with respect to flow at the Dolores station, was used as the composition of reservoir outflow. The $\mathrm{Ca}: \mathrm{SO}_{4}$ ratio (table 17) is greater than one indicating that $\mathrm{Ca}$ has an additional source other than dissolution of gypsum in the Mancos Shale or anhydrite in the Paradox Formation. The $\mathrm{Na}: \mathrm{Cl}$ ratio during high water is greater than one, indicating that halite dissolution is not the sole Na source; dissolution of sodium sulfates in the Mancos Formation in Disappointment Valley may contribute to the increase. During irrigation and base flow, as the water type changes to a $\mathrm{Na}-\mathrm{Cl}$ water (fig. 4), the $\mathrm{Na}: \mathrm{Cl}$ ratio is essentially one (table 17), indicating that the primary source of solutes under these flow conditions is dissolution of halite in the Paradox Formation. The sulfur isotopic composition varies systematically among high-water, irrigation, and base-flow conditions (fig. 13). During high-water flow, $\delta^{34} \mathrm{~S}_{\mathrm{SO} 4}$ is isotopically light (-13\%). Mixing of the sulfate in the Dolores River at Dolores $\left(\delta^{34} \mathrm{~S}_{\mathrm{SO} 4}=-3.4 \%\right.$ ) with the increased load acquired along the flow to Bedrock, supports 
Lower Dolores River Watershed (11)

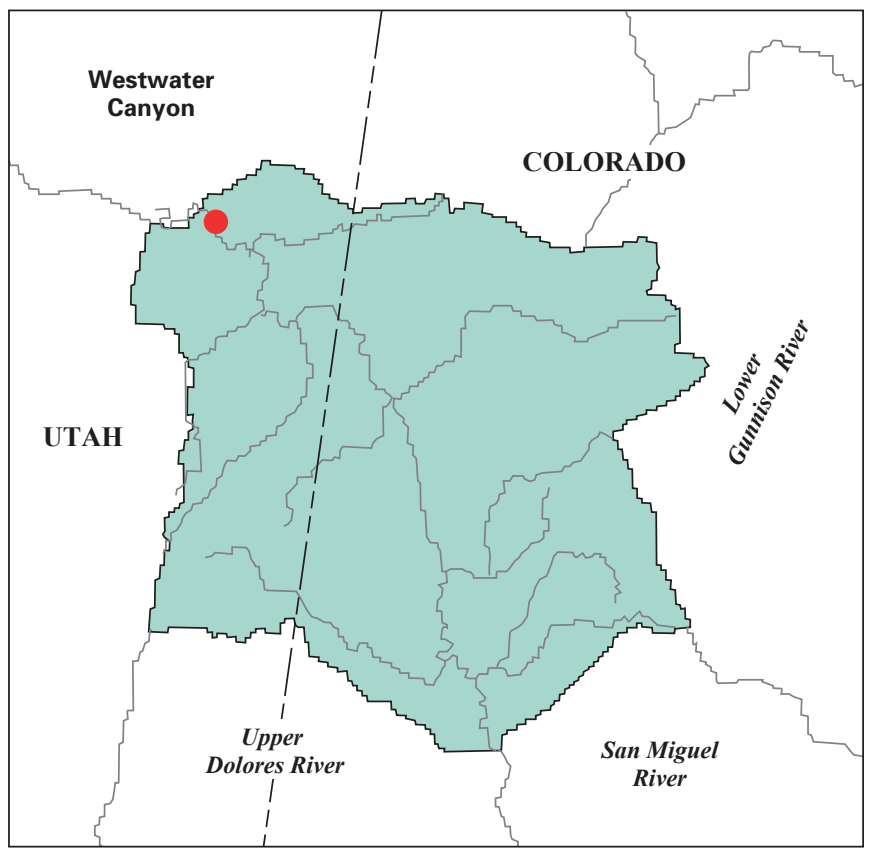

San Miguel River Watershed (10)

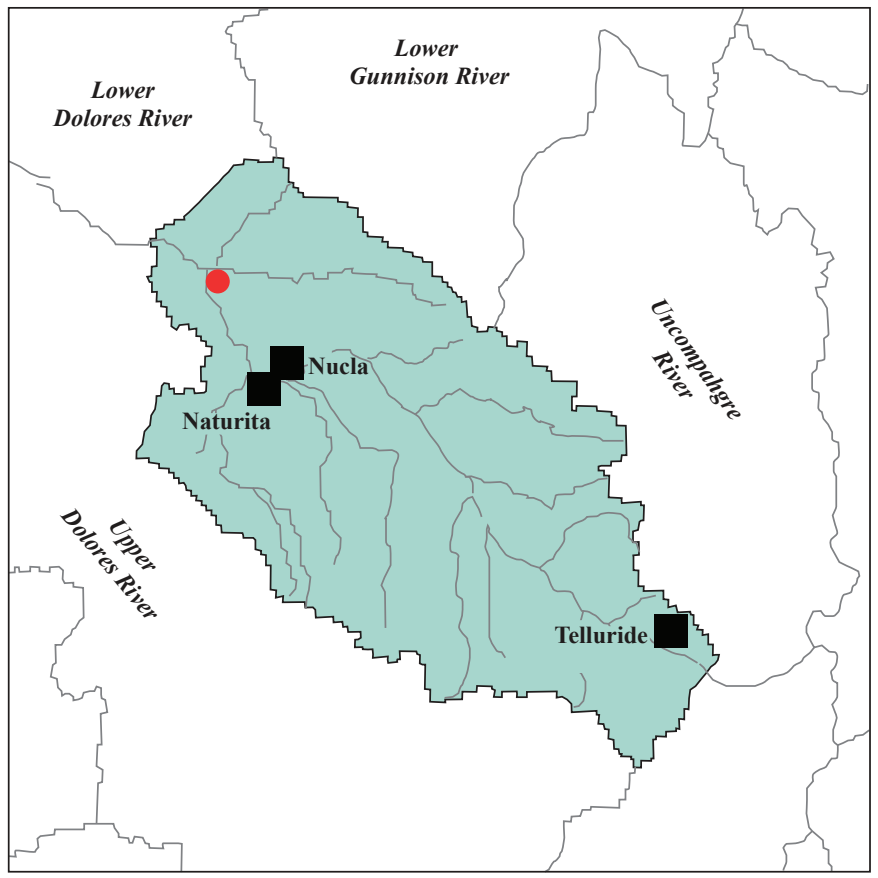

the hypothesis that the sulfate during high-water flow in the Dolores River at Bedrock is a mixture of that from upstream (45 percent) and from the Mancos Shale (55 percent). During irrigation, the $\delta^{34} \mathrm{~S}_{\mathrm{SO} 4}$ value increases significantly to $2.3 \%$, suggesting that dissolution of anhydrite in the Paradox Formation $\left(\delta^{34} \mathrm{~S}_{\mathrm{SO} 4}\right.$ of $13 \%$; Claypool and others, 1980; Tuttle and others, 1996) contributes to the sulfate mix. This result is consistent with dissolution of halite in related evaporite beds during this time of year. The base flow $\delta^{34} \mathrm{~S}_{\mathrm{SO} 4}$ value decreases to $-1.2 \%$, indicating that anhydrite contributes a smaller proportion of sulfate during this time of the year.

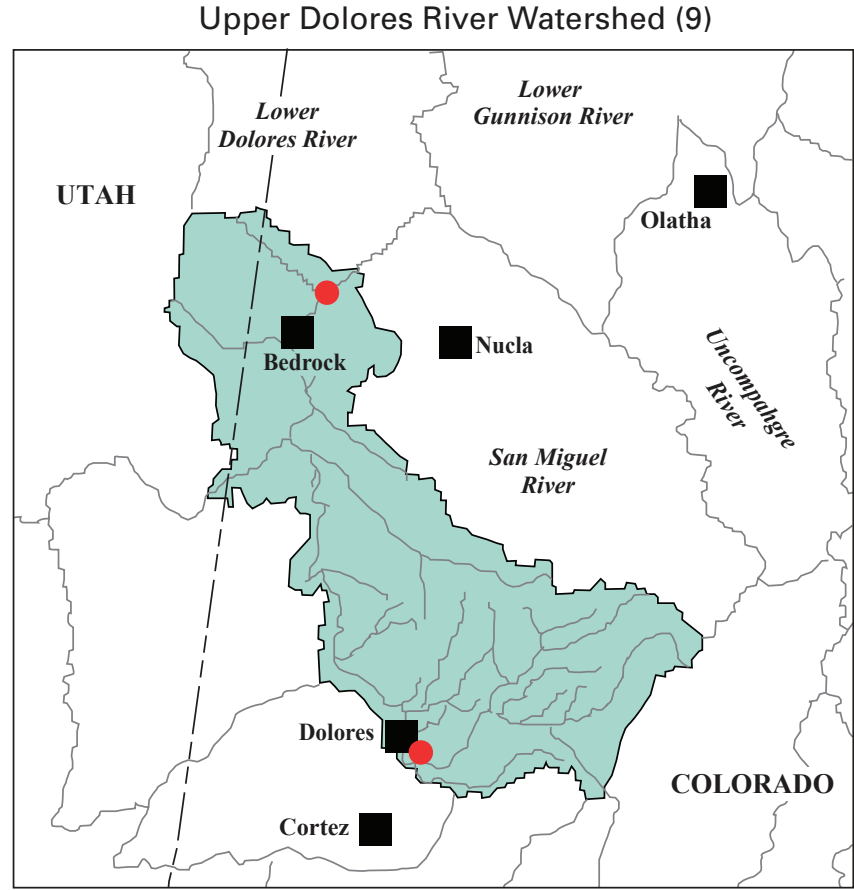

Figure 12. Map of the upper and lower Dolores River watersheds and the San Miguel River watershed showing adjacent sampled watersheds. Red dots, stations sampled. Black dashed line is the border between Utah and Colorado. Maps modified from http://www.epa.gov/surf/.

\section{Dolores River Near Cisco, Utah}

The confluence of the Dolores River with the Colorado River is just upstream from our most downstream Colorado River station near Cisco. There are no dams on the Dolores River downstream from Bedrock to this station; however, intercept of shallow saline ground water in the Paradox Valley and injection into deep wells occurs to help decrease the flow of salt to the Colorado River. This interception/injection is part of the Colorado River Basin Salinity Control Program Paradox Valley Unit operated by the Bureau of Reclamation. The unit was designed to remove 128,000 tons of salt annually (62 percent of the salt released to the Dolores River from the Paradox Formation as it crosses the Paradox Valley; http://www.usbr.gov/dataweb/html/paradox.html). Chafin (2003) reports that 90 percent of the salt between 1988 and 2001 was removed.

The water at the Cisco station is a calcium bicarbonate type during high-water flow, a mixed type during irrigation flow, and a sodium chloride type during base flow (fig. 4). During highwater flow, the $\mathrm{Ca}: \mathrm{SO}_{4}$ and $\mathrm{Na}: \mathrm{Cl}$ ratios (table 18) look similar to those in the river at Bedrock. During irrigation and base-flow conditions, both $\mathrm{Ca}: \mathrm{SO}_{4}$ and $\mathrm{Na}: \mathrm{Cl}$ ratios approach one, suggesting that the primary sources of solutes are gypsum/anhydrite dissolution and halite dissolution. The halite is derived from the Paradox Formation. The isotopes of sulfate (fig. 13) indicate that the source of the sulfate is a mixture from the Mancos Shale (dominant source), anhydrite from the Paradox Formation, and mineralization upstream. 
Table 15. Summary of geochemical parameters for the San Miguel River at Uravan.

[HW, high-water flow; IRR, irrigation flow; BF, base flow; CR, Colorado River]

\begin{tabular}{lccc}
\hline \multicolumn{1}{c}{$\begin{array}{c}\text { San Miguel River } \\
\text { at Uravan }\end{array}$} & HW & IRR & BF \\
\hline Charge balance (percent) & -0.9 & -1 & 0.8 \\
Conductivity ( $\mu \mathrm{S} / \mathrm{cm})$ & 350 & 565 & 750 \\
Water type & $\mathrm{Ca}-\mathrm{HCO}_{3}$ & $\mathrm{Ca}^{-\mathrm{SO}_{4}}$ & $\mathrm{Ca}_{4} \mathrm{SO}_{4}$ \\
Load (tonnes solutes/day) & 800 & 220 & 205 \\
Percent CR load at Cisco & 5 & 3 & 2 \\
$\mathrm{Ca}: \mathrm{SO}_{4}$ (molar basis) & 1.5 & 1.0 & 0.92 \\
$\mathrm{Na} \mathrm{Cl}$ (molar basis) & 2.8 & 3.1 & 3.0 \\
Evaporation & no & no & no \\
Dominant $\mathrm{SO}_{4}$ source & mineralization & mineralization & mineralization \\
\hline
\end{tabular}

\section{Geochemical Evolution Along the Dolores River}

Below the Dolores station, the water type of the Dolores River changes during the year from a calcium bicarbonate type during high water to a mixed or sodium chloride type during irrigation and base flow (fig. 4). This change reflects the input of solutes from salts derived from the Mancos Shale and Paradox Formation. During high water, transported sediment consists of components rich in resistate minerals containing $\mathrm{Ba}$, rare earths, $\mathrm{Si}$, and $\mathrm{Ti}$, and in oxides and oxide

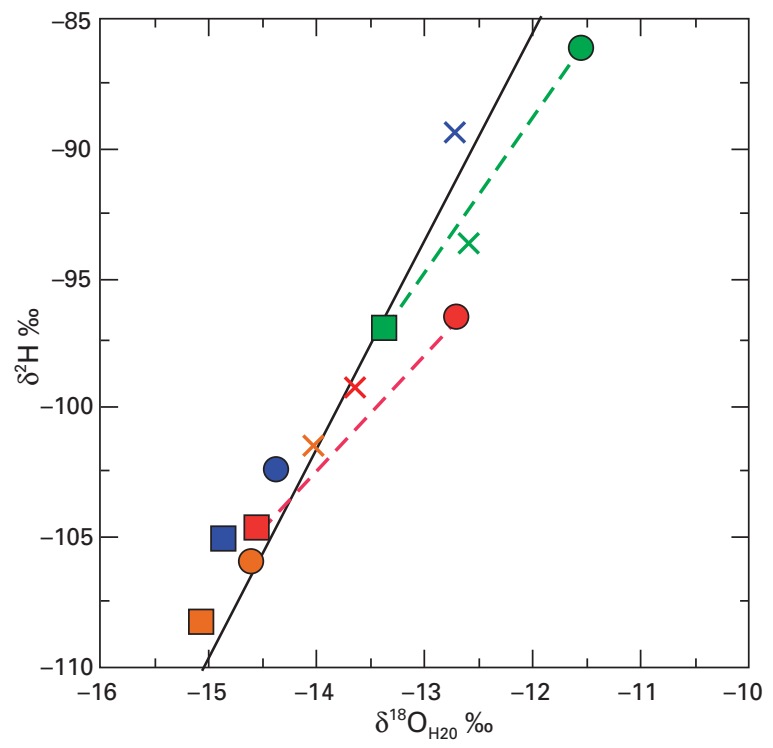

coatings rich in $\mathrm{Al}, \mathrm{Fe}$, and $\mathrm{Mn}$, and adsorbed metals such as $\mathrm{Cd}, \mathrm{Co}, \mathrm{Cr}, \mathrm{Cu}, \mathrm{Ni}, \mathrm{V}$, and $\mathrm{Zn}$ (table AI-3). During the irrigation season, the Dolores River below McPhee Reservoir is also high in many of these available metals even though the flow has decreased dramatically. This is especially evident at the Bedrock station. The cause for the transport of sediment in the Dolores during such low-flow conditions is not readily apparent.

Figure 13 shows that most of the water in the Dolores River falls on the GMWL with respect to its isotopic composition. The small deviation of water at Bedrock and Cisco during irrigation flow suggests that the water has undergone some evaporation.

The isotopes of sulfate in the San Miguel River at Uravan and the Dolores River at Dolores are similar and largely controlled by mineralization in the upper portion of these watersheds (fig. 13); however, in the San Miguel watershed, dissolution of salts in the Mancos Shale soil contribute a small proportion of the sulfate. The influence of the Mancos Shale in the vicinity of Disappointment Valley during high-water flow and the Paradox Formation evaporites in the Paradox Valley during irrigation flow is evident in the Dolores River at Bedrock. The composition of sulfate in the Dolores River near Cisco is a mixture of the sulfate in the river at Bedrock and the sulfate in the San Miguel River.

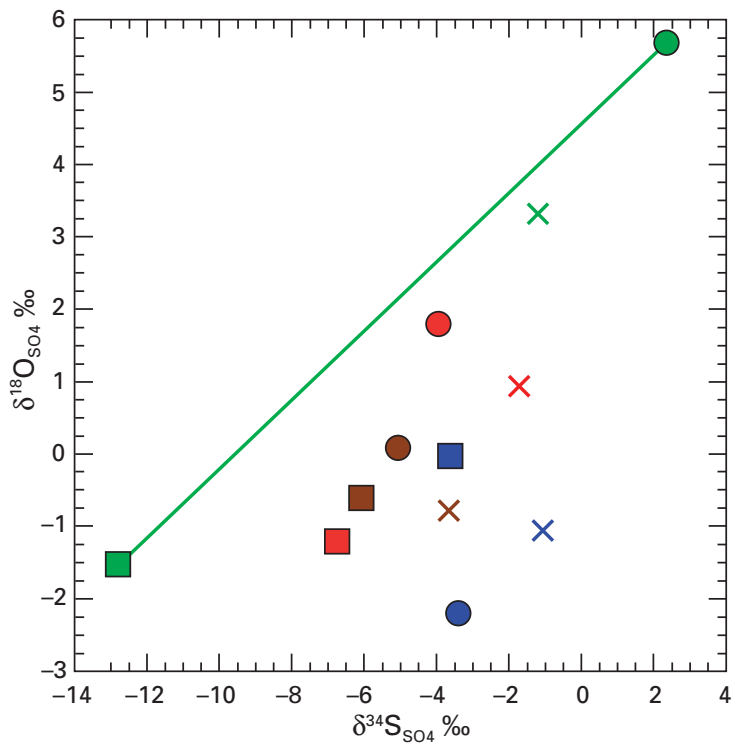

EXPLANATION

$\begin{array}{llll}\times & \text { DR-Delores, BF } & \square & \text { DR-Delores, HW } \\ \bigcirc & \text { DR-Delores, Irr } & \times & \text { DR-Bedrock, BF } \\ \square & \text { DR-Bedrock, HW } & \bigcirc & \text { DR-Bedrock, Irr } \\ \times & \text { DR-Cisco, BF } & \square & \text { DR-Cisco, HW } \\ \bigcirc & \text { DR-Cisco, Irr } & \times & \text { SM-Uravan, BF } \\ \square & \text { SM-Uravan, HW } & \bigcirc & \text { SM-Uravan, Irr }\end{array}$

Figure 13. Isotope data for the Dolores and San Miguel Rivers. HW, high-water flow; Irr, irrigation flow; BF, base flow; SM, San Miguel River; DR, Dolores River. Hydrogen and oxygen isotopes reported relative to V-SMOW and sulfur isotopes relative to $\mathrm{V}$-CDT. 
Table 16. Summary of geochemical parameters for the Dolores River at Dolores.

[HW, high-water flow; IRR, irrigation flow; BF, base flow; CR, Colorado River]

\begin{tabular}{lccc}
\hline \multicolumn{1}{c}{$\begin{array}{c}\text { Dolores River } \\
\text { at Dolores }\end{array}$} & HW & IRR & BF \\
\hline Charge balance (percent) & 4 & -1 & -6 \\
Conductivity $(\mu \mathrm{S} / \mathrm{cm})$ & 155 & 265 & 330 \\
Water type & $\mathrm{Ca}-\mathrm{HCO}_{3}$ & $\mathrm{Ca}-\mathrm{HCO}_{3}$ & $\mathrm{Ca}-\mathrm{HCO}_{3}$ \\
Load (tonnes solutes/day) & 1,160 & 115 & 71 \\
Percent CR load at Cisco & 7 & 1 & $<1$ \\
$\mathrm{Ca}: \mathrm{SO}_{4}$ (molar basis) & 6.3 & 3.2 & 3.0 \\
$\mathrm{Na} \mathrm{Cl}$ (molar basis) & 1.2 & 1.3 & 1.3 \\
Evaporation & no & no & no \\
Dominant $\mathrm{SO}_{4}$ source & mineralization mineralization mineralization \\
\hline
\end{tabular}

Table 17. Summary of geochemical parameters for the Dolores River at Bedrock.

[HW, high-water flow; IRR, irrigation flow; BF, base flow; CR, Colorado River]

\begin{tabular}{lccc}
\hline \multicolumn{1}{c}{$\begin{array}{c}\text { Dolores River } \\
\text { at Bedrock }\end{array}$} & HW & IRR & BF \\
\hline Charge balance (percent) & 0.9 & 2 & -4 \\
Conductivity $(\mu \mathrm{S} / \mathrm{cm})$ & 400 & 1,510 & 1,010 \\
Water type & $\mathrm{Ca}-\mathrm{HCO}_{3}$ & $\mathrm{Na}-\mathrm{Cl}$ & $\mathrm{Na}-\mathrm{Cl}$ \\
Load (tonnes solutes/day) & 930 & 175 & 69 \\
Percent CR load at Cisco & 5 & 2 & $<1$ \\
$\mathrm{Ca} \mathrm{SO}_{4}$ (molar basis) & 2.1 & 1.8 & 2.5 \\
$\mathrm{Na} \mathrm{Cl}$ (molar basis) & 1.6 & .95 & 1.0 \\
Evaporation & no & yes & yes \\
Dominant $\mathrm{SO}_{4}$ source & Mancos & Paradox & Paradox Formation \\
& Shale & Formation & + Mancos Shale \\
\hline
\end{tabular}

\section{Geochemistry in Main Stem Colorado River Above Cisco, Utah}

Maps of the main stem Colorado River watersheds sampled in this study are shown in figure 14. Also included in this discussion section is Plateau Creek, a tributary to the Colorado River within the Colorado River headwater-plateau watershed.

\section{Colorado River Near Kremmling, Colorado}

The Colorado River near Kremmling station is located in the upper portions of the Colorado River headwater watershed (fig. 14). The composition of the water sampled at this station is considered the Colorado River headwaters natural baseline for this study as the station is the farthest upstream site sampled and is the least impacted by anthropogenic activities, although there are five major reservoirs located upstream. The similarity in conductivities during irrigation and base flow indicates minimal influence from irrigation in this watershed.

The dominant geology in this and tributary watersheds is igneous and metamorphic rocks; however, there are some exposures of Permian, Jurassic, Cretaceous, and Tertiary sedimentary rocks. This station has calcium bicarbonate water (fig. 4) with $\mathrm{Ca}: \mathrm{SO}_{4}$ and $\mathrm{Na}: \mathrm{Cl}$ ratios varying little throughout the year (table 19). Ratios of $\mathrm{Ca}: \mathrm{SO}_{4}$ and $\mathrm{Na}: \mathrm{Cl}$ are two or greater and consistent with crystalline rock sources that release bicarbonate as well as these cations. The $\delta^{34} \mathrm{~S}_{\mathrm{SO} 4}$ values of dissolved sulfate (see fig. 16 in Geochemical Evolution of the Colorado River Above Cisco) at this station vary little with changing flow conditions and are intermediate at about $-5 \%$; however, the $\delta^{18} \mathrm{O}_{\mathrm{SO} 4}$ is larger during high flow. The $\delta^{34} \mathrm{~S}_{\mathrm{SO} 4}$ and $\delta^{18} \mathrm{O}_{\mathrm{SO} 4}$ values during base flow (see fig. 16 in Geochemical Evolution of the Colorado River Above Cisco) are assumed to be the starting composition of sulfate in the Colorado River.

\section{Colorado River Above Glenwood Springs, Colorado}

The Colorado River above Glenwood Springs station is downstream from the confluence of the Colorado River with the Eagle River (fig. 14). There are no dams on the Colorado River between Kremmling and this station. Hot springs occur and discharge water along a portion of the Colorado River upstream from this station. As was the case at the Kremmling station, there is no influence due to irrigation as observed in the similar conductivities during irrigation and base flow.

The geology along the stretch of the Colorado from Kremmling halfway to this station consists mostly of igneous and metamorphic rocks. From that point downstream to the sampling station, sedimentary rocks of Cambrian through Permian age dominate; they include the Eagle Valley Evaporite and mudstones/sandstones of the Maroon Formation. Some Cretaceous Mancos Shale and Dakota Sandstone also crop out. The water is a calcium bicarbonate type during high-water flow and a mixed type during other flow conditions, moving more toward a sodium chloride type water during base flow (fig. 4). This change reflects the high content of $\mathrm{Na}$ and $\mathrm{Cl}$ in the hot spring water, which is overwhelmingly a sodium chloride water

Table 18. Summary of geochemical parameters for the Dolores River near Cisco.

[HW, high-water flow; IRR, irrigation flow; BF, base flow; CR, Colorado River]

\begin{tabular}{|c|c|c|c|}
\hline $\begin{array}{c}\text { Dolores River, } \\
\text { Cisco }\end{array}$ & HW & IRR & BF \\
\hline Charge balance (percent) & -0.2 & 7 & -4 \\
\hline Conductivity $(\mu \mathrm{S} / \mathrm{cm})$ & 375 & 1,070 & 1,750 \\
\hline Water type & $\mathrm{Ca}-\mathrm{HCO}_{3}$ & mixed & $\mathrm{Na}-\mathrm{Cl}$ \\
\hline Load (tonnes solutes/day) & $1,280^{3}$ & 445 & 535 \\
\hline Percent CR load at Cisco & 8 & 5 & 6 \\
\hline $\mathrm{Ca}: \mathrm{SO}_{4}$ (molar basis) & 1.8 & 0.96 & 1.3 \\
\hline $\mathrm{Na}: \mathrm{Cl}$ (molar basis) & 1.7 & 0.89 & 1.1 \\
\hline Evaporation & no & yes & no \\
\hline Dominant $\mathrm{SO}_{4}$ source & $\begin{array}{l}\text { Mancos } \\
\text { Shale }\end{array}$ & $\begin{array}{l}\text { Paradox } \\
\text { Formation }\end{array}$ & $\begin{array}{c}\text { Paradox Formation } \\
+ \text { Mancos Shale }\end{array}$ \\
\hline
\end{tabular}




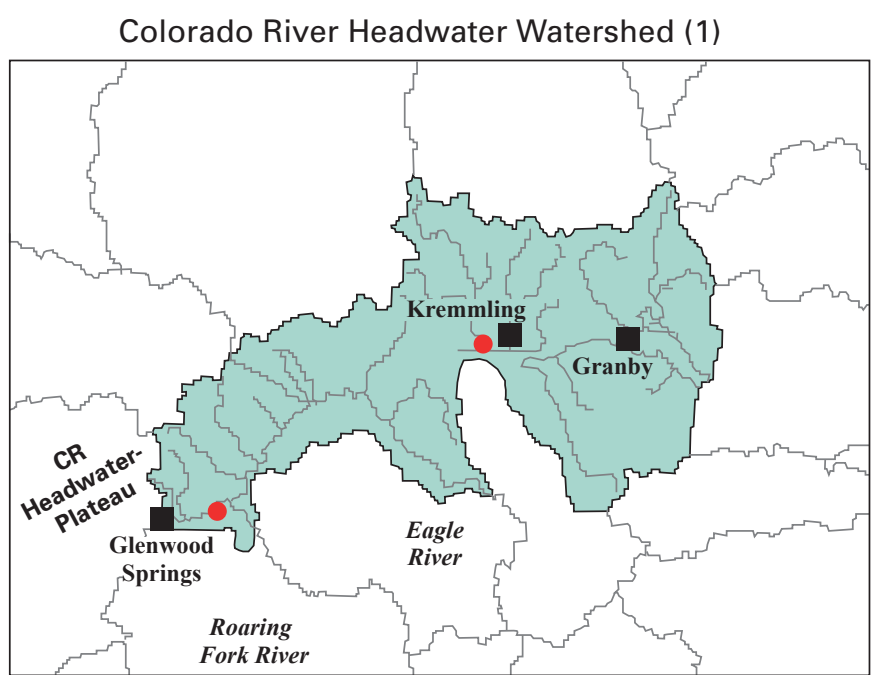

Colorado River Headwater-Plateau (8)
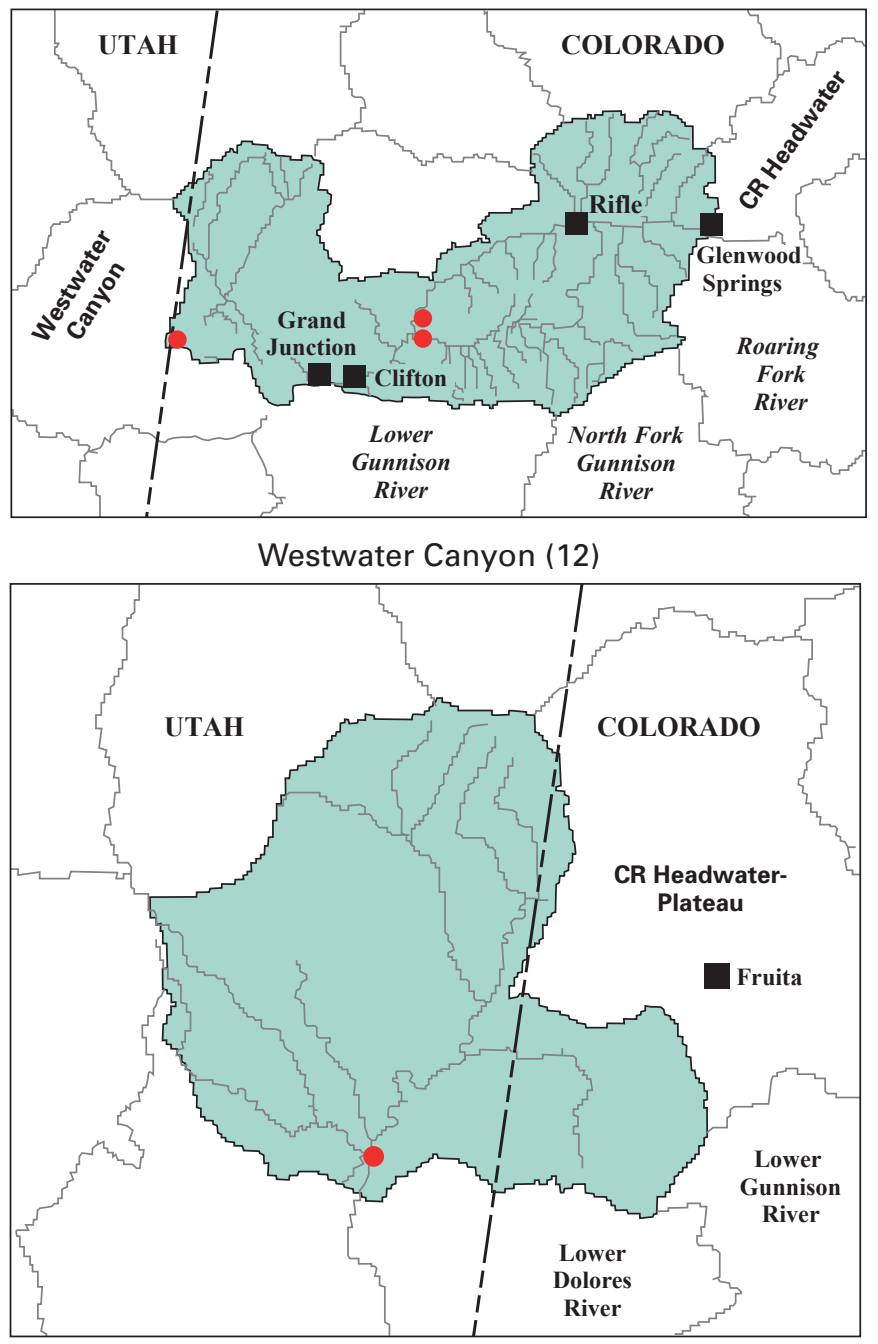

Figure 14. Maps of Colorado River (CR) headwater (no. 1 on fig. 5), Colorado River headwater-plateau and Westwater Canyon watersheds (nos. 8 and 12, respectively on fig. 5) showing adjacent sampled watersheds. Black dashed line is the border between Utah and Colorado. Red dots, stations sampled. Maps modified from http://www.epa.gov/surf/. type (Glenwood Springs (GW) hot spring data in table AI-3 and in Eisenhauer, 1983). The trends in the $\mathrm{Ca}: \mathrm{SO}_{4}$ and $\mathrm{Na}: \mathrm{Cl}$ ratios (table 20) throughout the year mimic those in the Eagle River at Gypsum, suggesting that the source of the additional salts to the Colorado River (fig. 3) are similar to those to the downstream portion of the Eagle River. Sulfur isotopic compositions (see fig. 16 in Geochemical Evolution of the Colorado River Above Cisco) suggest a mixture of two sources of sulfate during irrigation and base flow - that inherited from the Kremmling station and a major contribution from the Eagle Valley Evaporite.

\section{Colorado River Near Cameo, Colorado}

The Colorado River below the station above Glenwood Springs is not controlled by any large reservoirs; however, in Glenwood Canyon, the water is diverted and returned to the river to generate hydroelectric power. The Roaring Fork River and numerous hot springs enter the Colorado River upstream from this station. The geology along this stretch of the river changes from Mississippian limestone and metamorphic rocks in Glenwood Canyon to Tertiary rocks of the Wasatch and Green River Formations, which are variegated nonmarine mudstone and lacustrine oil shale, respectively, to the Cretaceous coal-bearing Mesaverde Formation in De Beque Canyon just above Cameo. The water at this station is a calcium bicarbonate type during high-water flow and a mixed type during the rest of the year as it picks up greater proportions of sodium and chloride from Eagle Valley Evaporite (fig. 4). The $\mathrm{Ca}: \mathrm{SO}_{4}$ and $\mathrm{Na}: \mathrm{Cl}$ ratios (table 21) are very similar to those in the Colorado River at the station above Glenwood Springs.

Sulfur isotopes (see fig. 16 in Geochemical Evolution of the Colorado River Above Cisco) are similar to those in the Roaring Fork during high-water flow and to those at the station above Glenwood Springs during irrigation and base-flow conditions. The isotopic data combined with the sulfate load data have been used to estimate the sulfate isotopic composition of all sulfate unaccounted for in table 22. Sulfate from this unknown source(s) has an isotopic signature of 7.1, 3.4, and $6.5 \%$ during high-water, irrigation, and base-flow conditions, respectively (table 22). Possibilities that may contribute in varying proportions to this unknown sulfate load are sulfate in mudstones of the Wasatch Formation ( -13 to $-40 \%$; Tuttle, unpub. data) and oxidized sulfides in the Green River Formation (average 15 to $35 \%$; Tuttle and Goldhaber, 1993), both of which crop out along the river and in tributary watersheds through this stretch; sulfur in the Mesaverde Formation that crops out in De Beque Canyon and associated tributaries (1.5 to $3.5 \%$; table AIII-3); sulfate in ground water associated with the abandoned Rifle Uranium Mill sites (-6.5 to $2.4 \%$; table AI-3); and, possibly, produced water related to gas drilling (unknown isotopic composition). Additional detailed sampling along this stretch would be needed to quantify relative contributions from these possible sources. 
Table 19. Summary of geochemical parameters for the Colorado River near Kremmling.

[HW, high-water flow; IRR, irrigation flow; BF, base flow; CR, Colorado River]

\begin{tabular}{lccc}
\hline \multicolumn{1}{c}{$\begin{array}{c}\text { Colorado River, } \\
\text { Kremmling }\end{array}$} & HW & IRR & BF \\
\hline Charge balance (percent) & 24 & -2 & 3 \\
Conductivity $(\mu \mathrm{S} / \mathrm{cm})$ & 140 & 210 & 200 \\
Water type & $\mathrm{Ca}-\mathrm{HCO}_{3}$ & $\mathrm{Ca}^{-\mathrm{HCO}_{3}}$ & $\mathrm{Ca}-\mathrm{HCO}_{3}$ \\
Load (tonnes solutes/day) & 310 & 365 & 280 \\
Percent CR load at Cisco & 2 & 4 & 3 \\
$\mathrm{Ca}: \mathrm{SO}_{4}$ (molar basis) & 2.2 & 2.6 & 2.2 \\
$\mathrm{Na}: \mathrm{Cl}$ (molar basis) & 2.6 & 2.0 & 2.4 \\
Evaporation & no & no & no \\
Dominant $\mathrm{SO}_{4}$ source & various & various & various \\
& sources & sources & sources \\
\hline
\end{tabular}

Table 20. Summary of geochemical parameters for the Colorado River above Glenwood Springs.

[HW, high-water flow; IRR, irrigation flow; BF, base flow; CR, Colorado River]

\begin{tabular}{lccc}
\hline \multicolumn{1}{c}{$\begin{array}{c}\text { Colorado River, } \\
\text { Glenwood Springs }\end{array}$} & HW & IRR & BF \\
\hline Charge balance (percent) & 7 & -4 & 7 \\
Conductivity $(\mu \mathrm{S} / \mathrm{cm})$ & 250 & 515 & 565 \\
Water type & $\mathrm{Ca}-\mathrm{HCO}_{3}$ & mixed & mixed \\
Load (tonnes solutes/day) & 3,180 & 1,570 & 1,460 \\
Percent CR load at Cisco & 19 & 19 & 15 \\
$\mathrm{Ca}: \mathrm{SO}_{4}$ (molar basis) & 3.0 & 2.0 & 1.7 \\
$\mathrm{Na} \mathrm{Cl}$ (molar basis) & 1.4 & 1.2 & 1.2 \\
Evaporation & no & no & no \\
Predominant $\mathrm{SO}_{4}$ source & evaporites & evaporites & evaporites \\
\hline
\end{tabular}

\section{Plateau Creek Near Cameo, Colorado}

The flow of Plateau Creek is controlled, in part, by several small reservoirs. The geology upstream is predominantly mudstones of the Tertiary Wasatch Formation and basalt. The water is calcium bicarbonate type during high-water flow and a mixed type during other times of the year (fig. 4) with a greater proportion of magnesium, but the dominant anion remains $\mathrm{HCO}_{3}$, consistent with weathering of basaltic material. The $\mathrm{Ca}: \mathrm{SO}_{4}$ and $\mathrm{Na}: \mathrm{Cl}$ ratios (table 23) are high, also consistent with weathering of basalt. Isotopes of sulfate (see fig. 16 in Geochemical Evolution of the Colorado River Above Cisco) do not vary and are similar to those in the Colorado River near Kremmling during high water and in the Dolores River at Dolores during irrigation and base flow; the dominant geology upstream from these two stations is also crystalline rocks, the likely source of this signature.

\section{Colorado River Near Colorado-Utah State Line}

The flow of the river downstream from Cameo is not dramatically affected by reservoirs; however, during irrigationflow conditions, water diversion and return occurs. The Gunnison River is a major tributary entering along this stretch. The river below Cameo enters the Grand Valley where intense agricultural irrigation occurs. The Mancos Shale is the predominant rock in the valley with overlying Tertiary terrestrially deposited rocks high in the tributary drainages. The water type is mixed (fig. 4); however, during high-water flow, the river is closer to a calcium bicarbonate type, and during irrigation and base flow, sodium and sulfate occur in greater proportions. Selenium concentrations are at the State of Colorado's freshwater chronic standard of $4.6 \mu \mathrm{g} / \mathrm{L}$ during the three flow regimes (table $\mathrm{AI}-3$ ). The $\mathrm{Ca}: \mathrm{SO}_{4}$ ratio (table 24) decreases to one during irrigation and base flow, suggesting that dissolution of gypsum occurs during these flow conditions. The $\mathrm{Ca}: \mathrm{SO}_{4}$ ratio is slightly higher than one during high-water flow and is likely due to a mixture of higher ratios in upstream Colorado River water and ratios of about one in Gunnison River water. The Na:Cl ratios are near two (table 24), reflecting the high ratios in the Gunnison River and Plateau Creek. Isotopes of sulfate (see fig. 16 in Geochemical Evolution of the Colorado River Above Cisco) support a mixture of sulfate derived from dissolution of salts in the Mancos Shale and sulfate derived upstream from the Grand Valley (Colorado River near Cameo).

\section{Colorado River Near Cisco, Utah}

The Dolores River enters the Colorado River upstream from our most downstream sampling station on the Colorado River (near Cisco). There are no reservoirs along this stretch of the Colorado River. In this area, the geology is dominated by Jurassic and Triassic sedimentary rocks. The Mancos Shale does crop out in some of the smaller tributary drainages to the north of the river. The water is a mixed type throughout the year (fig. 4). Additional loading of solutes from the State-line station to this station is due to input from the Dolores River and is most evident during high-water flow and is relatively insignificant during other times of the year. During high water, the $\mathrm{Ca}: \mathrm{SO}_{4}$ ratio (table 25) at this station is lower than in the Dolores River (table 18) and at the State-line station (table 24). The sulfate isotopes during high-water flow (see fig. 16 in Geochemical Evolution of the Colorado River Above Cisco) are within the range expected for mixing of the Dolores River and upstream Colorado River waters, so the additional sulfate would have to be from a

Table 21. Summary of geochemical parameters for the Colorado River near Cameo.

[HW, high-water flow; IRR, irrigation flow; BF, base flow; CR, Colorado River]

\begin{tabular}{lccc}
\hline \multicolumn{1}{c}{$\begin{array}{c}\text { Colorado River, } \\
\text { Cameo }\end{array}$} & HW & IRR & BF \\
\hline Charge balance (percent) & -2 & -2 & -0.4 \\
Conductivity $(\mu \mathrm{S} / \mathrm{cm})$ & 395 & 525 & 920 \\
Water type & $\mathrm{Ca}-\mathrm{HCO}_{3}$ & mixed & mixed \\
Load (tonnes solutes/day) & 7,450 & 4,170 & 3,870 \\
Percent CR load at Cisco & 44 & 51 & 40 \\
$\mathrm{Ca}: \mathrm{SO}_{4}$ (molar basis) & 2.3 & 1.8 & 1.4 \\
$\mathrm{Na}$ Cl (molar basis) & 1.4 & 1.3 & 1.3 \\
Evaporation & no & no & no \\
Predominant $\mathrm{SO}_{4}$ source & $?$ (see text) & evaporites & evaporites \\
\hline
\end{tabular}


Table 22. Sulfate loads and isotopic composition of contributions between the stations above Glenwood Springs and near Cameo on the upper Colorado River.

[HW, high-water flow; Irr, irrigation flow; BF, base flow; CR, Colorado River; V-CDT, Vienna Cañon Diablo Troilite]

\begin{tabular}{|c|c|c|c|c|c|c|}
\hline \multirow[t]{2}{*}{ Station } & \multicolumn{3}{|c|}{$\begin{array}{c}\mathrm{SO}_{4} \text { load } \\
\text { (tonnes/day) }\end{array}$} & \multicolumn{3}{|c|}{$\begin{array}{c}\delta^{34} S_{\text {s04 }} \% \\
\text { (V-CDT) }\end{array}$} \\
\hline & HW & Irr & BF & HW & Irr & BF \\
\hline Colorado River above Glenwood Springs ${ }^{1}$ & 360 & 295 & 245 & 2.3 & 6.0 & 6.7 \\
\hline Roaring Fork, Glenwood Springs & 335 & 255 & 215 & 7.2 & 8.9 & 9.5 \\
\hline Colorado River near Cameo & 1,160 & 775 & 700 & 5.9 & 6.7 & 7.9 \\
\hline Unknown source & 430 & 190 & 205 & 7.1 & 3.4 & 6.5 \\
\hline
\end{tabular}

${ }^{1}$ Includes sulfate load from hot springs near Dotsero.

${ }^{2}$ Calculated from data in Eisenhaur (1983) and from this study. Flow and composition of spring water are assumed to be constant during the year.

Table 23. Summary of geochemical parameters for Plateau Creek near Cameo.

[HW, high-water flow; IRR, irrigation flow; BF, base flow; CR, Colorado River]

\begin{tabular}{lccc}
\hline \multicolumn{1}{c}{$\begin{array}{c}\text { Plateau Creek, } \\
\text { Cameo }\end{array}$} & HW & IRR & BF \\
\hline Charge balance (percent) & 1 & 3 & 2 \\
Conductivity $(\mu \mathrm{S} / \mathrm{cm})$ & 195 & 520 & 590 \\
Water type & $\mathrm{Ca}-\mathrm{HCO}_{3}$ & $\mathrm{Ca}^{-\mathrm{HCO}_{3}}$ & $\mathrm{Ca}-\mathrm{HCO}_{3}$ \\
Load (tonnes solutes/day) & 575 & 175 & 190 \\
Percent CR load at Cisco & 3 & 2 & 2 \\
$\mathrm{Ca}: \mathrm{SO}_{4}$ (molar basis) & 5.5 & 3.8 & 2.8 \\
$\mathrm{Na} \mathrm{Cl}$ (molar basis) & 5.8 & 7.5 & 7.7 \\
Evaporation & no & no & no \\
Predominant $\mathrm{SO}_{4}$ source & Basalt & Basalt & Basalt \\
\hline
\end{tabular}

similar source as that in the Dolores and upstream Colorado Rivers. The $\mathrm{Na}: \mathrm{Cl}$ ratios (tables 18,24 , and 25) indicate that dissolution of sodium sulfates similar to those found upstream may be added along this river stretch explaining the anomalously low $\mathrm{Ca}: \mathrm{SO}_{4}$ ratio.

\section{Geochemical Evolution of the Colorado River Above Cisco}

In the headwaters of the upper Colorado River, the water is a $\mathrm{Ca}-\mathrm{HCO}_{3}$ type (fig. 4). The water type does not change dramatically during high-flow conditions. During irrigation and base flow, however, the water evolves toward a calcium chloride type as it flows through the Eagle Valley Evaporite and toward a calcium sulfate type as it flows through the Mancos Shale. From its headwaters to the station near Cisco, Utah, the conductivity of the Colorado River throughout our sampling transect increases between 3.4 and 6 times, while the load increases between 22 and 50 times (fig. 15). The load during high-water flow is much greater than during other times of the year because the flow is so much greater; loads during irrigation and base flow are nearly identical. The Gunnison River during high-water flow adds the greatest load to the Colorado River. In the upper portion of the study area $(0$ to $250 \mathrm{~km})$, loads increase more or less linearly with distance. Starting at Cameo, loads added per kilometer of river increase at a greater rate as the river and its tributaries flow through the Mancos Shale and as the amount of irrigated land increases.

During high water, the Colorado River carries sediment rich in $\mathrm{Al}$ and $\mathrm{Fe}$ oxides, accounting for the greater available trace-metal concentrations (table AI-3). Aqueous Se concentrations exceed the Colorado freshwater chronic standard of $4.6 \mu \mathrm{g} / \mathrm{L}$ at downstream stations during base flow.

The isotopes of water (fig. 16) fall along the GMWL trend indicating that evaporation does not significantly affect the salt load in the upper Colorado River above Cisco (fig. 16). Evolution of the isotopes of sulfate (fig. 16) dissolved in the Colorado River is systematic and depends on the geologic formation through which it is flowing. There appear to be three main sources of sulfate - sulfate derived from crystalline rock formations similar to those in the headwaters (starting composition, fig. 16), the Eagle Valley Evaporite, and the Mancos Shale. Mixing between starting composition and Eagle Valley Evaporite is evident in the Colorado River below Kremmling to Cameo, in the Eagle River, and the Roaring Fork River. The impact of the Mancos Shale on the sulfate load in the Colorado River below Cameo and in the Gunnison River is dramatic as shown by the shift in the sulfate isotopes (fig. 16).

Table 24. Summary of geochemical parameters for the Colorado River near the Colorado-Utah State line.

[HW, high-water flow; IRR, irrigation flow; BF, base flow; CR, Colorado River]

\begin{tabular}{lccc}
\hline $\begin{array}{c}\text { Colorado River, } \\
\text { Colorado-Utah State line }\end{array}$ & HW & IRR & BF \\
\hline Charge balance (percent) & -2 & -4 & -9 \\
Conductivity $(\mu \mathrm{S} / \mathrm{cm})$ & 435 & 685 & 1,090 \\
Water type & mixed & mixed & mixed \\
Load (tonnes solutes/day) & 13,900 & 8,550 & 8,420 \\
Percent CR load at Cisco & 82 & 105 & 87 \\
$\mathrm{Ca}: \mathrm{SO}_{4}$ (molar basis) & 1.4 & 1.1 & 1.1 \\
$\mathrm{Na} C \mathrm{Cl}$ (molar basis) & 2.1 & 1.9 & 2.1 \\
Evaporation & no & no & no \\
Predominant $\mathrm{SO}_{4}$ source & Mancos & Mancos & Mancos \\
& Shale & Shale & Shale \\
\hline
\end{tabular}


Table 25. Summary of geochemical parameters for the Colorado River near Cisco.

[HW, high-water flow; IRR, irrigation flow; BF, base flow; CR, Colorado River]

\begin{tabular}{lccc}
\hline \multicolumn{1}{c}{$\begin{array}{c}\text { Colorado River, } \\
\text { Cisco }\end{array}$} & HW & IRR & BF \\
\hline Charge balance (percent) & 10 & 0.8 & -10 \\
Conductivity $(\mu \mathrm{S} / \mathrm{cm})$ & 430 & 725 & 1,230 \\
Water type & mixed & mixed & mixed \\
Load (tonnes solutes/day) & 17,000 & 8,170 & 9,580 \\
Percent CR load at Cisco & 100 & 100 & 100 \\
$\mathrm{Ca}: \mathrm{SO}_{4}$ (molar basis) & 1.1 & 0.99 & 0.98 \\
$\mathrm{Na} C \mathrm{Cl}$ (molar basis) & 1.5 & 1.5 & 1.8 \\
Evaporation & no & no & no \\
Predominant $\mathrm{SO}_{4}$ source & Mancos & Mancos & Mancos \\
& Shale & Shale & Shale \\
\hline
\end{tabular}

\section{Fingerprinting Major Geologic Salt Sources}

Major geologic influences on the chemistry of the Colorado River are evident in the evolution of the water from a calcium bicarbonate type near its headwaters (weathering of crystalline rocks) toward a sodium chlorite type as it flows through Eagle Valley Evaporite that includes halite, toward a calcium sodium sulfate type as it and tributaries flow through the sulfate-rich Mancos Shale and bedded evaporites (halite and anhydrite) of the Paradox Formation. Sodium, chloride, calcium, and sulfate loads and sulfur isotopic compositions have been used to fingerprint these major salt contributors and to quantitatively determine their relative influence on solutes in the Colorado River.
Chloride is generally a minor contributor to salt loads in the upper Colorado River, accounting for only 6 to 14 percent of the total solute load at the Colorado River station near Cisco. It is less than 5 percent of the load at any one station except for those where the river flows through Eagle Valley Evaporite (Eagle River, Roaring Fork River, Colorado River headwater, and Colorado River headwater-plateau watersheds), or Paradox Formation evaporites (upper and lower Dolores River watersheds). At stations within these watersheds, values increase from 5 percent of the total load during high-water flow in the Dolores River to over 40 percent during irrigation flow. Although 40 percent is a high proportion of the total load, the contribution of chloride at this station to the load in the upper Colorado River near Cisco is still only 2 percent.

Sulfate, on the other hand, is a major contributor, accounting for 25 to 30 percent of the solute load in the Colorado River near Cisco. In watersheds containing significant expanses of Mancos Shale (Gunnison and Uncompahgre Rivers), sulfate makes up nearly half of the total load. Although most sulfate comes from gypsum, some sulfate is derived from the dissolution of anhydrite and thenardite. In most cases, we are not able to constrain how much of the sulfate came from each mineral. Therefore, all mineral weights are reported on a gypsum basis. If all sulfate is derived from anhydrite, then using gypsum values results in an overestimation of 20 percent of the amount of mineral dissolved. If all is from thenardite, we overestimated the amount by 17 percent.

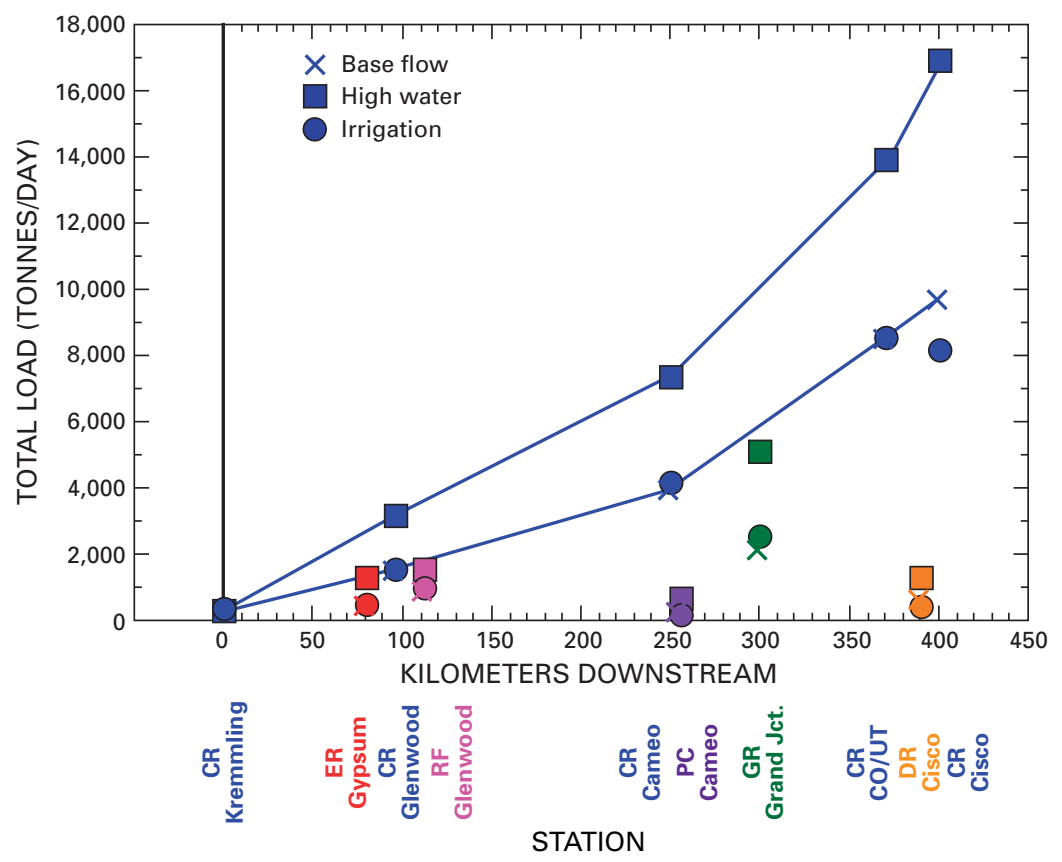

Figure 15. Total load at stations along the Colorado River and at confluences with tributaries. River kilometers are estimated distance from the Colorado River near Kremmling, Colo., station. CR, Colorado River; ER, Eagle River, RF, Roaring Fork River; PC, Parachute Creek; GR, Gunnison River; and DR, Dolores River. 

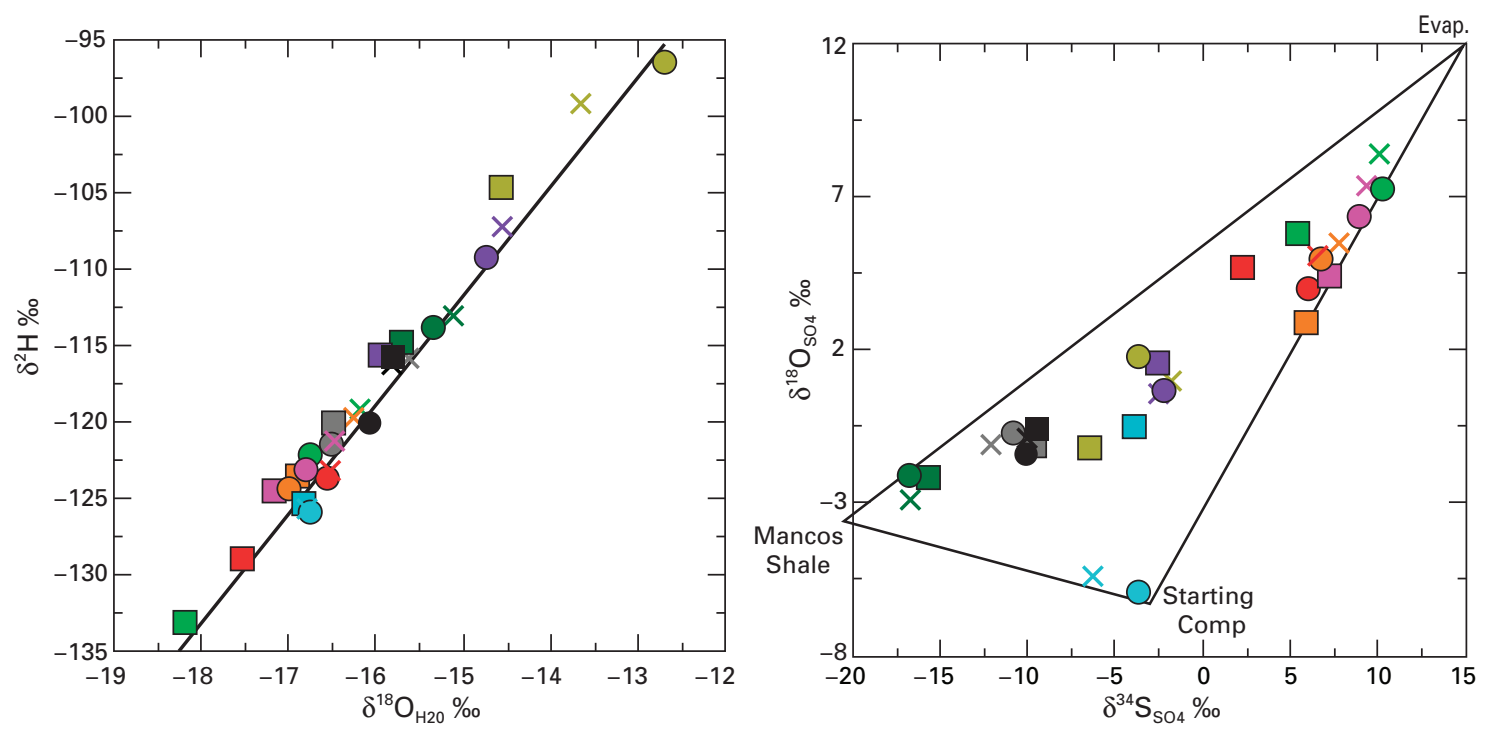

EXPLANATION

$\begin{array}{ll}\times & \text { CR-Kremmling, BF } \\ \times & \text { ER-Gypsum, BF } \\ \times & \text { CR-Glenwood Spg., BF } \\ \times & \text { RF-Glenwood Spg., HW } \\ \times & \text { CR-Cameo, BF } \\ \times & \text { PC-Cameo, BF } \\ \times & \text { GR-Grand Jct, BF } \\ \times & \text { CR-Utah-Colo., BF } \\ \times & \text { DR-Cisco, BF } \\ \times & \text { CR-Cisco, BF }\end{array}$

CR-Kremmling, Irr
ER-Gypsum, Irr
CR-Glenwood Spg.,Irr
RF-Glenwood Spg., HW
CR-Cameo, Irr
PC-Cameo, Irr
GR-Grand Jct, Irr
CR-Utah-Colo., Irr
DR-Cisco, Irr
CR-Cisco, Irr

$\begin{array}{ll}\square & \text { CR-Kremmling, HW } \\ \square \quad \text { ER-Gypsum, HW } \\ \text { CR-Glenwood Spg., HW } \\ \square \quad \text { RF-Glenwood Spg., HW } \\ \square \quad \text { CR-Cameo, HW } \\ \square \quad \text { PC-Cameo, HW } \\ \square \quad \text { GR-Grand Jct, HW } \\ \square \quad \text { CR-Utah-Colo., HW } \\ \square \quad \text { DR-Cisco, HW } \\ \text { CR-Cisco, HW }\end{array}$

Figure 16. Isotopic composition of water and sulfate along the main stem of the upper Colorado River at and above Cisco and at farthest downstream stations of major tributaries. Solid line connects the starting composition and two major sources of sulfate to the Colorado RiverStarting Comp, starting composition at Kremmling station (farthest upstream on Colorado River); evap., evaporites (Eagle Valley Evaporite); and Mancos Shale. CR, Colorado River; ER, Eagle River, RF, Roaring Fork River; PC, Parachute Creek; GR, Gunnison River; DR, Dolores River; HW, high-water flow; Irr, irrigation flow; BF, base flow. In the case of the Dolores River, the evaporite contribution is from the Paradox Formation with a similar isotopic composition to that in the Eagle Valley Evaporite. Hydrogen and oxygen isotopes reported relative V-SMOW and sulfur isotopes relative to $\mathrm{V}$-CDT.

\section{Evaporites in the Eagle Valley Evaporite}

The major input of chloride to the Colorado River is dissolution of halite related to the Eagle Valley Evaporite upstream from Cameo. Based on our limited sampling, we estimate that 1,210 tonnes of halite dissolve per day contributing $\mathrm{Cl}$ to the Colorado River during high-water flow, 1,060 tonnes of halite per day during irrigation flow, and 1,340 tonnes of halite per day during base flow. ${ }^{7}$ These values are fairly similar, and if we assume their average represents an average daily contribution, then 439,000 tonnes of halite in the Eagle Valley Evaporite are dissolved and added to the Colorado River annually. Using sulfate loads and isotopic compositions, we estimate that at least 345,000 tonnes of gypsum from the Eagle Valley Evaporite are dissolved and added annually as well. The total amount of solutes derived from these evaporites as estimated in this study is 784,000 tonnes solutes/year (18 percent of the estimated annual load of the Colorado River at Cisco). Chafin and Butler (2002) derived an estimate of 817,000 tonnes/year using a very different approach. Considering the number of assumptions in both approaches and that the data are from different years, these estimates are very similar.

\section{Evaporites in the Paradox Formation}

A similar analysis was used to determine the amount of salt derived from the Paradox Formation in the upper Dolores River watershed. Assuming that 58 percent of the chloride in the Dolores River at Bedrock comes from dissolution of halite (load at Bedrock minus load calculated for McPhee Reservoir), 60 tonnes of halite per day are dissolved and added to the river during high flow. During irrigation and base-flow conditions, 100 percent of the $\mathrm{Na}$ and $\mathrm{Cl}$ is assumed to have been derived from halite as the load from the McPhee Reservoir is negligible. Under these conditions, 115 and 35 tonnes of halite per day, respectively, dissolve and enter the river. Assuming that the average of these three amounts estimates a daily average throughout the year, 25,600 tonnes of Paradox Formation halite dissolve per year upstream from the Bedrock station. Calculations indicate that between

${ }^{7}$ Estimates based on $\mathrm{Cl}$ loads in the Colorado River at Cameo, Colo., minus loads for the Colorado River near Kremmling, Colo., and Eagle River near Minturn, Colo. 
the Bedrock and Cisco stations, a portion of the load of the Dolores River is lost during high- and irrigation-flow conditions. This loss may be due to recharge of the alluvium aquifer of the Paradox Valley (Chafin, 2003). Under base-flow conditions in the year we sampled, sodium and chloride increase dramatically in a molar ratio of one. This increase suggests that during base flow, additional solutes from the dissolution of 215 tonnes of halite per day are added to the river between these two stations (loads adjusted to exclude solutes carried by the San Miguel River). Assuming base-flow conditions for a third of the year, this amount is equal to 26,200 tonnes of halite. The total amount of Paradox halite dissolved and solutes added to the Dolores River from McPhee Reservoir to Cisco is estimated at 51,800 tonnes per year.

The Paradox Formation evaporites also include bedded anhydrite that contributes to the calcium and sulfate load along the Dolores River. Sulfate isotopes were used to determine the relative contribution of Paradox anhydrite $\left(\delta^{34} \mathrm{~S}\right.$ of $13 \%$ and $\delta^{18} \mathrm{O}$ of around $16 \%$; Claypool and others, 1980; Tuttle and others, 1996). Dissolution of anhydrite in the Paradox Formation above the Bedrock station is small, consistent with findings reported in Chafin (2003). Sulfate isotopes indicate that negligible dissolution of anhydrite occurs during highwater flow. During irrigation flow and base flow, solutes from the dissolution of 12 and 8 tonnes anhydrite per day, respectively, are added to the Dolores River. An average of these daily rates indicates that about 2,430 tonnes of anhydrite dissolve in a year ( 3,100 tonnes per year on a gypsum basis).

During high water, the loss of a portion of the Dolores River flow across the Paradox Valley precludes calculation of contributions of specific salts; however, sulfate isotopes at the Cisco station indicate that 90 percent of the sulfate is acquired from the San Miguel River and 10 percent from upstream. During irrigation and base flow, the sulfate load at Cisco is equal to the sum of the load at the Bedrock and the San Miguel stations, indicating that negligible sulfate is acquired as the Dolores River crosses the Paradox Valley. Sulfate loads indicate that 81 (irrigation flow) and 90 (base flow) percent of the sulfate in the Dolores River is from San Miguel River flow.

\section{Salts Derived From Weathering of the Mancos Shale}

Gypsum and highly soluble thenardite $\left(\mathrm{Na}_{2} \mathrm{SO}_{4}\right)$ are common weathering products associated with the Mancos Shale. Both salts are found in soils derived from the shale. Gypsum is also found along fractures and bedding planes in shale in the unsaturated zone. This deeper gypsum is thought to be related to historic weathering of the shale when the water table was higher and/or the climate wetter (Tuttle and others, 2008). The sulfur isotopes of all salt are very similar to that of pyrite in the Mancos Shale (average of $-21 \%$ ), but the $\delta^{18} \mathrm{O}$ of the deeper gypsum is isotopically lighter $(-10 \%)$ than the sulfate salts found in the soil $(-3 \%)$ (Tuttle and others, 2005).
In the Dolores River watershed, we had good control on the source of sodium, and we were able to determine sulfate derived from gypsum and sulfate derived from thenardite. In all the other watersheds, however, we were unable to differentiate between sulfate derived from these two minerals; therefore, all Mancos Shale calculations in these watersheds and totals at our most downstream station were made on a gypsum basis, realizing that some of the sulfate is indeed from dissolution of thenardite.

\section{Dolores River Watershed}

In the Dolores River watershed, a portion of the sulfate is derived from the Mancos Shale. By assuming that the sodium acquired between the McPhee Reservoir and the Bedrock station during high-water flow, and not attributed to halite, is from dissolution of salt in the Mancos, we can calculate the amount of thenardite $\left(\mathrm{Na}_{2} \mathrm{SO}_{4}\right)$ separately from the gypsum. Calculations indicate that dissolution of 64 tonnes of thenardite per day ( $78 \mathrm{t} / \mathrm{d}$ gypsum equivalent) is needed to supply this sodium load. Dissolution of 57 tonnes of gypsum per day accounts for the remainder of the sulfate load acquired between these two points during high-water flow. Isotopic composition of this sulfate indicates that it comes from Mancos soil. During irrigation flow and base flow, thenardite does not contribute salt to the Dolores River, but gypsum along bedding planes deeper in the Mancos Shale does. Isotopes indicate that 40 and 30 percent, respectively, of the sulfate load at the Bedrock station comes from dissolution of 8 tonnes of gypsum per day during irrigation flow and 3 tonnes of gypsum per day during base flow.

It appears that gypsum in the Mancos Shale soil also contributes sulfate to the San Miguel River (estimated 15 percent at our sampling station). This percentage translates to 66,25 , and 24 tonnes of gypsum per day being dissolved and solutes added to the river during high-water, irrigation, and base flows, respectively. It is possible that, during highwater flow, some of the sulfate may come from thenardite as well, although we have no way to quantify the amount. During high-water flow, dissolution of 200 tonnes of gypsum per day is needed to account for the sulfate load in the Dolores River attributed to the Mancos Shale. This amount drops dramatically to 33 and 27 tonnes per day during irrigation and base flow, respectively. Based on an average daily rate, this represents 31,600 tonnes of gypsum per year.

\section{Gunnison River Watershed}

About half of the solutes and most of the sulfate in the Gunnison River are derived from weathering of the Mancos Shale. Using sulfate isotopes, we calculate that during high water, 87 percent of the sulfate in the Uncompahgre River at Delta is derived from Mancos Shale. During irrigation and base flow, the proportions increase slightly to 90 and 89 percent respectively. Using the same method, we calculate 
that 88,90 , and 95 percent of the sulfate in the Gunnison River at Delta during high-water, irrigation, and base flows, respectively, is from Mancos Shale. The amount of gypsum dissolution required to supply this sulfate at the Uncompahgre and Gunnison Rivers confluence a short distance downstream from these two stations is 2,190 (high-water flow), 2,410 (irrigation flow), and 2,120 (base flow) tonnes of gypsum per day. Again, assuming that the average of the amounts during different flow conditions approximates the daily average throughout the year, dissolution of 817,600 tonnes of gypsum is required to supply the sulfate.

During high-water flow, additional sulfate is picked up by the Gunnison River between the confluence with the Uncompahgre River and the Gunnison River near Grand Junction station. Isotopic composition of the sulfate indicates that most of it is from Mancos soil and represents an additional dissolution of 830 tonnes of gypsum per day. During irrigation and base-flow conditions, 22 and 29 percent of the sulfate load is lost over this reach due to alluvium recharge or diversion with no return. Summing the amount of sulfate in the Gunnison River at Delta and in the Uncompahgre River, adding in the sulfate acquired below their confluence during high-water flow, and subtracting that lost during irrigation and base flow, we calculate an average of 1,190 tonnes of sulfate per day from Mancos Shale was supplied to the Colorado River by the Gunnison River. This represents the dissolution of an estimated 777,500 tonnes of Mancos Shale gypsum per year (from base-flow data for Gunnison and Uncompahgre Rivers at Delta), 224,500 tonnes of which was lost to assumed alluvial recharge in the lower Gunnison River stretch. Warner and others (1985) used data from 1977-78 to calculate that the Gunnison River base flow contributed 736,000 tonnes of solutes per year. Using just our base-flow data, we calculate 773,400 tonnes of solutes per year, a value that agrees well with Warner and others (1985).

\section{Colorado River Headwater-Plateau Watershed}

As the Colorado River enters the Grand Valley (reach below Cameo station), it flows through a landscape dominated by Mancos Shale. The Colorado River provides irrigation water that supports extensive agriculture on Mancos Shale in the valley. We estimate from sulfate isotopes that 62 (highwater flow), 67 (irrigation flow), and 65 (base flow) percent of the sulfate load at the Colorado-Utah State line station is derived from Mancos Shale soil. Using these percentages and the sulfate loads at this station, minus the sulfate loads of the Gunnison River at Grand Junction attributed to the Mancos Shale, we calculate a minimum of 1,190, 1,520, and 2,150 tonnes of gypsum per day dissolved in the Grand Valley and contributed sulfate to the Colorado River during highwater, irrigation, and base flows, respectively. These values are minimums as some of the sulfate load may have been removed during recharge of alluvium. Assuming the average of these amounts reasonably estimates the daily average throughout the year, then 591,700 tonnes of gypsum in the Grand Valley dissolved and the solutes were added to the Colorado River in 2005.

\section{Summary}

In 2005, the amount of salt (halite and gypsum) dissolved from the Eagle Valley Evaporite, Paradox Formation, Mancos Shale, and their associated soils is shown in table 26. Collectively, dissolution of these salts account for just over half of the solutes in the Colorado River at the station near Cisco. The Mancos Shale generates about 33 percent of the solutes, the Eagle Valley Evaporite generates 18 percent of the solutes, and the Paradox Formation generates only 1 percent.

Table 26. The 2005 estimated dissolution rates for halite and gypsum in the Eagle Valley, Paradox, and Mancos Formations estimated in this study and a comparison of the derived solutes to the estimated annual Colorado River (CR) load at Cisco.

\begin{tabular}{lccc}
\hline \multicolumn{1}{c}{ Formation } & $\begin{array}{c}\text { Halite } \\
\text { (tonnes/a) }\end{array}$ & $\begin{array}{c}\text { Gypsum } \\
\text { (tonnes/a) }\end{array}$ & $\begin{array}{c}\text { Percent of } \\
\text { CR annual load } \\
\text { (Cisco) }\end{array}$ \\
\hline Eagle Valley Evaporite & 439,000 & 343,000 & 18 \\
Paradox Formation & 51,800 & 3,100 & 1 \\
Mancos Shale, total & $1,400,800$ & 33 \\
$\quad$ Dolores River & 31,600 & 1 \\
$\quad$ Gunnison River & $777,500^{1}$ & 18 \\
Colorado River & 591,700 & 14 \\
$\quad$ headwater/plateau & & \\
\hline \multicolumn{1}{l}{ An estimated 40,200 tonnes per year of additional gypsum dissolved } \\
and the sulfate removed from the Gunnison River between Delta and Grand \\
Junction stations during irrigation and base-flow conditions due to alluvium \\
recharge or water diversion.
\end{tabular}

\section{Acknowledgments}

The authors wish to thank Patrick Lambert, District Chief of the Utah Water Science Center, and Paul von Guerard (retired) and Greg O'Neill, Chiefs for Grand Junction and Lakewood USGS Colorado Water Science Center field offices, respectively. Without the field support of Patricia Solberg, Ron Tibbetts, Clay Thompson, and David Grey (USGS), this study would not have been possible. We wish to thank U.S. Department of Energy personnel for obtaining ground-water samples from the Rifle mill site, especially Richard Bush, Dick Dayvault, Dave Traub, and Emile Better; Stephen Onorofskie for arranging sampling of gypsum from the American Gypsum mines in the Eagle Valley Evaporite; and Tonya Hammond for arranging access to the Snow Cap Coal Company property. Thanks to Cyrus Berry (USGS) for help with logistics and Bridget Ball (USGS) for GIS support. The manuscript benefited greatly from the thoughtful reviews of Richard Wanty and Paul von Guerard. 


\section{References Cited}

Chafin, D.T., 2003, Effect of the Paradox Valley unit on the dissolved-solids load of the Dolores River near Bedrock, Colorado, 1988-2001: U.S. Geological Survey WaterResources Investigation Report 02-4275, 6 p.

Chafin, D.T., and Butler, D.L., 2002, Dissolved-solids-load contributions of the Pennsylvanian Eagle Valley Evaporite to the Colorado River, west-central Colorado, in Geological Society of America Special Paper 366: Boulder, Colo., Geological Society of America, p. 149-156.

Claypool, G.E., Holser, W.T., Kaplan, I.R., Sakai, H., Zak, I., 1980, The age curves of sulfur and oxygen isotopes in marine sulfate and their mutual interpretation: Chemical Geology, v. 28, p. 199-260.

Colorado Department of Public Health and Environment (CDPHE), 2003, Classifications and numeric standards for lower Colorado River basin: available at http:/www.epa.gov/ waterscience/standards/wqslibrary/co/reg37-20050120.pdf.

Craig, H., 1961, Isotope variation in meteoric waters: Science, v. 133, p. $1,702-1,703$.

Day, W.C., Green, G.N., Knepper, D.H., Jr., and Phillips, R.C., 1999, Spatial geologic data model for the Gunnison, Grand Mesa, Uncompahgre National Forests mineral resource assessment area, southwestern Colorado, and digital data for the Leadville, Montrose, Durango, and Colorado parts of the Grand Junction, Moab, and Cortez $1^{\circ} \times 2^{\circ}$ geologic maps: U.S. Geological Survey Open-File Report 99-427, $32 \mathrm{p}$.

Eisenhauer, R.J., 1983, Characterization of Glenwood Springs and Dotsero Springs water: Bureau of Reclamation Report REC-ERC 83-10, 52 p.

Environmental Protection Agency (EPA), 2006, Current National recommended water quality criteria: available at http://www.epa.gov/waterscience/criteria/wqcriteria.html.

Flynn, J.L., 2003, Ground-water-quality assessment of shallow aquifers in the Front Range Urban Corridor, Colorado, 1954-98: U.S. Geological Survey Water-Resources Investigations Report 02-4247, 32 p.

Giesemann, A., Jäger, H.J., and Feger, K.H., 1995, Evaluation of sulphur cycling in managed forest stands by means of stable S-isotope analysis: Plant and Soil, v. 168-169, p. 399-404.
Hintz, L.F., Willis, G.C., Laes, D.Y.M., Sprinkel, D.A., and Brown, K.D., 2000, Digital geologic map of Utah: Salt Lake City, Utah Geological Survey in cooperation with the U.S. Geological Survey, Map 179DM.

Nordstrom, D.K., Winfield, G.W., Mast, M.A., Bove, D.J., and Rye, R.O., 2007, Aqueous sulfate stable isotopes-A study of mining-affected and undisturbed acidic drainage, in Church, S.E., von Guerard, P., and Finger, S.E., eds., Integrated investigations of environmental effects of historical mining in the Animas River watershed, San Juan County, Colorado: U.S. Geological Survey Professional Paper 1651-E8, p. $387-418$.

Plummer, L.N., Bexfield, L.M., Anderholm, S.K., 2003, How ground-water chemistry helps us understand the aquifer, in Bartollino, J.R., and Cole, J.C., eds., Ground-water resources of the Middle Rio Grande basin: U.S. Geological Survey Circular 1222, p. 91-100.

Serageldin, I., 2000, World's rivers in crisis: some are dying; others could die: World Commission on Water for the 21st Century, available at http://www.worldwatercouncil.org/ Vision/6902B03438178538C125683A004BE974.htm.

Spahr, N.E., Apodaca, L.E., Deacon, J.R., Bails, J.B., Bauch, N.J., Smith, C.M., and Driver, N.E., 2000, Water quality in the upper Colorado River basin, Colorado, 1996-98: U.S. Geological Survey Circular 1214, 33p.

Taggert, J.E., Jr., ed., 2002, Analytical methods for chemical analysis of geologic and other materials, U.S. Geological Survey: U.S. Geological Survey Open-File Report 02-0223 [variously paged].

Taylor, B.E., and Wheeler, M.C., 1994, Sulfur- and oxygenisotope geochemistry of acid mine drainage in the Western United States - Field and experimental studies revisited, in Alpers, C.N., and Blowes, D.W., eds., Environmental geochemistry of sulfide oxidation: Washington, D.C., American Chemical Society, p. 481-514.

Tuttle, M.L.W., Breit, G.N., Fahy, J., Goldhaber, M.B., Grauch, R.I., 2008, Trace-metal accumulation in regolith derived from black shale in humid and semi-arid weathering regimes, U.S.A.: 2008 Geological Society of America Joint Annual Meeting, Abstracts with Program, 325-12, CD-ROM.

Tuttle, M.L., Klett, T.R., Richardson, M., and Breit, G.N., 1996, Geochemistry of two interbeds in the Pennsylvanian Paradox Formation, Utah and Colorado-A record of deposition and diagenesis of repetitive cycles in a marine basin: U.S. Geological Survey Bulletin 2000-N, 86 p. 
Tuttle, M.L.W., Fahy, J.W., Grauch, R.I., and Stillings, L.L., 2005, Salt and selenium from Mancos Shale, Uncompahgre River basin, southwestern Colorado, U.S.A., in International salinity forum-Managing saline soils and water: Riverside, Calif., Science, Technology, and Social Issues, April 2005, p. $457-460$.

Tuttle, M.L., Goldhaber, M.B., and Williamson, D.L., 1986, An analytical scheme for determining forms of sulphur in oil shales and associated rocks: Talanta, v. 33, p. 953-961.

Tuttle, M.L., and Goldhaber, M.B., 1993, Sedimentary sulfur geochemistry of the Paleogene Green River Formation, western U.S.A.: Implications for interpreting depositional and diagenetic processes in saline alkaline lakes: Geochimica et Cosmochimica Acta, v. 57, p. 3,023-3,039.
Vengosh, A., 2004, Salinization and saline environments, in Holland H.D., and Turekian K.K., eds., Treatise on geochemistry, v. 5: New York, Elsevier, p. 330-365.

Warner, J.W., Heimes, F.J., and Middelburg, R.F., 1985, Ground-water contribution to the salinity of the upper Colorado River basin: U.S. Geological Survey Water-Resources Investigations Report 84-4198, 113 p.

U.S. Department of Interior, 2005, Quality of water, Colorado River basin progress report no. 22: Denver, Colo., Bureau of Reclamation, 69 p., available at $h t t p: / / w w w . u s b r . g o v / u c /$ progact/salinity/index.html.

U.S. Water News, 1995, Congress considers Colorado River salt problem: available at http://www.uswaternews.com/ archives/arcpolicy/5color.html. 


\section{Appendixes}




\section{Appendix I. Chemical and Isotopic Data for All Water Samples Collected in This Study}

Table A1-1. Metadata (analytical method, detection limit, the number of samples with censored data, the percent of samples with replaced values, and the replacement value) for reported concentrations. Replacement (red) values ( $0.5 \times$ detection limit) are used when censored values were reported for $\leq 20$ percent of the samples (14 samples or less). For elements with the number censored = "many," less than concentrations are reported.

[IC, ion chromatography; ICP-MS, inductive coupled plasma-mass spectrometry; ICP-AES, inductive coupled plasma-atomic emission spectrometry; na, not analyzed]

\begin{tabular}{|c|c|c|c|c|c|}
\hline Element & Method & Detection limit & No. censored & Percent replaced & Replacement \\
\hline $\mathrm{NO}_{3}$ & $\mathrm{IC}$ & $0.08 \mathrm{mg} / \mathrm{L}$ & 14 & 20 & $0.04 \mathrm{mg} / \mathrm{L}$ \\
\hline $\mathrm{Al}$ & ICP-AES & $10 \mu \mathrm{g} / \mathrm{L}$ & many & na & \\
\hline $\mathrm{Cd}$ & ICP-MS & $0.02 \mu \mathrm{g} / \mathrm{L}$ & many & na & \\
\hline $\mathrm{Cd}$ (raw) & ICP-MS & & 6 & 10 & $0.01 \mu \mathrm{g} / \mathrm{L}$ \\
\hline $\mathrm{Ce}$ & ICP-MS & $0.01 \mu \mathrm{g} / \mathrm{L}$ & 8 & 13 & $0.005 \mu \mathrm{g} / \mathrm{L}$ \\
\hline Co (raw) & ICP-MS & $0.02 \mu \mathrm{g} / \mathrm{L}$ & 1 & 2 & $0.01 \mu \mathrm{g} / \mathrm{L}$ \\
\hline $\mathrm{Cr}$ & ICP-MS & $0.1 \mu \mathrm{g} / \mathrm{L}$ & many & na & \\
\hline $\mathrm{Cr}$ (raw) & ICP-MS & $0.1 \mu \mathrm{g} / \mathrm{L}$ & many & na & \\
\hline $\mathrm{Cs}$ & ICP-MS & $0.02 \mu \mathrm{g} / \mathrm{L}$ & many & na & \\
\hline Cs (raw) & ICP-MS & $0.02 \mu \mathrm{g} / \mathrm{L}$ & 9 & 14 & $0.01 \mu \mathrm{g} / \mathrm{L}$ \\
\hline Dy & ICP-MS & $0.005 \mu \mathrm{g} / \mathrm{L}$ & many & na & \\
\hline $\mathrm{Eu}(\mathrm{raw})$ & ICP-MS & $0.005 \mu \mathrm{g} / \mathrm{L}$ & 2 & 3 & $0.003 \mu \mathrm{g} / \mathrm{L}$ \\
\hline $\mathrm{Fe}$ & ICP-MS & $50 \mu \mathrm{g} / \mathrm{L}$ & many & na & \\
\hline $\mathrm{Fe}(\mathrm{raw})$ & ICP-MS & $50 \mu \mathrm{g} / \mathrm{L}$ & 8 & 13 & $25 \mu \mathrm{g} / \mathrm{L}$ \\
\hline $\mathrm{Gd}$ & ICP-MS & $0.005 \mu \mathrm{g} / \mathrm{L}$ & many & na & \\
\hline Gd (raw) & ICP-MS & $0.005 \mu \mathrm{g} / \mathrm{L}$ & 1 & 2 & $0.003 \mu \mathrm{g} / \mathrm{L}$ \\
\hline Ho & ICP-MS & $0.005 \mu \mathrm{g} / \mathrm{L}$ & many & na & \\
\hline Ho (raw) & ICP-MS & $0.005 \mu \mathrm{g} / \mathrm{L}$ & 11 & 17 & $0.003 \mu \mathrm{g} / \mathrm{L}$ \\
\hline $\mathrm{La}$ & ICP-MS & $0.01 \mu \mathrm{g} / \mathrm{L}$ & many & na & \\
\hline La (raw) & ICP-MS & $0.01 \mu \mathrm{g} / \mathrm{L}$ & 1 & 2 & $0.005 \mu \mathrm{g} / \mathrm{L}$ \\
\hline $\mathrm{Li}$ & ICP-AES & $1 \mu \mathrm{g} / \mathrm{L}$ & 2 & 3 & $0.5 \mu \mathrm{g} / \mathrm{L}$ \\
\hline Mo & ICP-MS & $2 \mu \mathrm{g} / \mathrm{L}$ & many & na & \\
\hline Mo (raw) & ICP-MS & $2 \mu \mathrm{g} / \mathrm{L}$ & many & na & \\
\hline Se (raw) & ICP-MS & $1 \mu \mathrm{g} / \mathrm{L}$ & many & na & \\
\hline $\mathrm{Sm}$ & ICP-MS & $0.01 \mu \mathrm{g} / \mathrm{L}$ & many & na & \\
\hline $\mathrm{Sm}$ (raw) & ICP-MS & $0.01 \mu \mathrm{g} / \mathrm{L}$ & 2 & 3 & $0.005 \mu \mathrm{g} / \mathrm{L}$ \\
\hline $\mathrm{Tb}$ & ICP-MS & $0.005 \mu \mathrm{g} / \mathrm{L}$ & many & na & \\
\hline $\mathrm{Tb}$ (raw) & ICP-MS & $0.005 \mu \mathrm{g} / \mathrm{L}$ & 12 & 19 & $0.003 \mu \mathrm{g} / \mathrm{L}$ \\
\hline $\mathrm{Ti}$ & ICP-MS & $0.5 \mu \mathrm{g} / \mathrm{L}$ & 8 & 13 & $0.3 \mu \mathrm{g} / \mathrm{L}$ \\
\hline $\mathrm{Y}$ & ICP-MS & $0.5 \mu \mathrm{g} / \mathrm{L}$ & many & na & \\
\hline Y (raw) & ICP-MS & $0.5 \mu \mathrm{g} / \mathrm{L}$ & 10 & 16 & $0.3 \mu \mathrm{g} / \mathrm{L}$ \\
\hline $\mathrm{Yb}$ & ICP-MS & $0.005 \mu \mathrm{g} / \mathrm{L}$ & many & na & \\
\hline $\mathrm{Yb}$ (raw) & ICP-MS & $0.005 \mu \mathrm{g} / \mathrm{L}$ & 3 & 5 & $0.003 \mu \mathrm{g} / \mathrm{L}$ \\
\hline $\mathrm{Zn}$ & ICP-AES & $10 \mu \mathrm{g} / \mathrm{L}$ & many & na & \\
\hline
\end{tabular}


Table Al-2. Elements not reported in Appendix 1, because all reported values were less than detection limit, or the few values reported were very near the detection limit. In some instances where the available concentrations did not meet this criteria, concentrations for the few samples were reported.

[ICP-MS, inductive coupled plasma-mass spectrometry; ICP-AES, inductive coupled plasma-atomic emission spectrometry]

\begin{tabular}{llc}
\hline \multicolumn{1}{c}{ Element } & Method & Detection \\
limit
\end{tabular}


Table Al-3. Chemical and isotopic data for all water samples collected in this study.

[Site name is an abbreviation for station name; WS\#, watershed number (see fig. 5 for location); red values are replacement values; na, not analyzed; nr, not reported; CFS, cubic feet per second; IC, ion chromatography; ICP-MS, inductive coupled plasma-mass spectrometry; ICP-AES, inductive coupled plasma-atomic emission spectrometry; (avail.), available loads (operationally defined as total dissolved after acidification of unfiltered sample); ins, insufficient sample; hydrogen and oxygen isotopes reported relative to $\mathrm{V}$-SMOW and sulfur isotope values relative to V-CDT]

\begin{tabular}{|c|c|c|c|c|c|c|c|}
\hline $\begin{array}{c}\text { Station } \\
\text { ID }\end{array}$ & Station name & Site name & WS \# & $\begin{array}{c}\text { Flow } \\
\text { condition }\end{array}$ & N. lat ${ }^{\circ}$ & W. long ${ }^{\circ}$ & Date \\
\hline 09058000 & Colorado River near Kremmling, Colo. & CR-Kremmling & 1 & High water & 40.0367 & -106.4394 & $5 / 24 / 05$ \\
\hline 09058000 & Colorado River near Kremmling, Colo. & CR-Kremmling & 1 & Irrigation & 40.0367 & -106.4394 & $8 / 30 / 05$ \\
\hline 09064600 & Eagle River near Minturn, Colo. & ER-Minturn & 2 & High water & 39.5539 & -106.4019 & $5 / 26 / 05$ \\
\hline 09064600 & Eagle River near Minturn, Colo. & ER-Minturn & 2 & Irrigation & 39.5539 & -106.4019 & $7 / 29 / 05$ \\
\hline 09064600 & Eagle River near Minturn, Colo. & ER-Minturn & 2 & Base flow & 39.5539 & -106.4019 & $10 / 20 / 05$ \\
\hline 09067005 & Eagle River at Avon, Colo. & ER-Avon & 2 & Base flow & 39.6317 & -106.5219 & $10 / 19 / 05$ \\
\hline 09069000 & Eagle River at Gypsum, Colo. & ER-Gypsum & 2 & High water & 39.6500 & -106.9517 & $5 / 24 / 05$ \\
\hline 09069000 & Eagle River at Gypsum, Colo. & ER-Gypsum & 2 & Irrigation & 39.6500 & -106.9517 & $7 / 26 / 05$ \\
\hline 09069000 & Eagle River at Gypsum, Colo. & ER-Gypsum & 2 & Base flow & 39.6500 & -106.9517 & $10 / 20 / 05$ \\
\hline 09071750 & Colorado River above Glenwood Springs, Colo. & CR-Glenwood & 1 & High water & 39.5606 & -107.2997 & $5 / 23 / 05$ \\
\hline 09085000 & Roaring Fork at Glennwood Springs, Colo. & RF-Glenwood & 3 & Base flow & 39.5436 & -107.3289 & $10 / 27 / 05$ \\
\hline 09105000 & Plateau Creek near Cameo, Colo. & PC-Cameo & 8 & High water & 39.1833 & -108.2672 & $6 / 3 / 05$ \\
\hline 09105000 & Plateau Creek near Cameo, Colo. & PC-Cameo & 8 & Irrigation & 39.1833 & -108.2672 & $7 / 14 / 05$ \\
\hline 09105000 & Plateau Creek near Cameo, Colo. & PC-Cameo & 8 & Base flow & 39.1833 & -108.2672 & $10 / 27 / 05$ \\
\hline 09095500 & Colorado River near Cameo, Colo. & CR-Cameo & 8 & High water & 39.2392 & -108.2656 & $6 / 3 / 05$ \\
\hline 09095500 & Colorado River near Cameo, Colo. & CR-Cameo & 8 & Irrigation & 39.2392 & -108.2656 & $7 / 13 / 05$ \\
\hline 09095500 & Colorado River near Cameo, CO Colo. & CR-Cameo & 8 & Base flow & 39.2392 & -108.2656 & $10 / 27 / 05$ \\
\hline 09134100 & North Fork Gunnison River below Paonia, Colo. & GR-NF & 5 & High water & 38.8575 & -107.6219 & $5 / 24 / 05$ \\
\hline 09134100 & North Fork Gunnison River below Paonia, Colo. & GR-NF & 5 & Irrigation & 38.8575 & -107.6219 & $7 / 5 / 05$ \\
\hline 09134100 & North Fork Gunnison River below Paonia, Colo. & GR-NF & 5 & Base flow & 38.8575 & -107.6219 & $11 / 30 / 05$ \\
\hline 09128000 & Gunnison River below Gunnison Tunnel, Colo. & GR-Tunnel & 4 & High water & 38.5292 & -107.6483 & $6 / 24 / 05$ \\
\hline 09146200 & Uncompahgre River near Ridgway, Colo. & UR-Ridgway & 6 & High water & 38.1839 & -107.7453 & $6 / 14 / 05$ \\
\hline 09146200 & Uncompahgre River near Ridgway, Colo. & UR-Ridgway & 6 & Irrigation & 38.1839 & -107.7453 & $8 / 10 / 05$ \\
\hline 09146200 & Uncompahgre River near Ridgway, Colo. & UR-Ridgway & 6 & Base flow & 38.1839 & -107.7453 & $11 / 18 / 05$ \\
\hline 09149500 & Uncompahgre River at Delta, Colo. & UR-Delta & 6 & High water & 38.7419 & -108.0803 & $5 / 27 / 05$ \\
\hline 09149500 & Uncompahgre River at Delta, Colo. & UR-Delta & 6 & Irrigation & 38.7419 & -108.0803 & $8 / 11 / 05$ \\
\hline 09149500 & Uncompahgre River at Delta, Colo. & UR-Delta & 6 & Base flow & 38.7419 & -108.0803 & $11 / 29 / 05$ \\
\hline 09152500 & Gunnison River near Grand Junction, Colo. & GR-Grand Jct. & 7 & High water & 38.9833 & -108.4500 & $6 / 2 / 05$ \\
\hline 09152500 & Gunnison River near Grand Junction, Colo. & GR-Grand Jct. & 7 & Irrigation & 38.9833 & -108.4500 & $7 / 12 / 05$ \\
\hline 09152500 & Gunnison River near Grand Junction, Colo. & GR-Grand Jct. & 7 & Base flow & 38.9833 & -108.4500 & $10 / 31 / 05$ \\
\hline 09163500 & Colorado River near Colorado-Utah State Line & CR-State line & 8 & High water & 39.1328 & -109.0264 & $6 / 1 / 05$ \\
\hline 09163500 & Colorado River near Colorado-Utah State Line & CR-State line & 8 & Irrigation & 39.1328 & -109.0264 & $7 / 11 / 05$ \\
\hline 09163500 & Colorado River near Colorado-Utah State Line & CR-State line & 8 & Base flow & 39.1328 & -109.0264 & $10 / 26 / 05$ \\
\hline 09166500 & Dolores River at Dolores, Colo. & DR-Dolores & 9 & High water & 37.4725 & -108.4969 & $5 / 25 / 05$ \\
\hline 09166500 & Dolores River at Dolores, Colo. & DR-Dolores & 9 & Irrigation & 37.4725 & -108.4969 & $7 / 19 / 05$ \\
\hline 09166500 & Dolores River at Dolores, Colo. & DR-Dolores & 9 & Base flow & 37.4725 & -108.4969 & $10 / 3 / 05$ \\
\hline
\end{tabular}


Table Al-3. Chemical and isotopic data for all water samples collected in this study.-Continued

[Site name is an abbreviation for station name; WS\#, watershed number (see fig. 5 for location); red values are replacement values; na, not analyzed; nr, not reported; CFS, cubic feet per second; IC, ion chromatography; ICP-MS, inductive coupled plasma-mass spectrometry; ICP-AES, inductive coupled plasma-atomic emission spectrometry; (avail.), available loads (operationally defined as total dissolved after acidification of unfiltered sample); ins, insufficient sample; hydrogen and oxygen isotopes reported relative to V-SMOW and sulfur isotope values relative to V-CDT]

\begin{tabular}{|c|c|c|c|c|c|c|c|c|}
\hline $\begin{array}{c}\text { Station } \\
\text { ID }\end{array}$ & \multicolumn{2}{|c|}{ Station name } & Site name & WS \# & $\begin{array}{c}\text { Flow } \\
\text { condition }\end{array}$ & N. lat ${ }^{\circ}$ & W. long ${ }^{\circ}$ & Date \\
\hline 09171100 & \multicolumn{2}{|c|}{ Dolores River near Bedrock, Colo. } & DR-Bedrock & 9 & High water & 38.3569 & -108.8328 & $5 / 31 / 05$ \\
\hline 09171100 & \multicolumn{2}{|c|}{ Dolores River near Bedrock, Colo. } & DR-Bedrock & 9 & Irrigation & 38.3569 & -108.8328 & $7 / 28 / 05$ \\
\hline 09177000 & \multicolumn{2}{|c|}{ San Miguel at Uravan, Colo. } & SM-Uravan & 10 & High water & 38.3572 & -108.7122 & $6 / 1 / 05$ \\
\hline 09177000 & \multicolumn{2}{|c|}{ San Miguel at Uravan, Colo. } & SM-Uravan & 10 & Irrigation & 38.3572 & -108.7122 & $7 / 29 / 05$ \\
\hline 09177000 & \multicolumn{2}{|c|}{ San Miguel at Uravan, Colo. } & SM-Uravan & 10 & Base flow & 38.3572 & -108.7122 & $11 / 15 / 05$ \\
\hline 09180000 & \multicolumn{2}{|c|}{ Dolores River near Cisco, UTUtah } & DR-Cisco & 11 & Irrigation & 38.7972 & -109.1944 & $8 / 5 / 05$ \\
\hline 09180000 & \multicolumn{2}{|c|}{ Dolores River near Cisco, UTUtah } & DR-Cisco & 11 & Base flow & 38.7972 & -109.1944 & $11 / 8 / 05$ \\
\hline 09180500 & Colorado River nea & sco, UTUtah & CR-Cisco & 12 & High water & 38.8106 & -109.2928 & $5 / 21 / 05$ \\
\hline 09180500 & Colorado River nea & sco, UTUtah & CR-Cisco & 12 & Irrigation & 38.8106 & -109.2928 & $7 / 12 / 05$ \\
\hline 09180500 & Colorado River nea & sco, UTUtah & CR-Cisco & 12 & Base flow & 38.8106 & -109.2928 & $11 / 21 / 05$ \\
\hline & Glenwood Springs & spring & GW hot spring & & & 39.55088 & -107.32206 & $8 / 16 / 05$ \\
\hline $\begin{array}{c}\text { Site } \\
\text { name }\end{array}$ & $\begin{array}{c}\text { AA meter } \\
\text { discharge } \\
\text { CFS }\end{array}$ & $\begin{array}{c}\text { Electrode } \\
\text { conductivity } \\
\mu \mathrm{S} / \mathrm{cm} \\
\end{array}$ & $\begin{array}{c}\text { Electrode } \\
\text { pH }\end{array}$ & $\begin{array}{l}\text { Mass spec. } \\
{ }^{18} \mathrm{O}\left(\mathrm{H}_{2} \mathrm{O}\right) \% \%\end{array}$ & $\begin{array}{r}\text { Mass } \\
\delta^{2} \mathrm{H}\end{array}$ & pec. & $\begin{array}{c}\text { tration } \mathrm{HCO}_{3} \\
\mathrm{mg} / \mathrm{L}\end{array}$ & $\begin{array}{c}\text { IC } \\
\mathrm{CI} \mathrm{mg} / \mathrm{L}\end{array}$ \\
\hline CR-Kremmling & 1,230 & 140 & 7.13 & -16.8 & -12 & & 62 & 2.3 \\
\hline CR-Kremmling & 980 & 211 & 8.20 & -16.8 & -12 & & 72 & 5.0 \\
\hline CR-Kremmling & 750 & 200 & 8.20 & -16.8 & -12 & & 78 & 4.5 \\
\hline ER-Minturn & 634 & 103 & 7.42 & -18.4 & -13 & & 45 & 1.7 \\
\hline ER-Minturn & 91 & 140 & 7.61 & -17.1 & -12 & & 70 & 1.7 \\
\hline ER-Minturn & 86 & 110 & 7.60 & -16.3 & -12 & & 52 & 2.3 \\
\hline ER-Avon & 2,180 & 100 & 7.37 & -18.4 & -1 & & 47 & 2.5 \\
\hline RF-Glenwood & 3,520 & 251 & 7.62 & -17.2 & -12 & & 88 & 5.0 \\
\hline RF-Glenwood & 1,340 & 440 & 7.89 & -16.8 & -12 & & 120 & 19 \\
\hline RF-Glenwood & 764 & 600 & 8.40 & -16.4 & -12 & & 140 & 42 \\
\hline PC-Cameo & 1,430 & 195 & 7.70 & -16.0 & -1 & & 26 & 2.0 \\
\hline PC-Cameo & 158 & 520 & 8.21 & -14.8 & -10 & & 22 & 6.4 \\
\hline PC-Cameo & 145 & 590 & 8.30 & -14.5 & -1 & & 35 & 8 \\
\hline CR-Cameo & 10,900 & 397 & 7.64 & -16.9 & -12 & & 83 & 28 \\
\hline CR-Cameo & 5,020 & 527 & 7.91 & -17.0 & -12 & & 105 & 55 \\
\hline CR-Cameo & 2,480 & 920 & 8.20 & -16.2 & -12 & & 115 & 135 \\
\hline GR-NF & 5,190 & 117 & 7.42 & -16.3 & -1 & & 175 & 2.0 \\
\hline GR-NF & 696 & 171 & 7.59 & -16.3 & -1 & & 200 & 2.0 \\
\hline GR-NF & 199 & 310 & 7.90 & -15.1 & -1 & & 250 & 5.2 \\
\hline GR-Tunnel & 744 & 194 & 7.74 & -15.8 & -1 & & 55 & 2.0 \\
\hline GR-Tunnel & 524 & 204 & 7.54 & -15.8 & -1 & & 67 & 2.0 \\
\hline GR-Tunnel & 394 & 200 & 7.80 & -15.9 & -1 & & 175 & 2.4 \\
\hline
\end{tabular}


Table Al-3. Chemical and isotopic data for all water samples collected in this study.-Continued

[Site name is an abbreviation for station name; WS\#, watershed number (see fig. 5 for location); red values are replacement values; na, not analyzed; nr, not reported; CFS, cubic feet per second; IC, ion chromatography; ICP-MS, inductive coupled plasma-mass spectrometry; ICP-AES, inductive coupled plasma-atomic emission spectrometry; (avail.), available loads (operationally defined as total dissolved after acidification of unfiltered sample); ins, insufficient sample; hydrogen and oxygen isotopes reported relative to $\mathrm{V}$-SMOW and sulfur isotope values relative to $\mathrm{V}$-CDT]

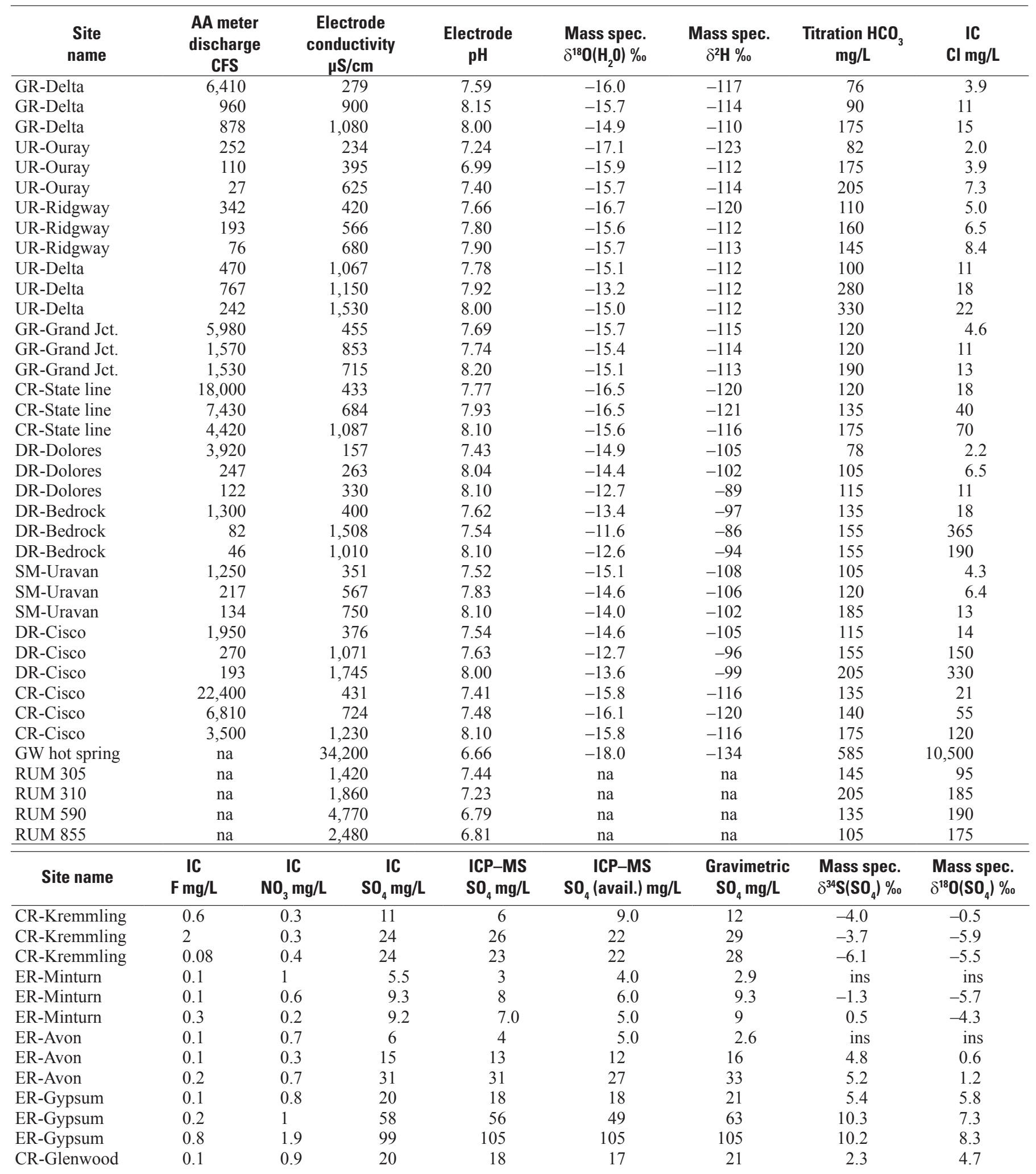


Table Al-3. Chemical and isotopic data for all water samples collected in this study.-Continued

[Site name is an abbreviation for station name; WS\#, watershed number (see fig. 5 for location); red values are replacement values; na, not analyzed; nr, not reported; CFS, cubic feet per second; IC, ion chromatography; ICP-MS, inductive coupled plasma-mass spectrometry; ICP-AES, inductive coupled plasma-atomic emission spectrometry; (avail.), available loads (operationally defined as total dissolved after acidification of unfiltered sample); ins, insufficient sample; hydrogen and oxygen isotopes reported relative to V-SMOW and sulfur isotope values relative to V-CDT]

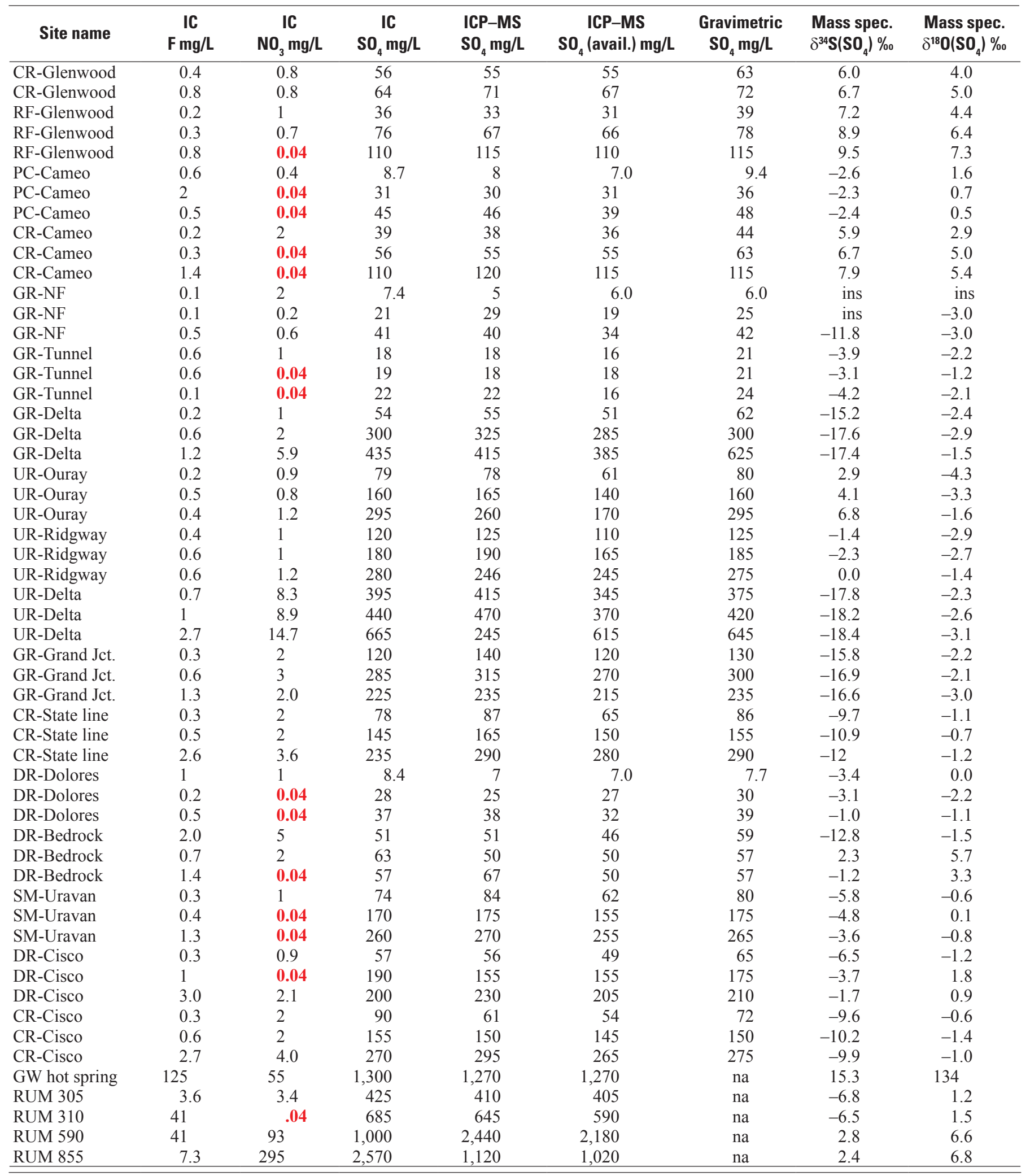


Table Al-3. Chemical and isotopic data for all water samples collected in this study.-Continued

[Site name is an abbreviation for station name; WS\#, watershed number (see fig. 5 for location); red values are replacement values; na, not analyzed; nr, not reported; CFS, cubic feet per second; IC, ion chromatography; ICP-MS, inductive coupled plasma-mass spectrometry; ICP-AES, inductive coupled plasma-atomic emission spectrometry; (avail.), available loads (operationally defined as total dissolved after acidification of unfiltered sample); ins, insufficient sample; hydrogen and oxygen isotopes reported relative to $\mathrm{V}$-SMOW and sulfur isotope values relative to V-CDT]

\begin{tabular}{|c|c|c|c|c|c|c|c|c|c|}
\hline Site name & $\begin{array}{c}\text { ICP-AES } \\
\text { Al } \mu \mathrm{g} / \mathrm{L}\end{array}$ & $\begin{array}{c}\text { ICP-MS } \\
\text { Al } \mu \mathrm{g} / \mathrm{L}\end{array}$ & $\begin{array}{c}\text { ICP-MS } \\
\text { Al (avail.) } \mu \mathrm{g} / \mathrm{L}\end{array}$ & $\begin{array}{c}\text { ICP-AES } \\
\text { B } \mu \mathrm{g} / \mathrm{L}\end{array}$ & $\begin{array}{l}\text { ICP-AES } \\
\text { Ba } \mu g / L\end{array}$ & $\begin{array}{c}\text { ICP-MS } \\
\text { Ва } \mu \mathrm{g} / \mathrm{L}\end{array}$ & $\begin{array}{c}\text { ICP-MS } \\
\text { Ba (avail.) } \mu \mathrm{g} / \mathrm{L}\end{array}$ & $\begin{array}{c}\text { ICP-AES } \\
\text { Ca mg/L }\end{array}$ & $\begin{array}{l}\text { ICP-MS } \\
\text { Ca mg/L }\end{array}$ \\
\hline CR-Kremmling & $<10$ & 12 & 1,450 & $<5$ & 18 & 18 & 69 & 11 & 10 \\
\hline CR-Kremmling & $<10$ & 1.0 & 53 & $<5$ & 36 & 23 & 40 & 26 & 26 \\
\hline ER-Minturn & 33 & 47 & 240 & $<5$ & 37 & 34 & 39 & 13 & 13 \\
\hline ER-Minturn & $<10$ & 19 & 37 & $<5$ & 43 & 42 & 40 & 16 & 16 \\
\hline ER-Minturn & 12 & 16 & 57 & $<5$ & 33 & 32 & 34 & 13 & 12 \\
\hline ER-Avon & $<10$ & 7.3 & 160 & 5.4 & 46 & 47 & 49 & 26 & 24 \\
\hline ER-Gypsum & 22 & 32 & 4,640 & $<5$ & 34 & 32 & 105 & 22 & 22 \\
\hline ER-Gypsum & $<10$ & 9.8 & 145 & $<5$ & 37 & 35 & 42 & 40 & 39 \\
\hline ER-Gypsum & 22 & 3.0 & 130 & 14 & 41 & 41 & 44 & 61 & 58 \\
\hline CR-Glenwood & 14 & 17 & 5,040 & $<5$ & 35 & 32 & 110 & 26 & 25 \\
\hline CR-Glenwood & $<10$ & 8.3 & 870 & $<5$ & 48 & 48 & 58 & 44 & 46 \\
\hline PC-Cameo & $<10$ & 25 & 4,110 & $<5$ & 44 & 42 & 92 & 19 & 20 \\
\hline PC-Cameo & $<10$ & 3.0 & 450 & $<5$ & 110 & 110 & 130 & 48 & 49 \\
\hline PC-Cameo & $<10$ & 1.0 & 430 & 53 & 122 & 115 & 120 & 60 & 52 \\
\hline CR-Cameo & $<10$ & 23 & 2,640 & $<5$ & 44 & 41 & 84 & 38 & 37 \\
\hline CR-Cameo & $<10$ & 4.9 & 420 & $<5$ & 43 & 43 & 54 & 42 & 42 \\
\hline CR-Cameo & $<10$ & 1.0 & 130 & 31 & 51 & 49 & 50 & 71 & 65 \\
\hline GR-NF & 11 & 24 & 9,160 & $<5$ & 33 & 30 & 145 & 15 & 15 \\
\hline GR-NF & 13 & 28 & 125 & $<5$ & 30 & 29 & 34 & 18 & 18 \\
\hline GR-NF & $<10$ & 1.0 & 555 & 37 & 83 & 77 & 85 & 42 & 34 \\
\hline GR-Tunnel & $<10$ & 33 & 165 & $<5$ & 38 & 35 & 40 & 25 & 25 \\
\hline GR-Tunnel & $<10$ & 4.1 & 63 & $<5$ & 35 & 35 & 38 & 25 & 26 \\
\hline GR-Tunnel & $<10$ & 2.8 & 22 & 9.4 & 40 & 37 & 36 & 30 & 26 \\
\hline GR-Delta & $<10$ & 18 & 6,780 & $<5$ & 40 & 37 & 110 & 29 & 30 \\
\hline UR-Delta & $<10$ & 11 & 8,660 & 24 & 58 & 53 & 215 & 130 & 140 \\
\hline UR-Delta & $<10$ & 2.7 & 4,750 & 44 & 54 & 53 & 78 & 145 & 160 \\
\hline UR-Delta & $<10$ & 1.0 & 125 & 175 & 37 & 35 & 36 & 210 & 190 \\
\hline GR-Grand Jct. & $<10$ & 18 & 5,530 & $<5$ & 52 & 50 & 110 & 53 & 53 \\
\hline GR-Grand Jct. & $<10$ & 1.0 & 220 & $<5$ & 46 & 45 & 53 & 96 & 105 \\
\hline GR-Grand Jct. & $<10$ & 5.8 & 88 & 71 & 49 & 49 & 48 & 78 & 76 \\
\hline CR-State line & $<10$ & 14 & 5,070 & $<5$ & 50 & 47 & 110 & 43 & 44 \\
\hline CR-State line & $<10$ & 6.7 & 695 & $<5$ & 50 & 49 & 72 & 64 & 65 \\
\hline CR-State line & 26 & 1.0 & 390 & 82 & 56 & 52 & 55 & 110 & 105 \\
\hline DR-Dolores & 24 & 32 & 6,110 & $<5$ & 66 & 61 & 225 & 21 & 22 \\
\hline DR-Dolores & $<10$ & 9.9 & 47 & $<5$ & 94 & 90 & 105 & 37 & 37 \\
\hline DR-Dolores & 17 & 18 & 39 & 29 & 104 & 105 & 105 & 50 & 46 \\
\hline DR-Bedrock & $<10$ & 11 & 2,460 & $<5$ & 86 & 81 & 170 & 43 & 44 \\
\hline DR-Bedrock & 26 & 26 & 7,930 & $<5$ & 218 & 205 & 510 & 49 & 47 \\
\hline
\end{tabular}


Table Al-3. Chemical and isotopic data for all water samples collected in this study.-Continued

[Site name is an abbreviation for station name; WS\#, watershed number (see fig. 5 for location); red values are replacement values; na, not analyzed; nr, not reported; CFS, cubic feet per second; IC, ion chromatography; ICP-MS, inductive coupled plasma-mass spectrometry; ICP-AES, inductive coupled plasma-atomic emission spectrometry; (avail.), available loads (operationally defined as total dissolved after acidification of unfiltered sample); ins, insufficient sample; hydrogen and oxygen isotopes reported relative to $\mathrm{V}$-SMOW and sulfur isotope values relative to $\mathrm{V}$-CDT]

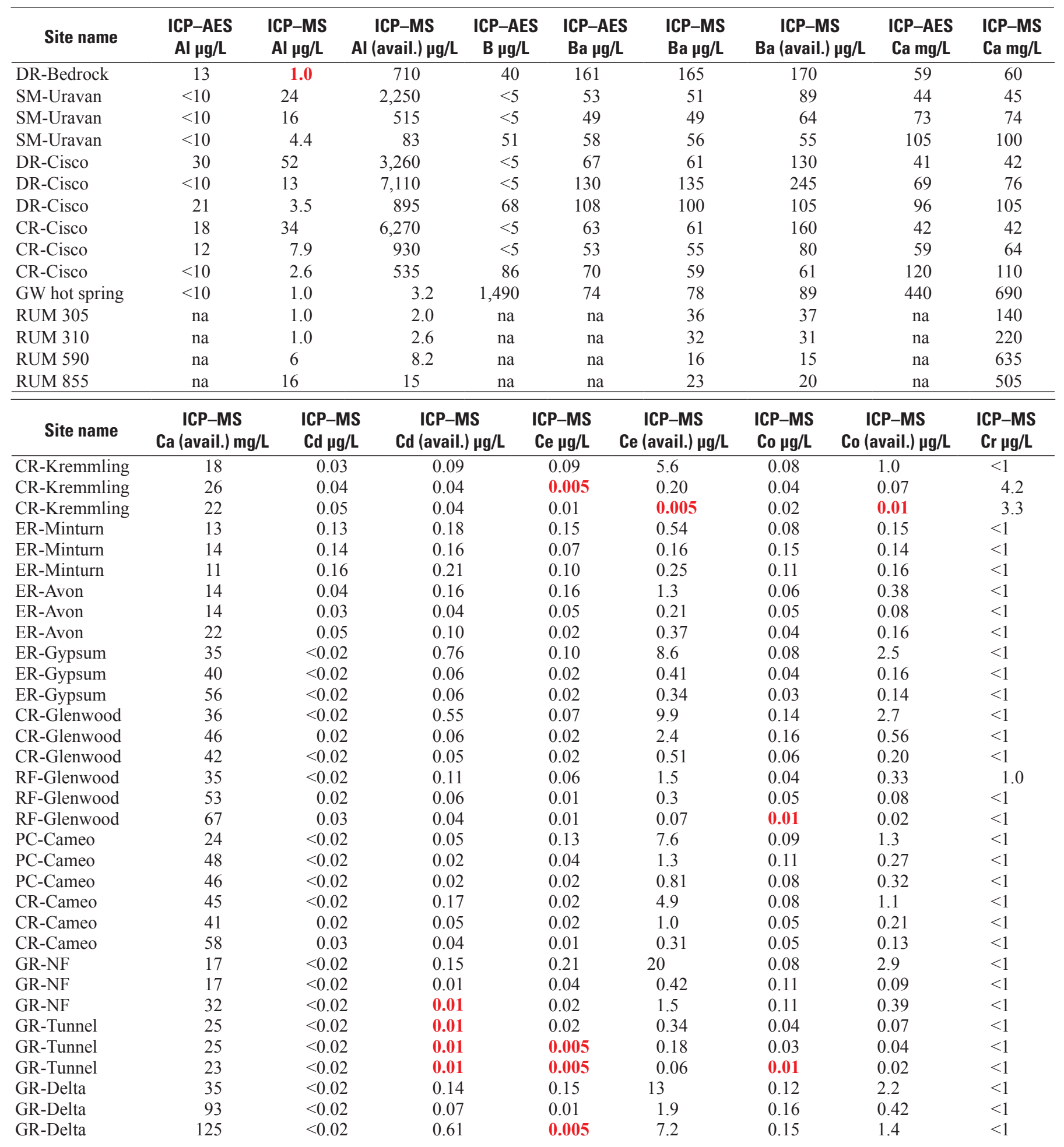


Table Al-3. Chemical and isotopic data for all water samples collected in this study.-Continued

[Site name is an abbreviation for station name; WS\#, watershed number (see fig. 5 for location); red values are replacement values; na, not analyzed; nr, not reported; CFS, cubic feet per second; IC, ion chromatography; ICP-MS, inductive coupled plasma-mass spectrometry; ICP-AES, inductive coupled plasma-atomic emission spectrometry; (avail.), available loads (operationally defined as total dissolved after acidification of unfiltered sample); ins, insufficient sample; hydrogen and oxygen isotopes reported relative to $\mathrm{V}$-SMOW and sulfur isotope values relative to $\mathrm{V}-\mathrm{CDT}$ ]

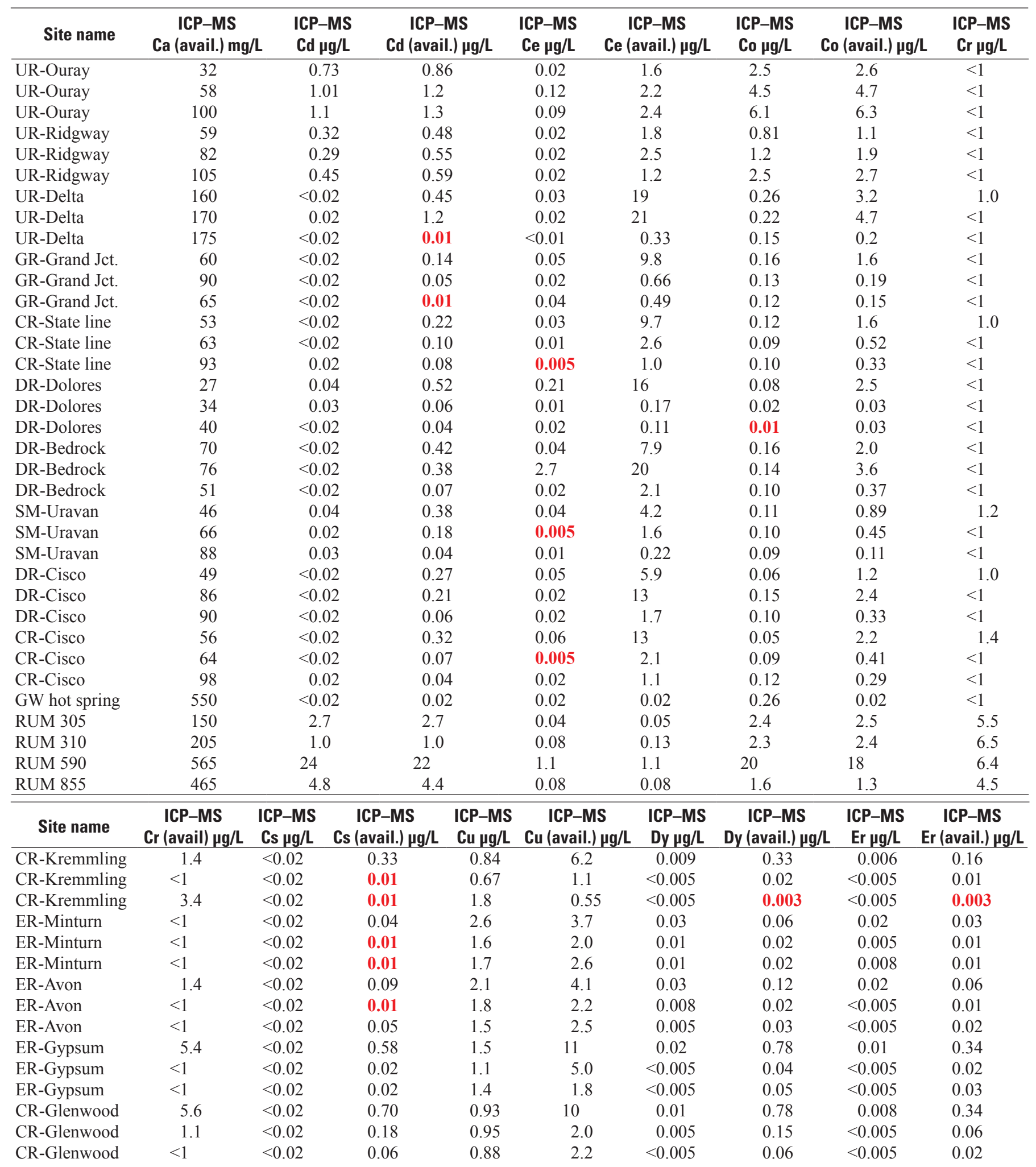


Table Al-3. Chemical and isotopic data for all water samples collected in this study.-Continued

[Site name is an abbreviation for station name; WS\#, watershed number (see fig. 5 for location); red values are replacement values; na, not analyzed; nr, not reported; CFS, cubic feet per second; IC, ion chromatography; ICP-MS, inductive coupled plasma-mass spectrometry; ICP-AES, inductive coupled plasma-atomic emission spectrometry; (avail.), available loads (operationally defined as total dissolved after acidification of unfiltered sample); ins, insufficient sample; hydrogen and oxygen isotopes reported relative to $\mathrm{V}$-SMOW and sulfur isotope values relative to V-CDT]

\begin{tabular}{|c|c|c|c|c|c|c|c|c|c|}
\hline Site name & $\begin{array}{c}\text { ICP-MS } \\
\text { Cr (avail) } \mu \mathrm{g} / \mathrm{L}\end{array}$ & $\begin{array}{c}\text { ICP-MS } \\
\text { Cs } \mu g / L\end{array}$ & $\begin{array}{c}\text { ICP-MS } \\
\text { Cs (avail.) } \mu \mathrm{g} / \mathrm{L}\end{array}$ & $\begin{array}{c}\text { ICP-MS } \\
\text { Cu } \mu g / L\end{array}$ & $\begin{array}{c}\text { ICP-MS } \\
\text { Cu (avail.) } \mu \mathrm{g} / \mathrm{L}\end{array}$ & $\begin{array}{c}\text { ICP-MS } \\
\text { Dy } \mu g / L\end{array}$ & $\begin{array}{c}\text { ICP-MS } \\
\text { Dy (avail.) } \mu \mathrm{g} / \mathrm{L}\end{array}$ & $\begin{array}{c}\text { ICP-MS } \\
\text { Er } \mu g / L\end{array}$ & $\begin{array}{c}\text { ICP-MS } \\
\text { Er (avail.) } \mu \mathrm{g} / \mathrm{L}\end{array}$ \\
\hline RF-Glenwood & $<1$ & $<0.02$ & 0.10 & 0.88 & 1.8 & 0.02 & 0.15 & 0.009 & 0.07 \\
\hline RF-Glenwood & $<1$ & $<0.02$ & 0.06 & 0.66 & 0.95 & $<0.005$ & 0.03 & $<0.005$ & 0.01 \\
\hline PC-Cameo & 3.1 & $<0.02$ & 0.23 & 1.0 & 4.2 & 0.03 & 0.47 & 0.02 & 0.23 \\
\hline PC-Cameo & $<1$ & $<0.02$ & 0.04 & 1.4 & 1.9 & 0.007 & 0.07 & $<0.005$ & 0.04 \\
\hline PC-Cameo & $<1$ & $<0.02$ & 0.02 & 1.0 & 1.6 & $<0.005$ & 0 & $<0.005$ & 0.051 \\
\hline CR-Cameo & $<1$ & 0.10 & 0.15 & 0.94 & 1.1 & $<0.005$ & 0.04 & $<0.005$ & 0.02 \\
\hline GR-NF & 5.3 & $<0.02$ & 0.66 & 1.1 & 8.8 & 0.04 & 1.2 & 0.02 & 0.58 \\
\hline GR-NF & $<1$ & $<0.02$ & 0.01 & 0.93 & 0.76 & 0.01 & 0.04 & 0.009 & 0.03 \\
\hline GR-NF & $<1$ & $<0.02$ & 0.07 & 0.69 & 1.4 & 0.005 & 0.13 & $<0.005$ & 0.05 \\
\hline GR-Tunnel & $<1$ & $<0.02$ & 0.02 & 0.84 & 1.2 & 0.005 & 0.03 & $<0.005$ & 0.01 \\
\hline GR-Tunnel & $<1$ & $<0.02$ & 0.01 & 1.2 & 1.8 & $<0.005$ & 0.02 & $<0.005$ & 0.01 \\
\hline GR-Delta & 1.9 & $<0.02$ & 0.08 & 2.4 & 4.6 & $<0.005$ & 0.83 & $<0.005$ & 0.35 \\
\hline UR-Ouray & $<1$ & 0.40 & 0.50 & 5.2 & 66 & $<0.005$ & 0.15 & $<0.005$ & 0.06 \\
\hline UR-Ouray & $<1$ & 0.78 & 0.96 & 6.4 & 105 & 0.006 & 0.22 & $<0.005$ & 0.10 \\
\hline UR-Ouray & $<1$ & 2.7 & 2.7 & 9.0 & 135 & 0.005 & 0.25 & $<0.005$ & 0.11 \\
\hline UR-Ridgway & $<1$ & 0.18 & 0.40 & 6.0 & 27 & $<0.005$ & 0.13 & $<0.005$ & 0.05 \\
\hline UR-Ridgway & $<1$ & 0.18 & 0.46 & 4.6 & 42 & $<0.005$ & 0.23 & $<0.005$ & 0.10 \\
\hline UR-Ridgway & $<1$ & 0.99 & 1.05 & 5.4 & 58 & $<0.005$ & 0.13 & $<0.005$ & 0.05 \\
\hline UR-Delta & 5.9 & $<0.02$ & 1.1 & 2.4 & 15 & 0.01 & 1.2 & $<0.005$ & 0.54 \\
\hline UR-Delta & 5.5 & $<0.02$ & 0.26 & 2.3 & 15 & 0.006 & 2.1 & $<0.005$ & 0.90 \\
\hline UR-Delta & $<1$ & $<0.02$ & 0.03 & 2.7 & 3.1 & $<0.005$ & 0.03 & $<0.005$ & 0.01 \\
\hline GR-Grand Jct. & 3.8 & $<0.02$ & 0.52 & 1.5 & 6.0 & 0.01 & 0.67 & 0.01 & 0.30 \\
\hline GR-Grand Jct. & $<1$ & $<0.02$ & 0.05 & 1.9 & 2.4 & 0.005 & 0.06 & $<0.005$ & 0.02 \\
\hline DR-Bedrock & 4.0 & $<0.02$ & 0.13 & 2.7 & 16 & 0.15 & 2.0 & 0.04 & 0.83 \\
\hline DR-Bedrock & $<1$ & $<0.02$ & 0.07 & 1.1 & 2.1 & $<0.005$ & 0.15 & $<0.005$ & 0.07 \\
\hline SM-Uravan & 1.7 & $<0.02$ & 0.39 & 2.4 & 9.3 & 0.01 & 0.29 & 0.007 & 0.13 \\
\hline SM-Uravan & $<1$ & $<0.02$ & 0.08 & 1.6 & 3.3 & $<0.005$ & 0.11 & $<0.005$ & 0.06 \\
\hline SM-Uravan & $<1$ & $<0.02$ & 0.01 & 1.8 & 2.0 & $<0.005$ & 0.02 & $<0.005$ & 0.01 \\
\hline DR-Cisco & 2.3 & $<0.02$ & 0.36 & 2.3 & 7.5 & 0.008 & 0.45 & $<0.005$ & 0.20 \\
\hline DR-Cisco & 4.8 & $<0.02$ & 0.84 & 1.9 & 8.6 & 0.006 & 0.81 & $<0.005$ & 0.37 \\
\hline DR-Cisco & 1.1 & $<0.02$ & 0.13 & 1.5 & 2.4 & $<0.005$ & 0.12 & $<0.005$ & 0.05 \\
\hline CR-Cisco & 5.2 & $<0.02$ & 0.66 & 4.3 & 14 & 0.005 & 0.89 & $<0.005$ & 0.39 \\
\hline CR-Cisco & 1.3 & $<0.02$ & 0.19 & 1.4 & 3.0 & $<0.005$ & 0.14 & $<0.005$ & 0.06 \\
\hline CR-Cisco & $<1$ & $<0.02$ & 0.09 & 1.7 & 3.0 & 0.005 & 0.08 & $<0.005$ & 0.03 \\
\hline GW hot spring & 1.0 & 59 & 73 & 4.1 & 7.6 & 0.006 & 0.005 & $<0.005$ & 0.006 \\
\hline RUM 305 & 4.2 & 0.28 & 0.29 & 7.0 & 8.0 & 0.01 & 0.009 & 0.006 & 0.007 \\
\hline RUM 310 & 5.9 & 0.70 & 0.68 & 3.2 & 3.4 & 0.02 & 0.02 & 0.02 & 0.02 \\
\hline RUM 590 & 5.8 & 10 & 9.5 & 18 & 17 & 0.20 & 0.21 & 0.13 & 0.13 \\
\hline RUM 855 & 4.9 & 0.17 & 0.16 & 7.0 & 7.1 & 0.03 & 0.02 & 0.02 & 0.02 \\
\hline
\end{tabular}


Table Al-3. Chemical and isotopic data for all water samples collected in this study._-Continued

[Site name is an abbreviation for station name; WS\#, watershed number (see fig. 5 for location); red values are replacement values; na, not analyzed; nr, not reported; CFS, cubic feet per second; IC, ion chromatography; ICP-MS, inductive coupled plasma-mass spectrometry; ICP-AES, inductive coupled plasma-atomic emission spectrometry; (avail.), available loads (operationally defined as total dissolved after acidification of unfiltered sample); ins, insufficient sample; hydrogen and oxygen isotopes reported relative to $\mathrm{V}$-SMOW and sulfur isotope values relative to V-CDT]

\begin{tabular}{|c|c|c|c|c|c|c|c|c|c|c|}
\hline Site name & $\begin{array}{l}\text { ICP-MS } \\
\text { Eu } \mu \mathrm{g} / \mathrm{L}\end{array}$ & $\begin{array}{c}\text { ICP-MS } \\
\text { Eu (avail.) } \mu \mathrm{g} / \mathrm{L}\end{array}$ & $\begin{array}{c}\text { ICP-MS } \\
\text { Fe } \mu g / L\end{array}$ & $\begin{array}{c}\text { ICP-MS } \\
\text { Fe (avail.) } \mu \mathrm{g} / \mathrm{L}\end{array}$ & $\begin{array}{c}\text { ICP-MS } \\
\text { Gd } \mu \mathrm{g} / \mathrm{L}\end{array}$ & $\begin{array}{c}\text { ICP-MS } \\
\text { Gd (avail.) } \mu \mathrm{g} / \mathrm{L}\end{array}$ & $\begin{array}{l}\text { ICP-MS } \\
\text { Ho } \mu \mathrm{g} / \mathrm{L}\end{array}$ & $\begin{array}{c}\text { ICP-MS } \\
\text { Ho (avail.) } \mu \mathrm{g} / \mathrm{L}\end{array}$ & $\begin{array}{c}\text { ICP-AES } \\
\mathrm{K} \mathrm{mg/L}\end{array}$ & $\begin{array}{c}\text { ICP-MS } \\
\mathrm{K} \mathrm{mg/L}\end{array}$ \\
\hline CR-Kremmling & 0.006 & 0.11 & 51 & 2,700 & 0.009 & 0.46 & $<0.005$ & 0.05 & 1.0 & 0.90 \\
\hline CR-Kremmling & 0.003 & 0.01 & $<50$ & 140 & $<0.005$ & 0.02 & $<0.005$ & 0.003 & 1.6 & 1.6 \\
\hline ER-Minturn & 0.01 & 0.02 & $<50$ & 345 & 0.04 & 0.08 & 0.005 & 0.01 & 0.72 & 0.64 \\
\hline ER-Minturn & 0.01 & 0.01 & 310 & 485 & 0.02 & 0.02 & $<0.005$ & 0.003 & 0.59 & 0.6 \\
\hline ER-Minturn & 0.006 & 0.01 & 222 & 555 & 0.01 & 0.03 & $<0.005$ & 0.005 & 0.80 & 0.73 \\
\hline ER-Avon & 0.006 & 0.02 & $<50$ & 325 & 0.007 & 0.05 & $<0.005$ & 0.006 & 0.96 & 0.88 \\
\hline ER-Gypsum & 0.01 & 0.27 & $<50$ & 6,170 & 0.03 & 1.2 & 0.005 & 0.12 & 0.88 & 0.79 \\
\hline ER-Gypsum & 0.006 & 0.02 & $<50$ & 230 & $<0.005$ & 0.06 & $<0.005$ & 0.007 & 1.3 & 1.2 \\
\hline ER-Gypsum & 0.007 & 0.02 & $<50$ & 245 & 0.005 & 0.08 & $<0.005$ & 0.008 & 2.0 & 1.9 \\
\hline CR-Glenwood & 0.01 & 0.27 & $<50$ & 6,600 & 0.02 & 1.2 & $<0.005$ & 0.13 & 1.1 & 1.1 \\
\hline RF-Glenwood & 0.007 & 0.01 & $<50$ & 25 & $<0.005$ & 0.01 & $<0.005$ & 0.003 & 1.7 & 1.5 \\
\hline PC-Cameo & 0.02 & 0.16 & $<50$ & 2,900 & 0.04 & 0.71 & 0.005 & 0.08 & 1.4 & 1.3 \\
\hline PC-Cameo & 0.02 & 0.04 & $<50$ & 390 & 0.01 & 0.12 & $<0.005$ & 0.02 & 3.7 & 3.8 \\
\hline PC-Cameo & 0.02 & 0.05 & $<50$ & 315 & 0.005 & 0.15 & $<0.005$ & 0.02 & 4.1 & 3.7 \\
\hline CR-Cameo & 0.009 & 0.14 & $<50$ & 2,280 & 0.008 & 0.6 & $<0.005$ & 0.06 & 1.3 & 1.4 \\
\hline CR-Cameo & 0.006 & 0.03 & $<50$ & 410 & 0.005 & 0.13 & $<0.005$ & 0.01 & 1.7 & 1.7 \\
\hline CR-Cameo & 0.008 & 0.02 & $<50$ & 125 & 0.005 & 0.06 & $<0.005$ & 0.007 & 3.1 & 2.9 \\
\hline GR-NF & 0.02 & 0.44 & $<50$ & 8,290 & 0.04 & 1.9 & 0.007 & 0.20 & 0.9 & 0.91 \\
\hline GR-NF & 0.008 & 0.02 & $<50$ & 105 & 0.01 & 0.06 & $<0.005$ & 0.008 & 4.6 & 4.7 \\
\hline GR-NF & 0.01 & 0.05 & $<50$ & 660 & $<0.005$ & 0.20 & $<0.005$ & 0.02 & 1.1 & 0.99 \\
\hline GR-Tunnel & 0.006 & 0.01 & $<50$ & 110 & 0.008 & 0.04 & $<0.005$ & 0.003 & 1.6 & 1.6 \\
\hline GR-Tunnel & 0.005 & 0.01 & $<50$ & 25 & $<0.005$ & 0.02 & $<0.005$ & 0.003 & 1.4 & 1.4 \\
\hline UR-Ridgway & 0.006 & 0.05 & $<50$ & 925 & $<0.005$ & 0.20 & $<0.005$ & 0.02 & 1.3 & 1.3 \\
\hline UR-Ridgway & 0.007 & 0.08 & $<50$ & 1,690 & 0.005 & 0.34 & $<0.005$ & 0.04 & 1.6 & 1.7 \\
\hline UR-Ridgway & 0.005 & 0.04 & $<50$ & 1,250 & $<0.005$ & 0.18 & $<0.005$ & 0.02 & 2.0 & 1.8 \\
\hline UR-Delta & 0.01 & 0.44 & $<50$ & 7,780 & 0.007 & 1.9 & $<0.005$ & 0.20 & 3.2 & 3.4 \\
\hline UR-Delta & 0.009 & 0.59 & $<50$ & 7,450 & $<0.005$ & 2.89 & $<0.005$ & 0.35 & 4.5 & 4.8 \\
\hline UR-Delta & 0.005 & 0.01 & $<50$ & 145 & $<0.005$ & 0.04 & $<0.005$ & 0.006 & 4.0 & 3.5 \\
\hline GR-Grand Jct. & 0.01 & 0.23 & $<50$ & 4,410 & 0.02 & 1.1 & $<0.005$ & 0.11 & 2.0 & 2.1 \\
\hline GR-Grand Jct. & 0.007 & 0.02 & $<50$ & 175 & 0.006 & 0.07 & $<0.005$ & 0.01 & 2.8 & 3.1 \\
\hline GR-Grand Jct. & 0.009 & 0.02 & $<50$ & 125 & 0.02 & 0.10 & $<0.005$ & 0.007 & 3.3 & 3.3 \\
\hline CR-State line & 0.009 & 0.22 & $<50$ & 4,370 & 0.01 & 0.99 & $<0.005$ & 0.1 & 1.6 & 1.7 \\
\hline CR-State line & 0.007 & 0.07 & $<50$ & 870 & 0.005 & 0.32 & $<0.005$ & 0.04 & 2.2 & 2.3 \\
\hline CR-State line & 0.007 & 0.04 & $<50$ & 405 & $<0.005$ & 0.17 & $<0.005$ & 0.02 & 3.8 & 3.4 \\
\hline DR-Dolores & 0.02 & 0.39 & $<50$ & 5,140 & 0.066 & 1.7 & 0.008 & 0.18 & 0.94 & 0.92 \\
\hline DR-Dolores & 0.01 & 0.02 & $<50$ & 25 & $<0.005$ & 0.03 & $<0.005$ & 0.003 & 1.4 & 1.3 \\
\hline DR-Dolores & 0.02 & 0.02 & $<50$ & 25 & $<0.005$ & 0.02 & $<0.005$ & 0.003 & 1.9 & 1.9 \\
\hline
\end{tabular}


Table Al-3. Chemical and isotopic data for all water samples collected in this study.-Continued

[Site name is an abbreviation for station name; WS\#, watershed number (see fig. 5 for location); red values are replacement values; na, not analyzed; nr, not reported; CFS, cubic feet per second; IC, ion chromatography; ICP-MS, inductive coupled plasma-mass spectrometry; ICP-AES, inductive coupled plasma-atomic emission spectrometry; (avail.), available loads (operationally defined as total dissolved after acidification of unfiltered sample); ins, insufficient sample; hydrogen and oxygen isotopes reported relative to $\mathrm{V}$-SMOW and sulfur isotope values relative to V-CDT]

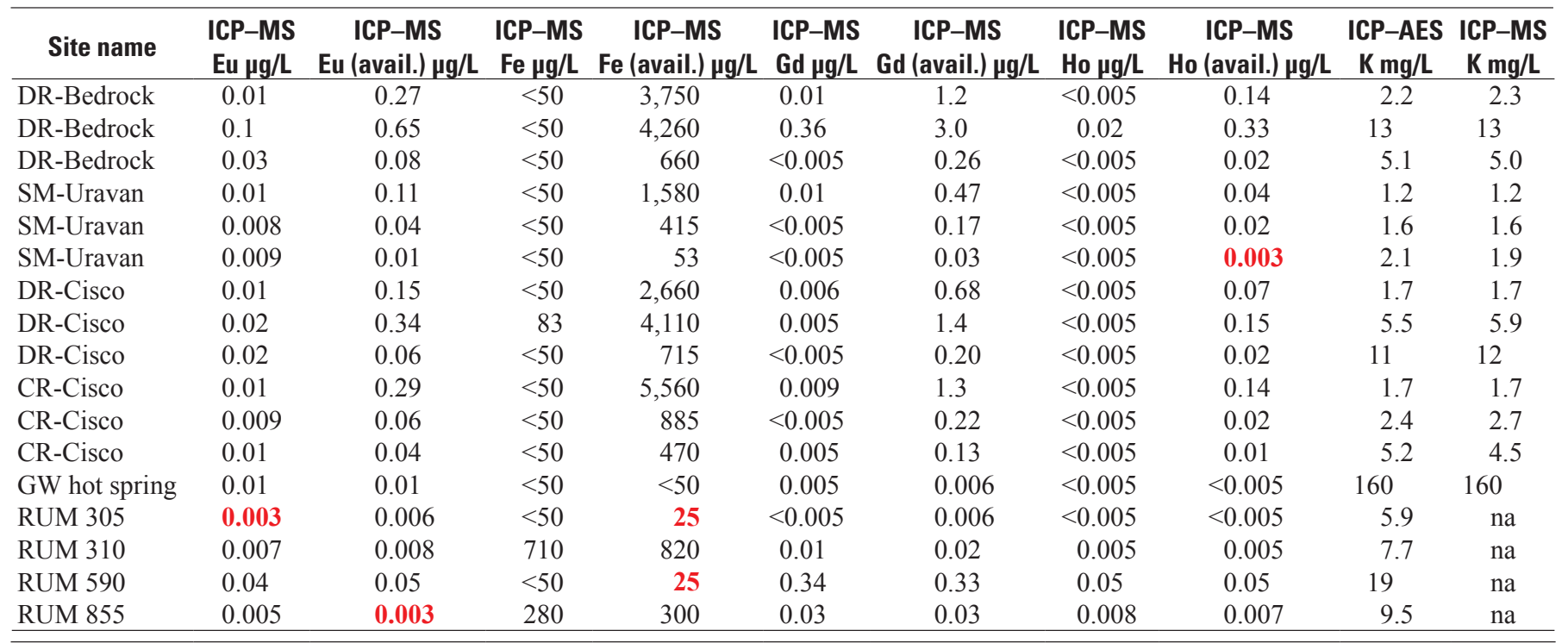

\begin{tabular}{|c|c|c|c|c|c|c|c|c|c|c|}
\hline Site name & $\begin{array}{c}\text { ICP-MS } \\
\text { K (avail.) mg/L }\end{array}$ & $\begin{array}{c}\text { ICP-MS } \\
\mathrm{La} \mu \mathrm{g} / \mathrm{L}\end{array}$ & $\begin{array}{c}\text { ICP-MS } \\
\text { La (avail.) } \mu \mathrm{g} / \mathrm{L}\end{array}$ & $\begin{array}{c}\text { ICP-AES } \\
\text { Li } \mu g / L\end{array}$ & $\begin{array}{c}\text { ICP-MS } \\
\text { Li } \mu g / L\end{array}$ & $\begin{array}{c}\text { ICP-MS } \\
\text { Li (avail.) } \mu \mathrm{g} / \mathrm{L}\end{array}$ & $\begin{array}{l}\text { ICP-AES } \\
\text { Mg mg/L }\end{array}$ & $\begin{array}{l}\text { ICP-MS } \\
\text { Mg mg/L }\end{array}$ & $\begin{array}{c}\text { ICP-MS } \\
\text { Mg (avail.) mg/L }\end{array}$ & $\begin{array}{l}\text { ICP-AES } \\
\text { Mn } \mu g / L\end{array}$ \\
\hline CR-Kremmling & 1.6 & $<0.01$ & 0.11 & 6.2 & 5.6 & 6.3 & 4.7 & 4.6 & 4.3 & $<10$ \\
\hline ER-Minturn & 0.66 & 0.10 & 0.27 & 1.0 & 1.3 & 1.4 & 4.7 & 4.5 & 3.9 & 28 \\
\hline ER-Minturn & 0.55 & 0.04 & 0.09 & 1.2 & 1.0 & 1.8 & 5.6 & 5.7 & 4.8 & 99 \\
\hline ER-Minturn & 0.76 & 0.05 & 0.13 & 0.5 & 1.0 & 1.5 & 4.9 & 4.8 & 4.5 & 90 \\
\hline ER-Avon & 0.89 & 0.01 & 0.20 & 5.2 & 3.9 & 5.2 & 7.3 & 7.3 & 6.8 & 44 \\
\hline ER-Gypsum & 1.9 & 0.08 & 3.9 & 1.4 & 2.2 & 7.6 & 4.4 & 4.2 & 6.3 & 13 \\
\hline ER-Gypsum & 1.2 & 0.02 & 0.20 & 3.6 & 3.2 & 4.2 & 7.3 & 7.2 & 7.0 & 10 \\
\hline ER-Gypsum & 1.9 & $<0.01$ & 0.15 & 3.8 & 2.6 & 5.4 & 12 & 11 & 11 & $<10$ \\
\hline CR-Glenwood & 2.4 & 0.04 & 4.5 & 3.4 & 3.7 & 9.3 & 5.4 & 5.3 & 7.3 & 43 \\
\hline CR-Glenwood & 2.2 & 0.01 & 0.98 & 6.8 & 7.2 & 9.4 & 8.2 & 8.7 & 8.7 & 13 \\
\hline PC-Cameo & 2.1 & 0.08 & 3.2 & 3.0 & 3.8 & 6.9 & 6.3 & 6.6 & 7.7 & $<10$ \\
\hline PC-Cameo & 3.8 & 0.02 & 0.52 & 13 & 12 & 17 & 23 & 24 & 23 & $<10$ \\
\hline PC-Cameo & 3.7 & 0.01 & 0.33 & 16 & 15 & 18 & 32 & 30 & 27 & $<10$ \\
\hline CR-Cameo & 2.1 & 0.02 & 2.1 & 6.8 & 6.4 & 9.7 & 8.8 & 9.0 & 11 & $<10$ \\
\hline CR-Cameo & 1.7 & 0.01 & 0.46 & 7.6 & 8.9 & 12 & 8.6 & 9.1 & 8.8 & $<10$ \\
\hline CR-Cameo & 2.8 & $<0.01$ & 0.13 & 17 & 17 & 20 & 17 & 15 & 14 & $<10$ \\
\hline GR-NF & 2.7 & 0.13 & 8.7 & 0.5 & 1.5 & 7.2 & 2.7 & 2.7 & 4.3 & 12 \\
\hline GR-NF & 0.61 & 0.03 & 0 & 12 & 12 & 3.4 & 5.0 & 5.0 & 4.6 & 11 \\
\hline GR-NF & 1.1 & 0.01 & 0.61 & 5.8 & 4.1 & 6.3 & 11 & 11 & 10 & 39 \\
\hline GR-Tunnel & 1.6 & 0.02 & 0.15 & 4.3 & 4.8 & 4.9 & 5.5 & 5.5 & 4.9 & $<10$ \\
\hline GR-Tunnel & 1.4 & $<0.01$ & 0.09 & 3.7 & 4.7 & 6.0 & 5.2 & 5.3 & 5.1 & $<10$ \\
\hline GR-Tunnel & 1.3 & $<0.01$ & 0.03 & 5.5 & 5.1 & 6.2 & 6.3 & 6.0 & 5.1 & $<10$ \\
\hline
\end{tabular}


Table Al-3. Chemical and isotopic data for all water samples collected in this study.-Continued

[Site name is an abbreviation for station name; WS\#, watershed number (see fig. 5 for location); red values are replacement values; na, not analyzed; nr, not reported; CFS, cubic feet per second; IC, ion chromatography; ICP-MS, inductive coupled plasma-mass spectrometry; ICP-AES, inductive coupled plasma-atomic emission spectrometry; (avail.), available loads (operationally defined as total dissolved after acidification of unfiltered sample); ins, insufficient sample; hydrogen and oxygen isotopes reported relative to $\mathrm{V}$-SMOW and sulfur isotope values relative to $\mathrm{V}-\mathrm{CDT}$ ]

\begin{tabular}{|c|c|c|c|c|c|c|c|c|c|c|}
\hline Site name & $\begin{array}{c}\text { ICP-MS } \\
\text { K (avail.) mg/L }\end{array}$ & $\begin{array}{l}\text { ICP-MS } \\
\text { La } \mu g / L\end{array}$ & $\begin{array}{c}\text { ICP-MS } \\
\text { La (avail.) } \mu \mathrm{g} / \mathrm{L}\end{array}$ & $\begin{array}{c}\text { ICP-AES } \\
\mathrm{Li} \mu \mathrm{g} / \mathrm{L}\end{array}$ & $\begin{array}{c}\text { ICP-MS } \\
\text { Li } \mu g / L\end{array}$ & $\begin{array}{c}\text { ICP-MS } \\
\text { Li (avail.) } \mu \mathrm{g} / \mathrm{L}\end{array}$ & $\begin{array}{l}\text { ICP-AES } \\
\text { Mg mg/L }\end{array}$ & $\begin{array}{l}\text { ICP-MS } \\
\text { Mg mg/L }\end{array}$ & $\begin{array}{c}\text { ICP-MS } \\
\text { Mg (avail.) mg/L }\end{array}$ & $\begin{array}{l}\text { ICP-AES } \\
\mathrm{Mn} \mu \mathrm{g} / \mathrm{L}\end{array}$ \\
\hline UR-Ouray & 0.56 & 0.02 & 0.79 & 12 & 13 & 12 & 2.2 & 2.2 & 1.8 & 213 \\
\hline UR-Ouray & 0.81 & 0.12 & 1.0 & 28 & 30 & 29 & 3.2 & 3.2 & 2.9 & 307 \\
\hline UR-Ridgway & 1.3 & 0.01 & 0.88 & 28 & 29 & 29 & 6.3 & 6.2 & 5.2 & 94 \\
\hline UR-Ridgway & 1.6 & 0.02 & 1.1 & 42 & 43 & 44 & 9.2 & 9.6 & 8.3 & 130 \\
\hline UR-Ridgway & 1.8 & 0.02 & 0.56 & 67 & 59 & 71 & 11 & 10 & 9.9 & 185 \\
\hline UR-Delta & 5.1 & $<0.01$ & 8.5 & 65 & 63 & 74 & 35 & 37 & 31 & 23 \\
\hline UR-Delta & 3.4 & $<0.01$ & 0.14 & 120 & 92 & 110 & 63 & 48 & 48 & 50 \\
\hline GR-Grand Jct. & 3.3 & 0.03 & 4.1 & 20 & 21 & 26 & 14 & 15 & 17 & 16 \\
\hline GR-Grand Jct. & 2.9 & $<0.01$ & 0.29 & 42 & 43 & 51 & 27 & 29 & 25 & $<10$ \\
\hline GR-Grand Jct. & 3.1 & 0.02 & 0.17 & 31 & 31 & 35 & 30 & 29 & 26 & 38 \\
\hline CR-State line & 2.9 & 0.02 & 4.2 & 11 & 13 & 17 & 11 & 12 & 14 & $<10$ \\
\hline DR-Dolores & 1.8 & 0.01 & 0.06 & 22 & 24 & 27 & 7.4 & 7.7 & 6.9 & $<10$ \\
\hline DR-Bedrock & 3.0 & 0.02 & 3.1 & 14 & 16 & 20 & 9.0 & 9.4 & 13 & $<10$ \\
\hline DR-Bedrock & 14 & 1.47 & 9.2 & 17 & 17 & 33 & 13 & 13 & 18 & 11 \\
\hline DR-Bedrock & 4.9 & 0.01 & 0.92 & 30 & 32 & 35 & 16 & 17 & 15 & 10 \\
\hline SM-Uravan & 1.7 & 0.03 & 1.9 & 9.8 & 11 & 12 & 9.6 & 10 & 10 & 21 \\
\hline SM-Uravan & 1.5 & $<0.01$ & 0.72 & 21 & 23 & 27 & 18 & 18 & 16 & 11 \\
\hline SM-Uravan & 1.8 & $<0.01$ & 0.1 & 34 & 33 & 37 & 33 & 31 & 28 & 24 \\
\hline DR-Cisco & 2.7 & 0.02 & 2.6 & 11 & 12 & 14 & 8.6 & 8.7 & 10 & $<10$ \\
\hline DR-Cisco & 8.8 & 0.01 & 5.9 & 22 & 23 & 39 & 19 & 20 & 23 & $<10$ \\
\hline DR-Cisco & 11 & 0.01 & 0.72 & 30 & 27 & 31 & 31 & 34 & 29 & $<10$ \\
\hline CR-Cisco & 3.4 & 0.04 & 5.5 & 10 & 11 & 17 & 10 & 10 & 13 & $<10$ \\
\hline
\end{tabular}

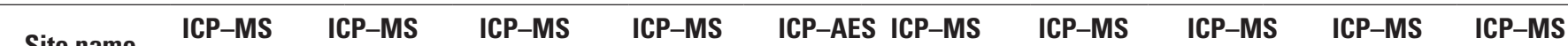

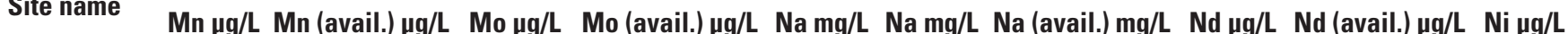

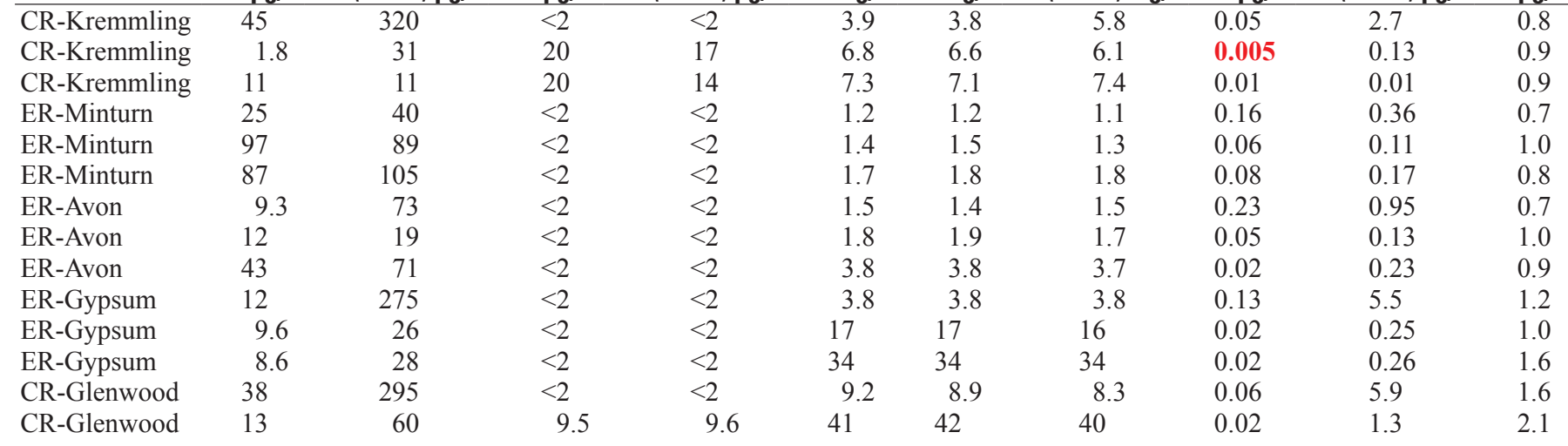


Table Al-3. Chemical and isotopic data for all water samples collected in this study.-Continued

[Site name is an abbreviation for station name; WS\#, watershed number (see fig. 5 for location); red values are replacement values; na, not analyzed; nr, not reported; CFS, cubic feet per second; IC, ion chromatography; ICP-MS, inductive coupled plasma-mass spectrometry; ICP-AES, inductive coupled plasma-atomic emission spectrometry; (avail.), available loads (operationally defined as total dissolved after acidification of unfiltered sample); ins, insufficient sample; hydrogen and oxygen isotopes reported relative to $\mathrm{V}$-SMOW and sulfur isotope values relative to V-CDT]

\begin{tabular}{|c|c|c|c|c|c|c|c|c|c|c|}
\hline Site name & $\begin{array}{l}\text { ICP-MS } \\
\text { Mn } \mu \mathrm{g} / \mathrm{L}\end{array}$ & $\begin{array}{c}\text { ICP-MS } \\
\text { Mn (avail.) } \mu \mathrm{g} / \mathrm{L}\end{array}$ & $\begin{array}{l}\text { ICP-MS } \\
\text { Mo } \mu \mathrm{g} / \mathrm{L}\end{array}$ & $\begin{array}{c}\text { ICP-MS } \\
\text { Mo (avail.) } \mu \mathrm{g} / \mathrm{L}\end{array}$ & $\begin{array}{c}\text { ICP-AES } \\
\text { Na mg/L }\end{array}$ & $\begin{array}{l}\text { ICP-MS } \\
\text { Na mg/L }\end{array}$ & $\begin{array}{c}\text { ICP-MS } \\
\text { Na (avail.) mg/L }\end{array}$ & $\begin{array}{l}\text { ICP-MS } \\
\mathrm{Nd} \mu \mathrm{g} / \mathrm{L}\end{array}$ & $\begin{array}{c}\text { ICP-MS } \\
\mathrm{Nd} \text { (avail.) } \mu \mathrm{g} / \mathrm{L}\end{array}$ & $\begin{array}{c}\text { ICP-MS } \\
\mathrm{Ni} \mu \mathrm{g} / \mathrm{L}\end{array}$ \\
\hline CR-Glenwood & 13 & 30 & 6.0 & 4.5 & 50 & 50 & 54 & 0.02 & 0.34 & 1.8 \\
\hline RF-Glenwood & 4.4 & 30 & $<2$ & $<2$ & 5.5 & 5.4 & 4.8 & 0.07 & 0.93 & 1.1 \\
\hline RF-Glenwood & 3.2 & 6 & $<2$ & $<2$ & 37 & 33 & 33 & 0.01 & 0.05 & 1.6 \\
\hline PC-Cameo & 6.2 & 83 & $<2$ & $<2$ & 7.2 & 7.5 & 7.7 & 0.13 & 3.9 & 1.4 \\
\hline PC-Cameo & 4.3 & 33 & 2.9 & 3.2 & 30 & 31 & 29 & 0.03 & 0.62 & 1.9 \\
\hline CR-Cameo & 3.4 & 24 & 4.0 & 4.2 & 44 & 45 & 42 & 0.02 & 0.57 & 1.2 \\
\hline CR-Cameo & 3.7 & 14 & 4.6 & 3.8 & 110 & 110 & 99 & 0.005 & 0.23 & 1.8 \\
\hline GR-NF & 12 & 195 & $<2$ & $<2$ & 3.7 & 3.7 & 4.2 & 0.19 & 10 & 0.8 \\
\hline GR-NF & 10 & 17 & $<2$ & $<2$ & 12 & 12 & 6.7 & 0.05 & 0.27 & 1.0 \\
\hline GR-NF & 35 & 62 & $<2$ & $<2$ & 17 & 15 & 14 & 0.02 & 0.88 & 1.2 \\
\hline GR-Tunnel & 3.3 & 18 & $<2$ & $<2$ & 5 & 4.9 & 4.4 & 0.02 & 0.16 & 0.9 \\
\hline GR-Delta & 12 & 120 & 2.4 & $<2$ & 70 & 70 & 67 & 0.005 & 5.3 & 4.2 \\
\hline UR-Ouray & 205 & 205 & $<2$ & $<2$ & 3 & 3.1 & 2.6 & 0.02 & 0.96 & 3.0 \\
\hline UR-Ouray & 305 & 315 & $<2$ & $<2$ & 6.0 & 6.1 & 5.3 & 0.05 & 1.2 & 4.9 \\
\hline UR-Ouray & 375 & 390 & $<2$ & $<2$ & 14 & 12 & 13 & 0.03 & 1.4 & 7.3 \\
\hline UR-Ridgway & 91 & 120 & $<2$ & $<2$ & 9.9 & 9.8 & 8.1 & 0.005 & 1.0 & 2.5 \\
\hline UR-Ridgway & 130 & 170 & $<2$ & $<2$ & 15 & 15 & 12 & 0.01 & 1.5 & 2.6 \\
\hline UR-Ridgway & 185 & 195 & $<2$ & $<2$ & 22 & 20 & 21 & 0.01 & 0.74 & 4.6 \\
\hline UR-Delta & 28 & 260 & 3.6 & 4.0 & 58 & 59 & 46 & 0.03 & 9.8 & 4.7 \\
\hline UR-Delta & 23 & 415 & 3.7 & $<2$ & 65 & 66 & 48 & 0.02 & 13 & 3.7 \\
\hline UR-Delta & 49 & 56 & 3.5 & 3.4 & 115 & 115 & 115 & 0.005 & 0.18 & 5.7 \\
\hline GR-Grand Jct. & 16 & 125 & $<2$ & $<2$ & 21 & 22 & 22 & 0.06 & 5.3 & 2.2 \\
\hline GR-Grand Jct. & 9 & 23 & 2.4 & 2.4 & 44 & 46 & 40 & 0.01 & 0.39 & 2.6 \\
\hline DR-Bedrock & 11 & 375 & 2.1 & $<2$ & 225 & 225 & 225 & 1.52 & 13 & 1.9 \\
\hline DR-Bedrock & 11 & 30 & $<2$ & $<2$ & 125 & 125 & 120 & 0.01 & 1.3 & 2.2 \\
\hline SM-Uravan & 20 & 130 & $<2$ & $<2$ & 7.7 & 7.9 & 7.7 & 0.04 & 2.2 & 1.6 \\
\hline SM-Uravan & 11 & 77 & 2.1 & $<2$ & 13 & 13 & 11 & 0.01 & 0.87 & 1.9 \\
\hline SM-Uravan & 24 & 29 & $<2$ & $<\overline{2}$ & 26 & 25 & 23 & 0.005 & 0.14 & 3.1 \\
\hline DR-Cisco & 1.7 & 120 & $<2$ & $<2$ & 15 & 15 & 15 & 0.03 & 3.3 & 1.8 \\
\hline DR-Cisco & 2.4 & 240 & 3.1 & 3.0 & 87 & 87 & 87 & 0.01 & 7.5 & 3.1 \\
\hline DR-Cisco & 10 & 27 & 2.4 & 2.4 & 230 & 230 & 205 & 0.01 & 0.97 & 4.1 \\
\hline CR-Cisco & 0.20 & 170 & 2.2 & 1.9 & 20 & 20 & 20 & 0.04 & 6.8 & 2.0 \\
\hline CR-Cisco & 0.3 & 36 & 4.2 & 4.5 & 48 & 54 & 52 & 0.01 & 1.1 & 2.2 \\
\hline CR-Cisco & 11 & 24 & 4.5 & 4.5 & 140 & 140 & 105 & 0.01 & 0.59 & 4.2 \\
\hline GW hot spring & 54 & 50 & $<2$ & $<2$ & 150 & 120 & 165 & 0.01 & 0.01 & 8.2 \\
\hline RUM 305 & 265 & 265 & 39 & 17 & na & 120 & 125 & 0.03 & 0.03 & 2.7 \\
\hline RUM 310 & 1,380 & 1,330 & 43 & 37 & na & $\mathrm{nr}$ & $\mathrm{nr}$ & 0.05 & 0.08 & 2.6 \\
\hline RUM 590 & 9,980 & 9,110 & 2,130 & 1,950 & na & $\mathrm{nr}$ & $\mathrm{nr}$ & 0.76 & 0.70 & 12 \\
\hline RUM 855 & 1,410 & 1,240 & 1,600 & 1,470 & na & 180 & 164 & 0.06 & 0.06 & 7.4 \\
\hline
\end{tabular}


Table Al-3. Chemical and isotopic data for all water samples collected in this study.-Continued

[Site name is an abbreviation for station name; WS\#, watershed number (see fig. 5 for location); red values are replacement values; na, not analyzed; nr, not reported; CFS, cubic feet per second; IC, ion chromatography; ICP-MS, inductive coupled plasma-mass spectrometry; ICP-AES, inductive coupled plasma-atomic emission spectrometry; (avail.), available loads (operationally defined as total dissolved after acidification of unfiltered sample); ins, insufficient sample; hydrogen and oxygen isotopes reported relative to $\mathrm{V}-\mathrm{SMOW}$ and sulfur isotope values relative to V-CDT]

\begin{tabular}{|c|c|c|c|c|c|c|c|c|c|}
\hline Site name & $\begin{array}{c}\text { ICP-MS } \\
\mathrm{Ni} \text { (avail.) } \mu \mathrm{g} / \mathrm{L}\end{array}$ & $\begin{array}{c}\text { ICP-MS } \\
\text { P mg/L }\end{array}$ & $\begin{array}{c}\text { ICP-MS } \\
\text { P (avail.) mg/L }\end{array}$ & $\begin{array}{c}\text { ICP-MS } \\
\mathrm{Pb} \mu \mathrm{g} / \mathrm{L}\end{array}$ & $\begin{array}{c}\text { ICP-MS } \\
\mathrm{Pb} \text { (avail.) } \mu \mathrm{g} / \mathrm{L}\end{array}$ & $\begin{array}{c}\text { ICP-MS } \\
\operatorname{Pr} \mu g / L\end{array}$ & $\begin{array}{c}\text { ICP-MS } \\
\operatorname{Pr}(\text { avail.) } \mu \mathrm{g} / \mathrm{L}\end{array}$ & $\begin{array}{c}\text { ICP-MS } \\
\text { Rb } \mu g / L\end{array}$ & $\begin{array}{c}\text { ICP-MS } \\
\text { Rb (avail.) } \mu \mathrm{g} / \mathrm{L}\end{array}$ \\
\hline CR-Kremmling & 0.5 & $<0.01$ & $<0.01$ & $<0.05$ & 0.20 & $<0.01$ & 0.03 & 1.1 & 1.3 \\
\hline ER-Minturn & 0.6 & $<0.01$ & $<0.01$ & 0.3 & 1.9 & 0.03 & 0.08 & 0.39 & 0.76 \\
\hline ER-Minturn & 0.5 & 0.02 & $<0.01$ & 0.2 & 0.58 & 0.01 & 0.02 & 0.52 & 0.55 \\
\hline ER-Minturn & 0.7 & $<0.01$ & $<0.01$ & 0.2 & 0.94 & 0.02 & 0.04 & 0.68 & 0.79 \\
\hline ER-Avon & 1.4 & $<0.01$ & $<0.01$ & $<0.05$ & 0.86 & $<0.01$ & 0.05 & 0.69 & 1.0 \\
\hline ER-Gypsum & 8.3 & 0.01 & 0.2 & 0.09 & 16 & 0.02 & 1.2 & 0.38 & 7.8 \\
\hline ER-Gypsum & 0.7 & $<0.01$ & 0.02 & 0.06 & 0.68 & $<0.01$ & 0.06 & 0.61 & 0.90 \\
\hline ER-Gypsum & 1.8 & 0.03 & 0.03 & 0.06 & 0.72 & $<0.01$ & 0.05 & 0.88 & 1.1 \\
\hline CR-Glenwood & 8.7 & 0.01 & 0.2 & 0.06 & 12 & 0.01 & 1.31 & 0.65 & 8.9 \\
\hline RF-Glenwood & 1.6 & $<0.01$ & $<0.01$ & 0.2 & 0.61 & $<0.01$ & 0.01 & 1.4 & 1.4 \\
\hline PC-Cameo & 4.0 & 0.03 & 0.1 & $<0.05$ & 1.7 & 0.03 & 0.90 & 0.46 & 4.8 \\
\hline PC-Cameo & 1.3 & 0.03 & 0.06 & 0.08 & 0.40 & $<0.01$ & 0.16 & 1.7 & 2.5 \\
\hline PC-Cameo & 2.0 & $<0.01$ & $<0.01$ & $<0.05$ & 0.40 & $<0.01$ & 0.11 & 1.7 & 2.2 \\
\hline CR-Cameo & 3.6 & $<0.01$ & 0.1 & $<0.05$ & 3.7 & $<0.01$ & 0.61 & 1.2 & 4.9 \\
\hline CR-Cameo & 0.8 & $<0.01$ & 0.02 & 0.2 & 1.2 & $<0.01$ & 0.14 & 2.2 & 3.1 \\
\hline CR-Cameo & 1.5 & $<0.01$ & $<0.01$ & 0.06 & 0.40 & $<0.01$ & 0.04 & 4.4 & 4.8 \\
\hline GR-NF & 6.8 & $<0.01$ & 0.2 & 0.06 & 6.5 & 0.04 & 2.4 & 0.36 & 11 \\
\hline GR-NF & 0.4 & 0.06 & $<0.01$ & 0.06 & 0.2 & $<0.01$ & 0.06 & 0.84 & 0.44 \\
\hline GR-NF & 1.4 & $<0.01$ & 0.01 & $<0.05$ & 0.89 & $<0.01$ & 0.19 & 0.27 & 1.0 \\
\hline GR-Tunnel & 0.4 & $<0.01$ & 0.01 & $<0.05$ & 0.20 & $<0.01$ & 0.04 & 1.4 & 1.8 \\
\hline GR-Tunnel & 0.4 & $<0.01$ & $<0.01$ & 0.06 & 0.2 & $<0.01$ & 0.02 & 1.3 & 1.6 \\
\hline UR-Ridgway & 1.6 & $<0.01$ & 0.02 & $<0.05$ & 4.8 & $<0.01$ & 0.23 & 1.8 & 2.6 \\
\hline UR-Ridgway & 2.4 & $<0.01$ & 0.05 & $<0.05$ & 7.6 & $<0.01$ & 0.33 & 2.7 & 3.6 \\
\hline UR-Ridgway & 5.0 & $<0.01$ & $<0.01$ & $<0.05$ & 3.1 & $<0.01$ & 0.16 & 4.8 & 5.0 \\
\hline UR-Delta & 10 & 0.06 & 0.4 & $<0.05$ & 13 & $<0.01$ & 2.3 & 1.3 & 16 \\
\hline UR-Delta & 15 & 0.03 & 0.5 & $<0.05$ & 18 & $<0.01$ & 2.8 & 1.8 & 9.9 \\
\hline UR-Delta & 5.5 & $<0.01$ & 0.01 & $<0.05$ & 0.40 & $<0.01$ & 0.05 & 1.8 & 2.0 \\
\hline GR-Grand Jct. & 5.5 & $<0.01$ & 0.2 & 0.07 & 4.6 & $<0.01$ & 1.2 & 1.0 & 7.3 \\
\hline GR-Grand Jct. & 1.4 & $<0.01$ & $<0.01$ & $<0.05$ & 0.66 & $<0.01$ & 0.09 & 1.6 & 2.1 \\
\hline GR-Grand Jct. & 1.6 & $<0.01$ & $<0.01$ & $<0.05$ & 0.20 & $<0.01$ & 0.08 & 2.1 & 2.3 \\
\hline CR-State line & 5.0 & 0.01 & 0.2 & 0.09 & 7.1 & $<0.01$ & 1.2 & 0.95 & 7.3 \\
\hline CR-State line & 1.9 & $<0.01$ & 0.05 & 0.06 & 1.9 & $<0.01$ & 0.35 & 1.8 & 3.2 \\
\hline CR-State line & 3.0 & $<0.01$ & $<0.01$ & $<0.05$ & 0.83 & $<0.01$ & 0.14 & 2.7 & 3.4 \\
\hline DR-Dolores & 5.7 & $<0.01$ & 0.2 & 0.2 & 19 & 0.05 & 2.0 & 0.78 & 9.0 \\
\hline DR-Dolores & 0.4 & $<0.01$ & $<0.01$ & $<0.05$ & 0.20 & $<0.01$ & 0.03 & 3.8 & 4.2 \\
\hline DR-Dolores & 1.0 & $<0.01$ & $<0.01$ & $<0.05$ & 0.2 & $<0.01$ & 0.02 & 5.9 & 6.3 \\
\hline
\end{tabular}


Table Al-3. Chemical and isotopic data for all water samples collected in this study.-Continued

[Site name is an abbreviation for station name; WS\#, watershed number (see fig. 5 for location); red values are replacement values; na, not analyzed; nr, not reported; CFS, cubic feet per second; IC, ion chromatography; ICP-MS, inductive coupled plasma-mass spectrometry; ICP-AES, inductive coupled plasma-atomic emission spectrometry; (avail.), available loads (operationally defined as total dissolved after acidification of unfiltered sample); ins, insufficient sample; hydrogen and oxygen isotopes reported relative to V-SMOW and sulfur isotope values relative to V-CDT]

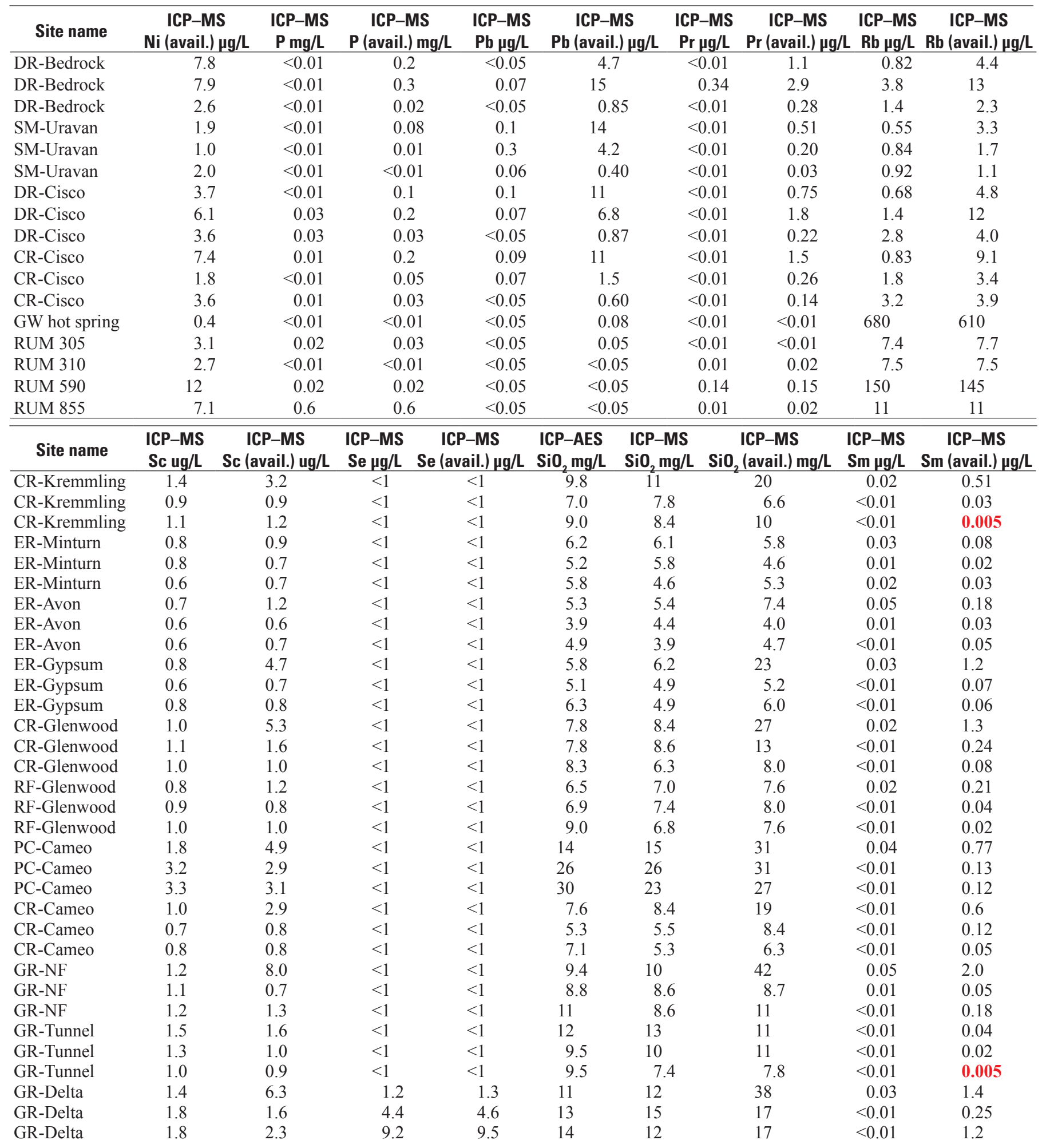


Table Al-3. Chemical and isotopic data for all water samples collected in this study.-Continued

[Site name is an abbreviation for station name; WS\#, watershed number (see fig. 5 for location); red values are replacement values; na, not analyzed; nr, not reported; CFS, cubic feet per second; IC, ion chromatography; ICP-MS, inductive coupled plasma-mass spectrometry; ICP-AES, inductive coupled plasma-atomic emission spectrometry; (avail.), available loads (operationally defined as total dissolved after acidification of unfiltered sample); ins, insufficient sample; hydrogen and oxygen isotopes reported relative to $\mathrm{V}$-SMOW and sulfur isotope values relative to $\mathrm{V}$-CDT]

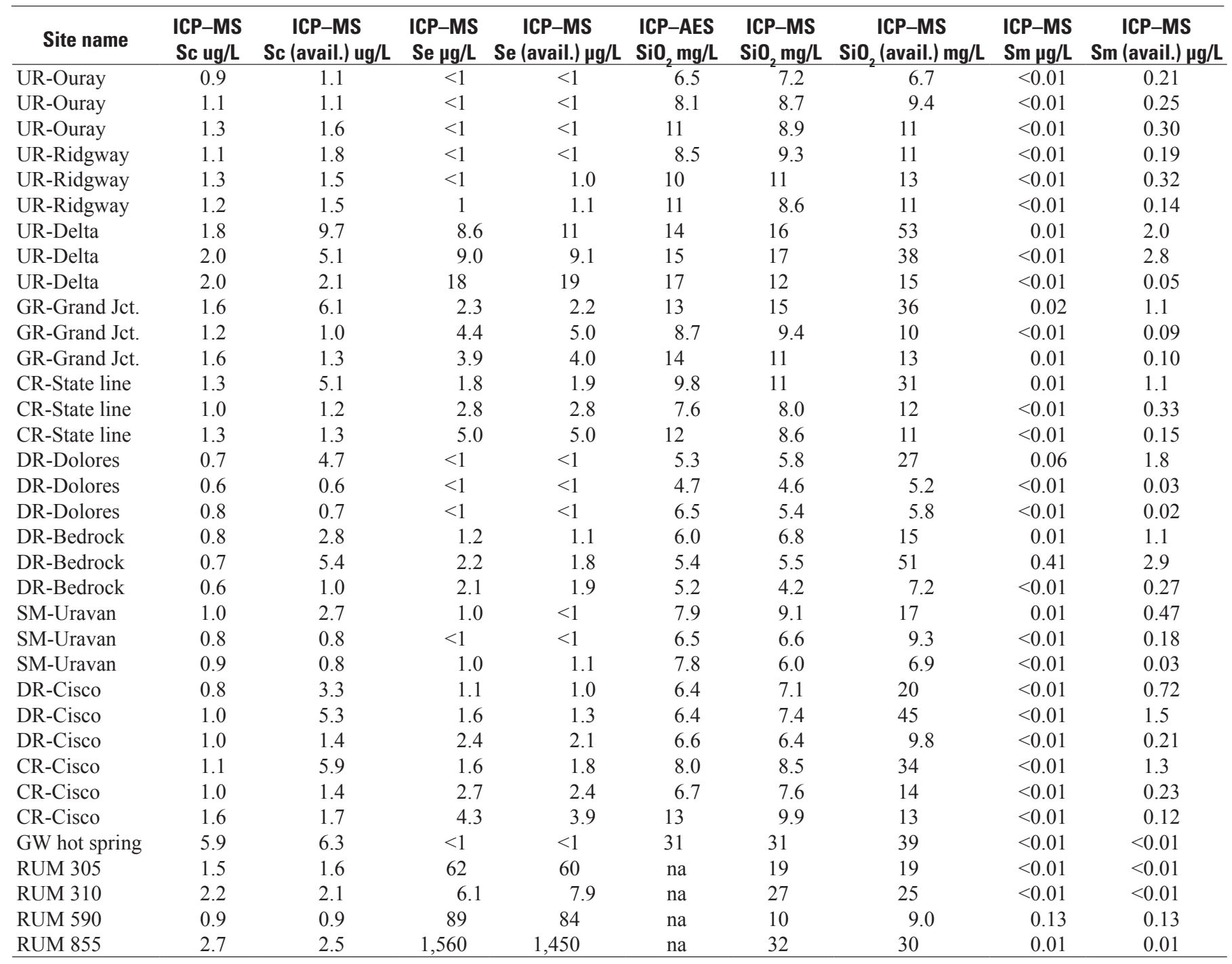

\begin{tabular}{|c|c|c|c|c|c|c|c|c|c|c|}
\hline Site name & $\begin{array}{c}\text { ICP-AES } \\
\text { Sr } \mu g / L\end{array}$ & $\begin{array}{c}\text { ICP-MS } \\
\text { Sr } \mu g / L\end{array}$ & $\begin{array}{c}\text { ICP-MS } \\
\text { Sr (avail.) } \mu \mathrm{g} / \mathrm{L}\end{array}$ & $\begin{array}{c}\text { ICP-MS } \\
\mathrm{Tb} \mu \mathrm{g} / \mathrm{L}\end{array}$ & $\begin{array}{c}\text { ICP-MS } \\
\text { Tb (avail.) } \mu \mathrm{g} / \mathrm{L}\end{array}$ & $\begin{array}{c}\text { ICP-MS } \\
\text { Ti ug/L }\end{array}$ & $\begin{array}{c}\text { ICP-MS } \\
\text { Ti (avail.) ug/L }\end{array}$ & $\begin{array}{c}\text { ICP-MS } \\
\text { U } \mu \mathrm{g} / \mathrm{L}\end{array}$ & $\begin{array}{c}\text { ICP-MS } \\
\text { U (avail.) } \mu \mathrm{g} / \mathrm{L}\end{array}$ & $\begin{array}{c}\text { ICP-MS } \\
V_{\mu g} / \mathrm{L}\end{array}$ \\
\hline CR-Kremmling & 93 & 86 & 180 & $<0.005$ & 0.06 & 0.3 & 8.7 & 0.34 & 1.0 & 0.6 \\
\hline CR-Kremmling & 150 & 140 & 155 & $<0.005$ & 0.003 & 0.8 & 1.3 & 0.3 & 0.89 & 1.4 \\
\hline ER-Minturn & 49 & 43 & 46 & 0.005 & 0.01 & 0.7 & 5.5 & 0.49 & 0.48 & 0.3 \\
\hline ER-Minturn & 63 & 58 & 55 & $<0.005$ & 0.003 & 0.3 & 0.9 & 0.69 & 0.54 & $<0.5$ \\
\hline ER-Minturn & 55 & 52 & 56 & $<0.005$ & 0.005 & 0.3 & 1.2 & 0.43 & 0.47 & $<0.5$ \\
\hline ER-Avon & 130 & 130 & 135 & $<0.005$ & 0.005 & 0.3 & 5.3 & 0.55 & 0.7 & $<0.5$ \\
\hline ER-Gypsum & 150 & 135 & 200 & $<0.005$ & 0.15 & 0.6 & 66 & 0.62 & 1.1 & 0.5 \\
\hline ER-Gypsum & 375 & 350 & 405 & $<0.005$ & 0.008 & 0.8 & 2.7 & 0.56 & 0.75 & $<0.5$ \\
\hline ER-Gypsum & 585 & 585 & 605 & $<0.005$ & 0.009 & 1.5 & 2.6 & 0.92 & 1.1 & $<0.5$ \\
\hline CR-Glenwood & 170 & 150 & 210 & $<0.005$ & 0.15 & 0.6 & 63 & 0.72 & 1.1 & 0.8 \\
\hline CR-Glenwood & 385 & 380 & 395 & $<0.005$ & 0.03 & 1.1 & 20 & 1.4 & 1.4 & 0.8 \\
\hline
\end{tabular}


Table Al-3. Chemical and isotopic data for all water samples collected in this study.-Continued

[Site name is an abbreviation for station name; WS\#, watershed number (see fig. 5 for location); red values are replacement values; na, not analyzed; nr, not reported; CFS, cubic feet per second; IC, ion chromatography; ICP-MS, inductive coupled plasma-mass spectrometry; ICP-AES, inductive coupled plasma-atomic emission spectrometry; (avail.), available loads (operationally defined as total dissolved after acidification of unfiltered sample); ins, insufficient sample; hydrogen and oxygen isotopes reported relative to $\mathrm{V}$-SMOW and sulfur isotope values relative to V-CDT]

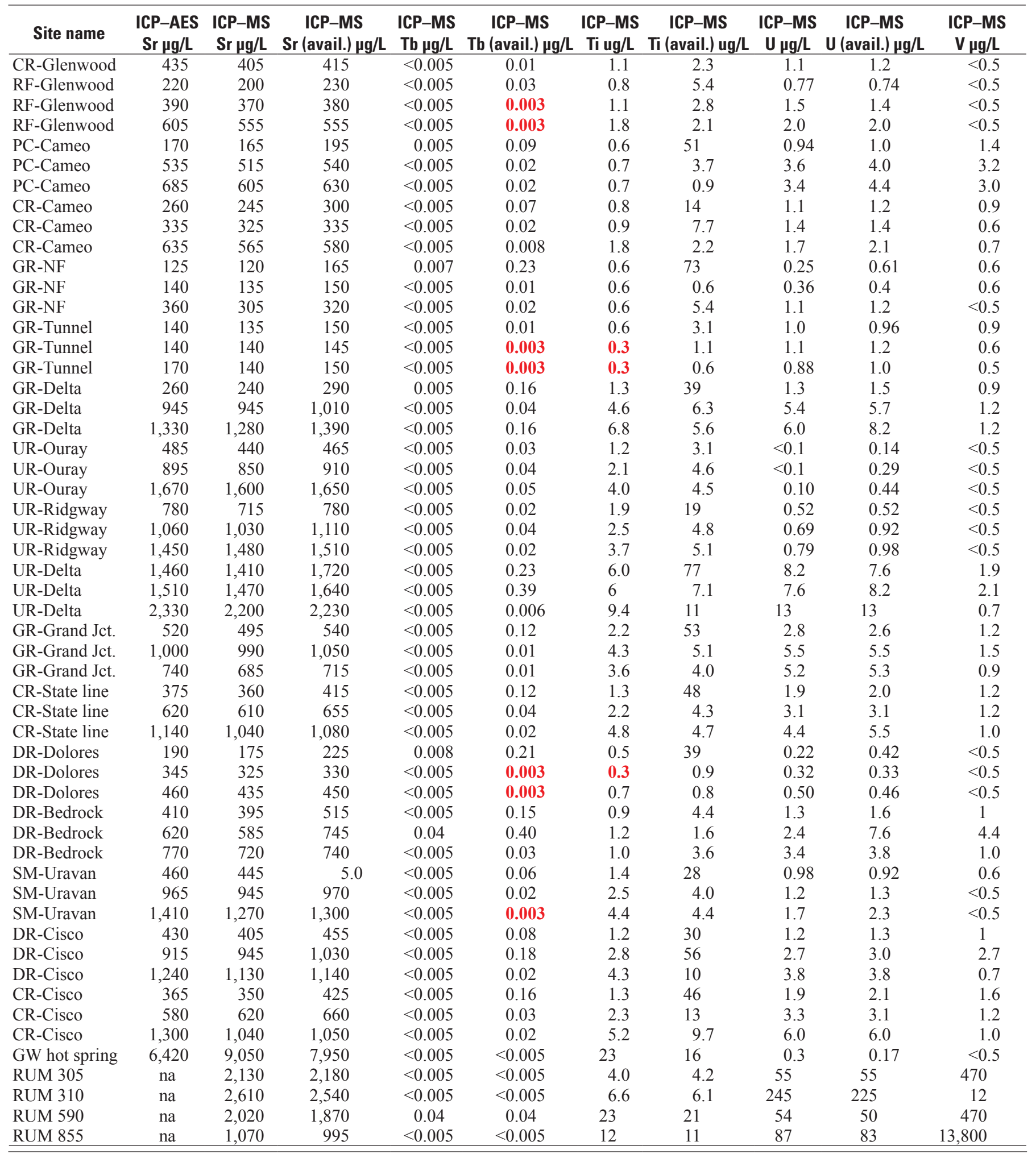




\section{Salinization of the Upper Colorado River-Fingerprinting Geologic Salt Sources}

Table Al-3. Chemical and isotopic data for all water samples collected in this study.-Continued

[Site name is an abbreviation for station name; WS\#, watershed number (see fig. 5 for location); red values are replacement values; na, not analyzed; nr, not reported; CFS, cubic feet per second; IC, ion chromatography; ICP-MS, inductive coupled plasma-mass spectrometry; ICP-AES, inductive coupled plasma-atomic emission spectrometry; (avail.), available loads (operationally defined as total dissolved after acidification of unfiltered sample); ins, insufficient sample; hydrogen and oxygen isotopes reported relative to $\mathrm{V}$-SMOW and sulfur isotope values relative to $\mathrm{V}$-CDT]

\begin{tabular}{|c|c|c|c|c|c|c|c|c|}
\hline Site name & $\begin{array}{c}\text { ICP-MS } \\
\text { V (avail.) } \mu \mathrm{g} / \mathrm{L}\end{array}$ & $\begin{array}{c}\text { ICP-MS } \\
Y \mu g / L\end{array}$ & $\begin{array}{c}\text { ICP-MS } \\
Y \text { (avail.) } \mu \mathrm{g} / \mathrm{L}\end{array}$ & $\begin{array}{l}\text { ICP-MS } \\
\text { Yb } \mu g / L\end{array}$ & $\begin{array}{c}\text { ICP-MS } \\
\text { Yb (avail.) } \mu \mathrm{g} / \mathrm{L}\end{array}$ & $\begin{array}{c}\text { ICP-MS } \\
\text { Zn } \mu g / L\end{array}$ & $\begin{array}{c}\text { ICP-MS } \\
\text { Zn } \mu g / L\end{array}$ & $\begin{array}{c}\text { ICP-MS } \\
\text { Zn (avail.) } \mu \mathrm{g} / \mathrm{L}\end{array}$ \\
\hline CR-Kremmling & 4.0 & 0.05 & 1.6 & 0.006 & 0.13 & $<10$ & 2.1 & 17 \\
\hline CR-Kremmling & 0.3 & 0.01 & 0.08 & $<0.005$ & 0.01 & $<10$ & 1.2 & 3.5 \\
\hline ER-Minturn & 0.5 & 0.13 & 0.28 & 0.01 & 0.02 & 56 & 54 & 52 \\
\hline ER-Minturn & 0.3 & 0.05 & 0.08 & $<0.005$ & 0.01 & 70 & 65 & 76 \\
\hline ER-Minturn & 0.3 & 0.06 & 0.12 & 0.006 & 0.01 & 82 & 83 & 105 \\
\hline ER-Avon & 0.3 & 0.02 & 0.16 & $<0.005$ & 0.01 & 27 & 26 & 53 \\
\hline ER-Gypsum & 8.8 & 0.13 & 3.5 & 0.01 & 0.26 & $<10$ & 4.3 & 135 \\
\hline ER-Gypsum & 0.7 & 0.03 & 0.23 & $<0.005$ & 0.01 & 12 & 6.4 & 14 \\
\hline ER-Gypsum & 0.7 & 0.03 & 0.24 & $<0.005$ & 0.02 & 12 & 4.3 & 17 \\
\hline CR-Glenwood & 9.8 & 0.07 & 3.6 & 0.007 & 0.27 & 10 & 1.8 & 99 \\
\hline CR-Glenwood & 2.2 & 0.03 & 0.60 & $<0.005$ & 0.05 & 24 & 3.1 & 7.7 \\
\hline PC-Cameo & 5.1 & 0.16 & 2.0 & 0.02 & 0.18 & $<10$ & 0.7 & 15 \\
\hline PC-Cameo & 3.8 & 0.07 & 0.36 & $<0.005$ & 0.03 & $<10$ & 1.4 & 27 \\
\hline PC-Cameo & 3.4 & 0.04 & 0.50 & $<0.005$ & 0.04 & $<10$ & 0.7 & 3 \\
\hline CR-Cameo & 4.4 & 0.05 & 1.7 & $<0.005$ & 0.12 & $<10$ & 3.0 & 43 \\
\hline CR-Cameo & 1.2 & 0.03 & 0.34 & $<0.005$ & 0.02 & $<10$ & 3.6 & 6.2 \\
\hline CR-Cameo & 0.9 & 0.03 & 0.18 & $<0.005$ & 0.01 & $<10$ & 1.3 & 2.8 \\
\hline GR-NF & 10 & 0.22 & 5.3 & 0.02 & 0.42 & 18 & 13 & 32 \\
\hline GR-NF & 0.5 & 0.08 & 0.22 & 0.006 & 0.02 & 505 & 545 & 1.5 \\
\hline GR-NF & 1.2 & 0.04 & 0.55 & 0.006 & 0.04 & $<10$ & 1.8 & 4.3 \\
\hline GR-Tunnel & 1.0 & 0.04 & 0.16 & 0.005 & 0.02 & $<10$ & 0.7 & 2.0 \\
\hline GR-Tunnel & 0.7 & 0.03 & 0.09 & $<0.005$ & 0.01 & $<10$ & 1.1 & 5.0 \\
\hline GR-Tunnel & 0.5 & 0.02 & 0.04 & $<0.005$ & 0.003 & $<10$ & 0.8 & 1.4 \\
\hline
\end{tabular}


Table Al-3. Chemical and isotopic data for all water samples collected in this study.-Continued

[Site name is an abbreviation for station name; WS\#, watershed number (see fig. 5 for location); red values are replacement values; na, not analyzed; nr, not reported; CFS, cubic feet per second; IC, ion chromatography; ICP-MS, inductive coupled plasma-mass spectrometry; ICP-AES, inductive coupled plasma-atomic emission spectrometry; (avail.), available loads (operationally defined as total dissolved after acidification of unfiltered sample); ins, insufficient sample; hydrogen and oxygen isotopes reported relative to $\mathrm{V}$-SMOW and sulfur isotope values relative to $\mathrm{V}$-CDT]

\begin{tabular}{|c|c|c|c|c|c|c|c|c|}
\hline Site name & $\begin{array}{c}\text { ICP-MS } \\
\text { V (avail.) } \mu \mathrm{g} / \mathrm{L}\end{array}$ & $\begin{array}{c}\text { ICP-MS } \\
Y \mu g / L\end{array}$ & $\begin{array}{c}\text { ICP-MS } \\
Y \text { (avail.) } \mu \mathrm{g} / \mathrm{L}\end{array}$ & $\begin{array}{l}\text { ICP-MS } \\
\text { Yb } \mu \mathrm{g} / \mathrm{L}\end{array}$ & $\begin{array}{c}\text { ICP-MS } \\
\text { Yb (avail.) } \mu \mathrm{g} / \mathrm{L}\end{array}$ & $\begin{array}{l}\text { ICP-MS } \\
\mathrm{Zn} \mu \mathrm{g} / \mathrm{L}\end{array}$ & $\begin{array}{l}\text { ICP-MS } \\
\mathrm{Zn} \mu \mathrm{g} / \mathrm{L}\end{array}$ & $\begin{array}{c}\text { ICP-MS } \\
\text { Zn (avail.) } \mu \mathrm{g} / \mathrm{L}\end{array}$ \\
\hline UR-Ouray & 0.8 & 0.04 & 0.99 & $<0.005$ & 0.07 & 180 & 195 & 290 \\
\hline UR-Ouray & 0.3 & 0.05 & 1.3 & $<0.005$ & 0.08 & 205 & 215 & 335 \\
\hline UR-Ridgway & 1.5 & 0.03 & 1.0 & $<0.005$ & 0.07 & 29 & 24 & 105 \\
\hline UR-Ridgway & 0.3 & 0.03 & 0.63 & $<0.005$ & 0.04 & 54 & 49 & 145 \\
\hline UR-Delta & 19 & 0.07 & 5.9 & 0.006 & 0.38 & 16 & 5.3 & 57 \\
\hline GR-Grand Jct. & 8.5 & 0.09 & 2.9 & 0.008 & 0.22 & 13 & 4.6 & 26 \\
\hline GR-Grand Jct. & 2.0 & 0.04 & 0.25 & $<0.005$ & 0.02 & $<10$ & 1.5 & 3.7 \\
\hline GR-Grand Jct. & 1.0 & 0.06 & 0.21 & 0.005 & 0.01 & $<10$ & 2.3 & 2.7 \\
\hline CR-State line & 7.7 & 0.06 & 2.7 & 0.005 & 0.21 & 15 & 6.8 & 25 \\
\hline CR-State line & 2.7 & 0.04 & 0.94 & $<0.005$ & 0.07 & $<10$ & 1.1 & 8.9 \\
\hline CR-State line & 1.9 & 0.04 & 0.54 & $<0.005$ & 0.04 & 12 & 1.6 & 5.1 \\
\hline DR-Bedrock & 42 & 0.56 & 7.8 & 0.01 & 0.56 & $<10$ & 1.2 & 34 \\
\hline DR-Bedrock & 3.0 & 0.03 & 0.63 & $<0.005$ & 0.04 & $<10$ & 1.1 & 4.4 \\
\hline SM-Uravan & 3.1 & 0.07 & 1.3 & 0.005 & 0.09 & 16 & 12 & 73 \\
\hline SM-Uravan & 1.2 & 0.03 & 0.52 & $<0.005$ & 0.03 & 12 & 5.0 & 29 \\
\hline SM-Uravan & 0.3 & 0.03 & 0.10 & $<0.005$ & 0.01 & 15 & 10 & 12 \\
\hline DR-Cisco & 6.5 & 0.04 & 1.9 & $<0.005$ & 0.14 & 10 & 4.8 & 49 \\
\hline DR-Cisco & 13 & 0.04 & 3.3 & $<0.005$ & 0.23 & 13 & 4.6 & 29 \\
\hline DR-Cisco & 2.6 & 0.04 & 0.53 & $<0.005$ & 0.04 & 12 & 3.5 & 7.7 \\
\hline CR-Cisco & 11 & 0.04 & 3.8 & $<0.005$ & 0.26 & 82 & 75 & 42 \\
\hline CR-Cisco & 2.9 & 0.03 & 0.60 & $<0.005$ & 0.05 & 12 & 5.5 & 9.3 \\
\hline CR-Cisco & 1.7 & 0.04 & 0.34 & $<0.005$ & 0.02 & 14 & 3.1 & 6.8 \\
\hline GW hot spring & $<0.5$ & 0.09 & 0.07 & $<0.005$ & 0.01 & 23 & 3.6 & 4.4 \\
\hline
\end{tabular}




\section{Appendix II. Chemical Loads for Major Chemical Elements and Total Solutes}

Table All-1. Conductivity and chemical load (tonnes/day) for major chemical elements.

[(aq), dissolved loads; (avail); available loads (operationally defined as total dissolved after acidification); Al (aq), Mn (aq) <1 tonne/day. Full station name in Table AI-3]

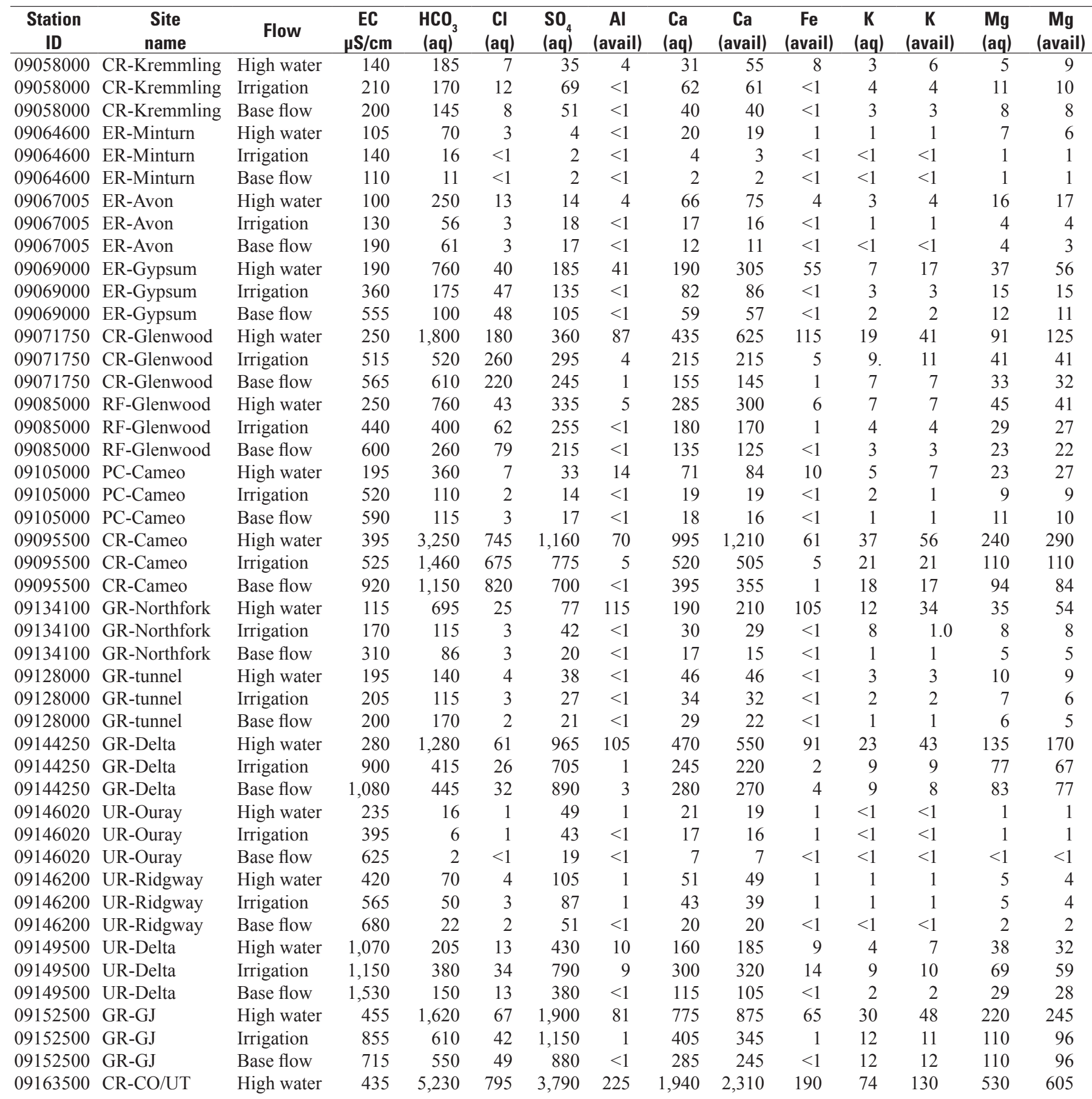


Table All-1. Conductivity and chemical load (tonnes/day) for major chemical elements._- Continued

[(aq), dissolved loads; (avail); available loads (operationally defined as total dissolved after acidification); Al (aq), Mn (aq) <1 tonne/day. Full station name in Table AI-3]

\begin{tabular}{|c|c|c|c|c|c|c|c|c|c|c|c|c|c|c|}
\hline $\begin{array}{c}\text { Field } \\
\text { No. } \\
\end{array}$ & Site & Flow & $\begin{array}{c}\text { EC, } \\
\mu S / c m)\end{array}$ & $\begin{array}{c}\mathrm{HCO}_{3} \\
(\mathrm{aq})\end{array}$ & $\begin{array}{c}\mathrm{CI} \\
(\mathrm{aq})\end{array}$ & $\begin{array}{l}\mathrm{SO}_{4} \\
(\mathrm{aq})\end{array}$ & $\begin{array}{c}\text { Al } \\
\text { (avail) }\end{array}$ & $\begin{array}{c}\mathrm{Ca} \\
(\mathrm{aq})\end{array}$ & $\begin{array}{c}\text { Ca } \\
\text { (avail) }\end{array}$ & $\begin{array}{c}\mathrm{Fe} \\
\text { (avail) }\end{array}$ & $\begin{array}{c}K \\
\text { (aq) }\end{array}$ & $\begin{array}{c}K \\
\text { (avail) } \\
\end{array}$ & $\begin{array}{l}\mathrm{Mg} \\
\text { (aq) }\end{array}$ & $\begin{array}{c}\text { Mg } \\
\text { (avail) }\end{array}$ \\
\hline 09163500 & $\mathrm{CO} / \mathrm{UT}$ & Base flow & 1,090 & 1,910 & 755 & 3,140 & 4 & 1,140 & 1,000 & 4 & 36 & 35 & 335 & 295 \\
\hline 09166500 & Dolores & Irrigation & 265 & 63 & 4 & 18 & $<1$ & 22 & 20 & $<1$ & 1 & 1 & 3 & 3 \\
\hline 09166500 & Dolores & Base flow & 330 & 35 & 3 & 12 & $<1$ & 14 & 12 & $<1$ & 1 & 1 & 2 & 2 \\
\hline 09171100 & Bedrock & High water & 400 & 425 & 57 & 185 & 8 & 140 & 220 & 12 & 7 & 9 & 30 & 42 \\
\hline 09177000 & -Uravan & High water & 350 & 320 & 13 & 245 & 7 & 140 & 140 & 5 & 4 & 5 & 32 & 31 \\
\hline 09177000 & -Uravan & Irrigation & 565 & 63 & 3 & 93 & $<1$ & 39 & 35 & $<1$ & 1 & 1 & 9 & 8 \\
\hline 09177000 & -Uravan & Base flow & 750 & 60 & 4 & 87 & $<1$ & 33 & 29 & $<1$ & 1 & 1 & 10 & 9 \\
\hline 09180000 & Cisco & High water & 375 & 555 & 67 & 310 & 16 & 200 & 230 & 13 & 8 & 13 & 42 & 48 \\
\hline 09180000 & Cisco & Irrigation & 1,070 & 100 & 99 & 115 & 5 & 50 & 57 & 3 & 4 & 6 & 13 & 15 \\
\hline Site & \multicolumn{2}{|c|}{ Flow } & $\begin{array}{l}\mathbf{M n} \\
\text { avail) }\end{array}$ & \multicolumn{2}{|l|}{$\begin{array}{l}\mathrm{Na} \\
\text { (aq) }\end{array}$} & $\begin{array}{c}\mathrm{Na} \\
\text { (avail) }\end{array}$ & \multicolumn{2}{|c|}{$\begin{array}{l}\mathrm{SiO}_{2} \\
(\mathrm{aq})\end{array}$} & \multicolumn{2}{|c|}{$\begin{array}{c}\mathrm{SiO}_{2} \\
\text { (avail) }\end{array}$} & \multicolumn{2}{|l|}{$\begin{array}{c}\text { Total } \\
\text { (aq) }\end{array}$} & \multicolumn{2}{|c|}{$\begin{array}{l}\% \text { CR } \\
\text { Cisco }\end{array}$} \\
\hline CR-Kremmling & \multicolumn{2}{|c|}{ High water } & 1 & \multicolumn{2}{|l|}{11} & 18 & \multicolumn{2}{|r|}{32} & \multicolumn{2}{|c|}{60} & \multicolumn{2}{|l|}{310} & 2 & 2 \\
\hline CR-Kremmling & Irrigati & $<$ & & 16 & & 15 & & 19 & 16 & & 365 & & 4 & 4 \\
\hline CR-Kremmling & Base fl & $<$ & & 13 & & 14 & & 15 & 19 & & 280 & & 3 & 3 \\
\hline ER-Minturn & High w & ter & & 2 & & 2 & & 9 & 9 & & 115 & & $<1$ & \\
\hline ER-Minturn & Irrigati & $<$ & & $<1$ & & $<1$ & & 1 & 1 & & 25 & & $<1$ & \\
\hline ER-Minturn & Base fl & $<$ & & $<1$ & & $<1$ & & 1 & 1 & & 18 & & $<1$ & \\
\hline ER-Avon & High w & ter & & 8 & & 8 & & 29 & 39 & & 395 & & 2 & \\
\hline ER-Avon & Irrigati & $<$ & & 2 & & 2 & & 5 & 4 & & 105 & & 1 & 1 \\
\hline ER-Avon & Base fl & $<$ & & 2 & & 2 & & 2 & 2 & & 100 & & 1 & 1 \\
\hline ER-Gypsum & High w & & 2 & 33 & & 34 & & 55 & 205 & & 1,310 & & 8 & 8 \\
\hline PC-Cameo & High w & ter & & 26 & & 27 & & 52 & 110 & & 575 & & 3 & 3 \\
\hline PC-Cameo & Irrigati & $<$ & & 12 & & 11 & & 10 & 12 & & 175 & & 2 & 2 \\
\hline PC-Cameo & Base fl & $<$ & & 14 & & 13 & & 8 & 10 & & 190 & & 2 & 2 \\
\hline CR-Cameo & High w & & 2 & 695 & & 720 & & 225 & 510 & & 7,450 & & 44 & \\
\hline CR-Cameo & Irrigati & $<$ & & 545 & & 515 & & 68 & 105 & & 4,170 & & 51 & \\
\hline CR-Cameo & Base fl & $<$ & & 670 & & 600 & & 32 & 38 & & 3,870 & & 40 & \\
\hline GR-Northfork & High w & & 2 & 47 & & 53 & & 130 & 540 & & 1,210 & & 7 & 7 \\
\hline GR-Northfork & Irrigati & $<$ & & 20 & & 11 & & 15 & 15 & & 240 & & 3 & 3 \\
\hline GR-Northfork & Base fl & $<$ & & 7 & & 7 & & 4 & 6 & & 145 & & 2 & 2 \\
\hline GR-tunnel & High w & ter & & 9 & & 8 & & 24 & 21 & & 275 & & 2 & \\
\hline GR-tunnel & Irrigati & $<$ & & 6 & & 6 & & 13 & 14 & & 205 & & 3 & \\
\hline GR-tunnel & Base fl & $<$ & & 5 & & 4 & & 7 & 8 & & 240 & & 3 & 3 \\
\hline GR-Delta & High w & ter & 2 & 180 & & 195 & & 195 & 600 & & 3,310 & & 19 & \\
\hline
\end{tabular}


Table All-1. Conductivity and chemical load (tonnes/day) for major chemical elements._Continued

[(aq), dissolved loads; (avail); available loads (operationally defined as total dissolved after acidification); $\mathrm{Al}$ (aq), Mn (aq) $<1$ tonne/day. Full station name in Table AI-3]

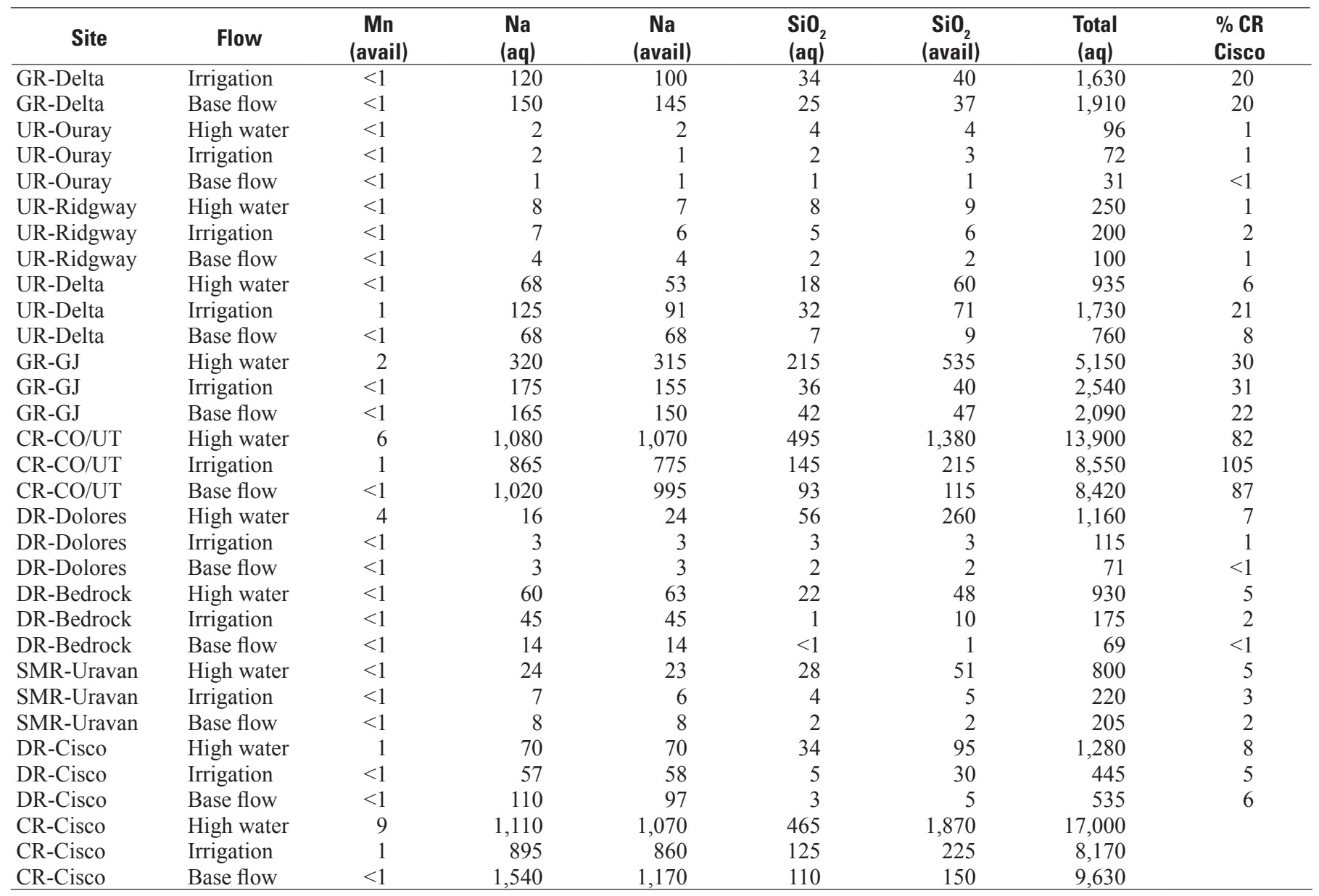




\section{Appendix III. Chemical, Isotopic, and Mineralogical Data for All Geologic Samples Collected in This Study}

Table All-1. Metadata (analytical method, detection limit, the number of samples with censored data, the percent of samples with replaced values, and the replacement value) for reported concentrations.

[Replacement (red) values $(0.5 \times$ detection limit) are used when censored values were reported for $\geq 20$ percent of the samples (14 samples or less). For elements with the number censored = "many," less than concentrations are reported. For tables AIII-1—4: ICP-MS, inductive coupled plasma-mass spectrometry; ICP-AES, inductive coupled plasma-atomic emission spectrometry; HYD, hydride generation atomic adsorption spectrometry; COMB, combustion; CVAA, cold vapor atomic adsorption spectrometry; GF, graphite furnace; ISE, ion selective electrode; nd, not determined; ins, insufficient sample]

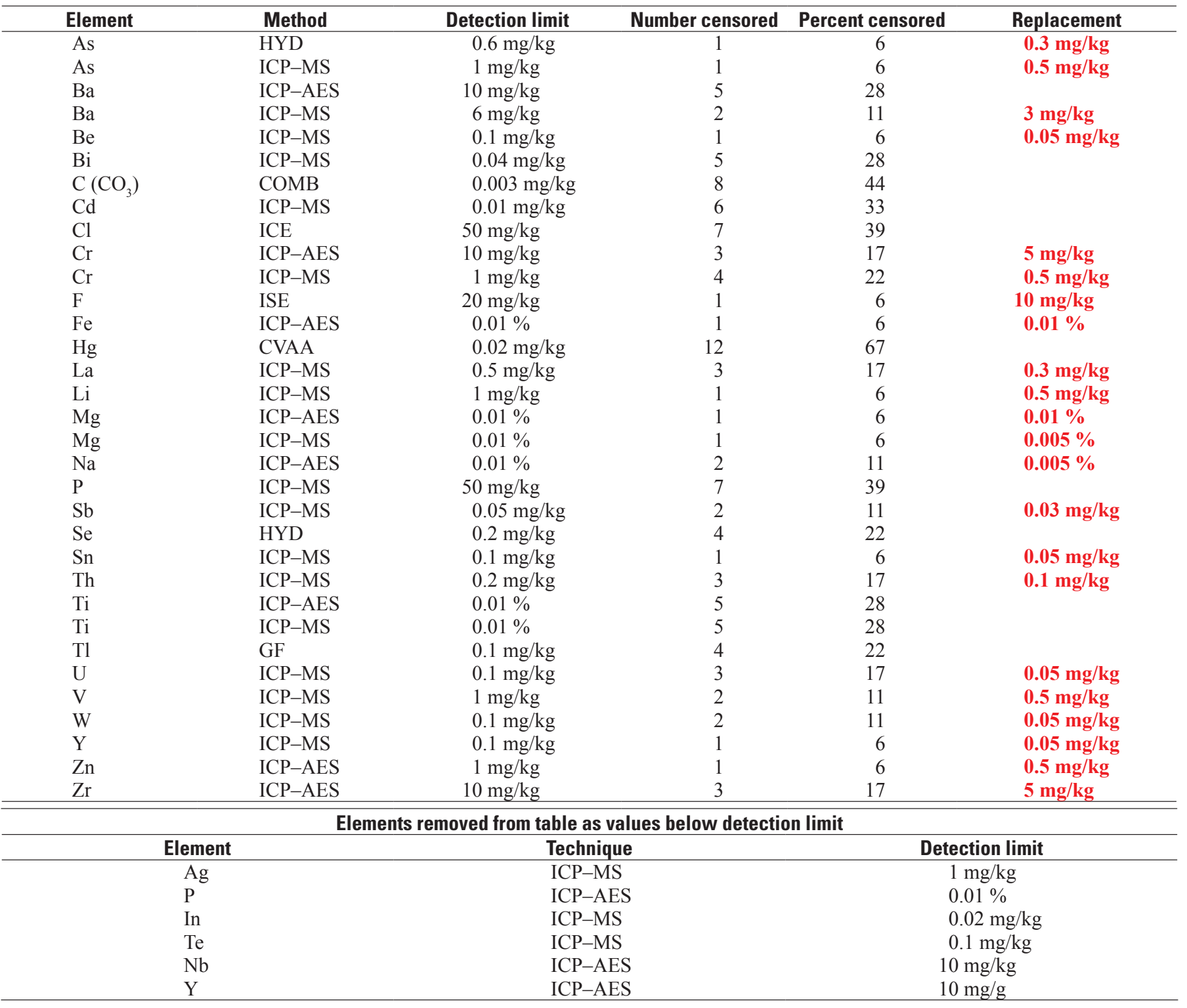


Table Alll-2. Chemical data for all geologic samples collected in this study.

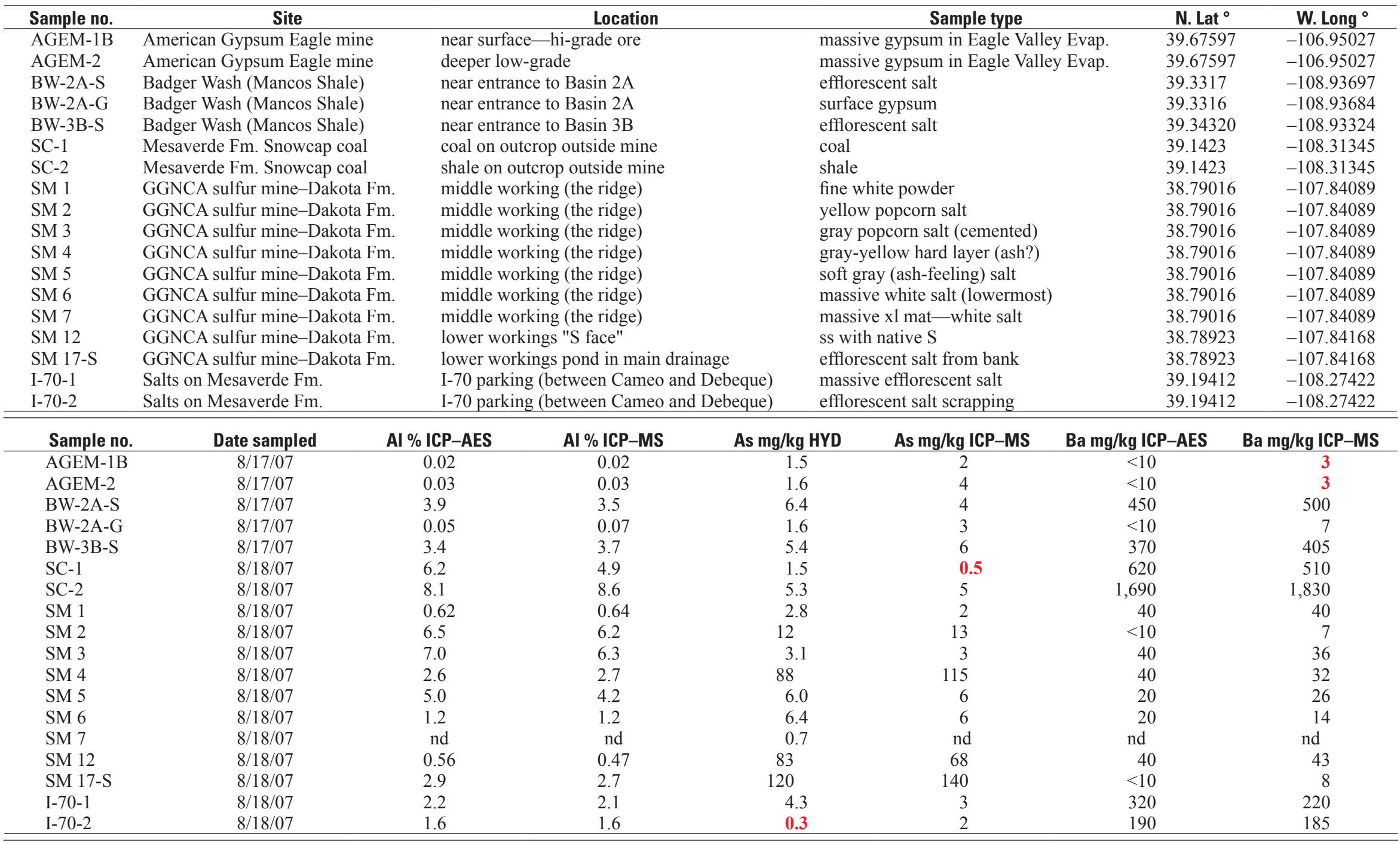


Table Alll-2. Chemical data for all geologic samples collected in this study.-Continued

\begin{tabular}{|c|c|c|c|c|c|c|}
\hline Sample no. & Be mg/kg ICP-MS & Bi mg/kg ICP-MS & Ca \% ICP-AES & Ca \% ICP-MS & C (tot) \% COMB & C (org) \% COMB \\
\hline AGEM-1B & 0.05 & $<0.04$ & 24 & 27 & 0.02 & 0.02 \\
\hline AGEM-2 & 0.1 & $<0.04$ & 29 & 31 & 0.09 & 0.01 \\
\hline BW-2A-S & 1.4 & 0.19 & 4.9 & 4.2 & 2.1 & 0.36 \\
\hline BW-2A-G & 0.1 & $<0.04$ & 23 & 21 & 0.06 & 0.05 \\
\hline BW-3B-S & 1.0 & 0.19 & 4.4 & 4.9 & 2.1 & 0.35 \\
\hline $\mathrm{SC}-1$ & 3.7 & 0.45 & 0.02 & 0.02 & 43 & 42 \\
\hline SC-2 & 1.7 & 0.59 & 0.05 & 0.05 & 4.5 & 4.5 \\
\hline SM 1 & 0.2 & 0.05 & 1.4 & 1.3 & nd & nd \\
\hline SM 2 & 4.0 & 0.08 & 0.11 & 0.12 & 0.06 & 0.06 \\
\hline SM 3 & 3.6 & 0.81 & 0.16 & 0.14 & 0.56 & 0.55 \\
\hline SM 4 & 1.3 & 1.26 & 0.14 & 0.15 & 0.11 & 0.11 \\
\hline SM 5 & 0.5 & 0.13 & 0.13 & 0.11 & 0.22 & 0.21 \\
\hline SM 6 & 0.2 & $<0.04$ & 0.31 & 0.33 & 0.18 & 0.17 \\
\hline SM 7 & nd & nd & nd & nd & nd & nd \\
\hline SM 12 & 0.1 & 0.14 & 0.11 & 0.1 & 0.11 & 0.1 \\
\hline SM 17-S & 2.3 & $<0.04$ & 0.3 & 0.27 & 0.12 & 0.12 \\
\hline I-70-1 & 0.6 & 0.04 & 1.3 & 1.3 & 0.41 & 0.06 \\
\hline I-70-2 & 0.5 & 0.08 & 3.1 & 3.1 & nd & nd \\
\hline Sample no. & Cd mg/kg ICP-MS & Ce mg/kg ICP-MS & $\mathrm{Cl}$ mg/kg ISE & Co mg/kg ICP-MS & $\mathrm{Cr} \mathrm{mg} / \mathrm{kg}$ ICP-AES & $\mathrm{Cr}$ mg/kg ICP-MS \\
\hline AGEM-1B & $<0.1$ & 0.29 & $<50$ & 0.6 & 5 & 0.5 \\
\hline AGEM-2 & $<0.1$ & 0.38 & 100 & 0.4 & 10 & 0.5 \\
\hline BW-2A-S & 0.4 & 30 & 120 & 4.6 & 50 & 32 \\
\hline BW-2A-G & $<0.1$ & 0.56 & $<50$ & 0.9 & 5 & 0.5 \\
\hline BW-3B-S & 0.4 & 34 & 190 & 4.2 & 40 & 27 \\
\hline $\mathrm{SC}-1$ & 0.2 & 29 & 150 & 5.3 & 20 & 7 \\
\hline $\mathrm{SC}-2$ & 0.2 & 92 & 90 & 5.7 & 60 & 42 \\
\hline SM 1 & $<0.1$ & 9.7 & nd & 1.3 & 10 & 0.5 \\
\hline SM 2 & 1.2 & 24 & $<50$ & 36 & 20 & 10 \\
\hline SM 3 & 1.4 & 25 & $<50$ & 27 & 10 & 5 \\
\hline SM 4 & 0.8 & 13 & 60 & 7.8 & 20 & 16 \\
\hline SM 5 & 0.2 & 21 & $<50$ & 1.7 & 20 & 11 \\
\hline SM 6 & $<0.1$ & 7.4 & 810 & 1.7 & 10 & 2 \\
\hline SM 7 & ins & nd & nd & nd & nd & nd \\
\hline SM 12 & 0.3 & 19 & $<50$ & 0.2 & 5 & 2 \\
\hline SM 17-S & 0.2 & 4.8 & $<50$ & 2.5 & 20 & 8 \\
\hline I-70-1 & $<0.1$ & 31 & 360 & 1.7 & 20 & 8 \\
\hline I-70-2 & 0.2 & 17 & nd & 2.2 & 20 & 7 \\
\hline
\end{tabular}


Table AllI-2. Chemical data for all geologic samples collected in this study.-Continued

\begin{tabular}{|c|c|c|c|c|c|c|c|c|}
\hline Sample no. & F mg/kg ISE & $\mathrm{Fe} \%$ ICP-AES & $\mathrm{Fe} \%$ ICP-MS & Ga mq/kq ICP-MS & $\mathrm{Hq} \mathrm{mq} / \mathrm{kq}$ CVAA & K \% ICP-AES & K \% ICP-MS & La mg/kg ICP-MS \\
\hline AGEM-1B & 10 & 0.005 & 0.01 & 0.12 & $<0.02$ & 0.01 & 0.02 & 0.3 \\
\hline AGEM-2 & 60 & 0.03 & 0.02 & 0.17 & $<0.02$ & 0.01 & 0.03 & 0.3 \\
\hline BW-2A-S & 540 & 1.55 & 1.3 & 98 & $<0.02$ & 1.5 & 1.4 & 15 \\
\hline BW-2A-G & 30 & 0.02 & 0.02 & 0.22 & $<0.02$ & 0.03 & 0.04 & 0.3 \\
\hline BW-3B-S & 520 & 1.31 & 1.5 & 7.6 & 0.02 & 1.3 & 1.5 & 18 \\
\hline $\mathrm{SC}-1$ & 270 & 0.17 & 0.15 & 13 & 0.14 & 0.2 & 0.13 & 15 \\
\hline SC-2 & 840 & 1.51 & 1.8 & 20 & 0.11 & 2.3 & 2.4 & 47 \\
\hline SM 1 & nd & 0.23 & 0.25 & 1.7 & $<0.02$ & 0.08 & 0.08 & 4.8 \\
\hline SM 2 & 130 & 3.2 & 3.3 & 14 & $<0.02$ & 0.4 & 0.37 & 9.1 \\
\hline SM 3 & 560 & 0.41 & 0.39 & 3.8 & 0.77 & 0.18 & 0.14 & 10 \\
\hline SM 4 & 260 & 21.4 & 21 & 37 & 0.54 & 3.8 & 3.9 & 5.7 \\
\hline SM 5 & 110 & 2.5 & 2.5 & 15 & $<0.02$ & 0.57 & 0.52 & 11 \\
\hline SM 6 & 90 & 0.91 & 1 & 3.0 & $<0.02$ & 0.42 & 0.43 & 3.9 \\
\hline SM 7 & nd & nd & nd & nd & $<0.02$ & nd & nd & nd \\
\hline SM 12 & 40 & 0.12 & 0.08 & 1.1 & 1.1 & 0.02 & 0.01 & 13 \\
\hline SM 17-S & 60 & 0.94 & 0.92 & $\begin{array}{l}1.1 \\
8.9\end{array}$ & $<0.02$ & 0.44 & 0.38 & 2 \\
\hline I-70-1 & 130 & 0.49 & 0.51 & $\begin{array}{l}0.9 \\
4.5\end{array}$ & $<0.02$ & 1.2 & 1.2 & 18 \\
\hline $\mathrm{I}-70-2$ & nd & 0.35 & 0.36 & 3.4 & $<0.02$ & 0.78 & 0.77 & 9.3 \\
\hline Sample no. & Mg \% ICP-AES & Mg \% ICP-MS & \multicolumn{2}{|c|}{ Mn mg/kg ICP-MS } & gg ICP-MS & la \% ICP-AES & Na \% ICP-MS & Nb mg/kg ICP-MS \\
\hline AGEM-1B & 0.005 & 0.005 & \multicolumn{2}{|c|}{5} & 0.18 & 0.03 & 0.01 & 0.4 \\
\hline AGEM-2 & 0.1 & 0.09 & \multicolumn{2}{|c|}{6} & 0.69 & 0.005 & 0.02 & 0.2 \\
\hline BW-2A-S & 1.8 & 1.5 & \multicolumn{2}{|c|}{235} & 1.3 & 1.64 & 1.3 & 4.6 \\
\hline BW-2A-G & 0.02 & 0.02 & \multicolumn{2}{|c|}{17} & 0.09 & 0.02 & 0.02 & 0.2 \\
\hline BW-3B-S & 1.6 & 1.8 & \multicolumn{2}{|c|}{185} & 1.2 & 2.78 & 2.5 & 4.3 \\
\hline $\mathrm{SC}-1$ & 0.12 & 0.11 & 2 & & 1.1 & 0.2 & 0.13 & 11 \\
\hline SC-2 & 0.39 & 0.45 & 4 & & 1.2 & 0.82 & 0.76 & 12 \\
\hline SM 1 & 11 & 10 & 3 & & 0.18 & 0.005 & 0.02 & 1.8 \\
\hline SM 2 & 1.1 & 1.1 & 74 & & 0.45 & 1.02 & 0.81 & 0.4 \\
\hline SM 3 & 1.5 & 1.5 & 73 & & 0.82 & 0.1 & 0.08 & 2.4 \\
\hline SM 4 & 0.24 & 0.24 & 17 & & 6 & 1.1 & 0.97 & 2.3 \\
\hline SM 5 & 0.37 & 0.37 & 7 & & 0.35 & 0.68 & 0.49 & 2.1 \\
\hline SM 6 & 6.3 & 7.2 & 2 & & 0.28 & 9.85 & 8.3 & 1.0 \\
\hline SM 7 & nd & nd & $\mathrm{n}$ & & nd & nd & nd & nd \\
\hline SM 12 & 0.01 & 0.01 & 1 & & 0.32 & 0.05 & 0.01 & 1.9 \\
\hline SM 17-S & 2.0 & 2.0 & 9 & & 0.4 & 12.9 & 10.7 & 0.3 \\
\hline I-70-1 & 0.54 & 0.57 & 11 & & 0.23 & 13.6 & 11.9 & 3.5 \\
\hline I-70-2 & 1.3 & 1.4 & 6 & & 0.87 & 18 & 14.9 & 2.1 \\
\hline
\end{tabular}


Table Alll-2. Chemical data for all geologic samples collected in this study.-Continued

\begin{tabular}{|c|c|c|c|c|c|c|c|}
\hline Sample no. & Ni mg/kg ICP-MS & P mg/kg ICP-MS & $\mathrm{Pb} \mathrm{mg} / \mathrm{kg}$ ICP-MS & Rb mg/kg ICP-MS & S \% ICP-MS & S (tot) \% COMB & Sb mg/kg ICP-MS \\
\hline AGEM-1B & 1.5 & $<50$ & 1.2 & 0.6 & 22 & 17 & 0.03 \\
\hline AGEM-2 & 1.2 & 180 & 1.0 & 1.3 & 23 & 23 & 0.08 \\
\hline BW-2A-S & 18 & 710 & 15 & 66 & 1.4 & 1.11 & 0.67 \\
\hline $\mathrm{BW}-2 \mathrm{~A}-\mathrm{G}$ & 1.7 & $<50$ & 0.6 & 1.4 & 23 & 17 & 0.06 \\
\hline BW-3B-S & 18 & 960 & 15 & 59 & 2.4 & 1.59 & 0.68 \\
\hline SC-1 & 13 & $<50$ & 13 & 6 & 0.49 & 0.78 & 1.5 \\
\hline $\mathrm{SC}-2$ & 16 & 450 & 30 & 160 & 0.82 & 0.6 & 1.3 \\
\hline SM 1 & 2.6 & $<50$ & 4.5 & 4 & 14 & nd & 0.1 \\
\hline SM 2 & 43 & $<50$ & 8.1 & 8.8 & 11 & 14 & 0.07 \\
\hline SM 3 & 27 & $<50$ & 5.9 & 8.4 & 8.8 & 12 & 0.26 \\
\hline SM 4 & 15 & 100 & 81 & 86 & 14 & 12 & 1.2 \\
\hline SM 5 & 4.7 & 170 & 4.9 & 27 & 7.05 & 17 & 0.12 \\
\hline SM 6 & 3.9 & $<50$ & 2.3 & 12 & 18 & 16 & 0.07 \\
\hline SM 7 & nd & nd & nd & nd & nd & nd & nd \\
\hline SM 12 & 0.9 & 160 & 11 & 0.7 & 1.2 & 18 & 0.19 \\
\hline SM 17-S & 6.8 & 210 & 1.3 & 7.9 & 18 & 19 & 0.03 \\
\hline $\mathrm{I}-70-1$ & 4.8 & 310 & 10 & 43 & 8.9 & 8.2 & 0.29 \\
\hline $\mathrm{I}-70-2$ & 5.8 & 140 & 6.5 & 25 & 13 & nd & 0.25 \\
\hline Sample no. & Sc mg/kg ICP-MS & Se mg/kg Hydride & Si \% ICP-AES & Sn mg/kg ICP-MS & Sr mg/kg ICP-AES & Sr mg/kg ICP-MS & Th mg/kg ICP-MS \\
\hline AGEM-1B & 0.4 & $<0.2$ & 0.02 & 0.05 & 1,230 & 1,210 & 0.1 \\
\hline AGEM-2 & 0.4 & $<0.2$ & 0.03 & 0.1 & 1,440 & 1,250 & 0.1 \\
\hline BW-2A-S & 6.1 & 1.2 & 28 & 1.2 & 190 & 175 & 6.6 \\
\hline BW-2A-G & 0.6 & 0.5 & 0.17 & 0.1 & 380 & 350 & 0.1 \\
\hline BW-3B-S & 4.7 & 1 & 27 & 1.0 & 150 & 155 & 6.1 \\
\hline $\mathrm{SC}-1$ & 5.2 & 1.8 & 8.5 & 1.1 & 30 & 18 & 8.4 \\
\hline $\mathrm{SC}-2$ & 9.2 & 1.7 & 27 & 2.4 & 140 & 135 & 15 \\
\hline SM 1 & 0.5 & 0.7 & 2.3 & 0.4 & 60 & 53 & 1.8 \\
\hline SM 2 & 6.5 & 0.5 & 0.82 & 0.4 & 30 & 27 & 11 \\
\hline SM 3 & 2.8 & 1.4 & 5.3 & 0.6 & 40 & 36 & 3.9 \\
\hline SM 4 & 4.6 & 0.9 & 4.3 & 3.5 & 100 & 96 & 11 \\
\hline SM 5 & 3.9 & $<0.2$ & 5.5 & 0.6 & 160 & 140 & 3.4 \\
\hline SM 6 & 0.7 & 0.2 & 3.1 & 0.3 & 130 & 130 & 1.2 \\
\hline SM 7 & nd & $<0.2$ & nd & nd & nd & nd & nd \\
\hline SM 12 & 0.8 & 0.3 & 33 & 0.4 & 30 & 21 & 0.9 \\
\hline SM 17-S & 3.7 & 0.6 & 1.7 & 0.2 & 120 & 105 & 1.6 \\
\hline I-70-1 & 1.7 & 3.6 & 22 & 0.5 & 220 & 210 & 4.4 \\
\hline I-70-2 & 1.4 & 7.9 & 12 & 0.4 & 450 & 120 & 2.5 \\
\hline
\end{tabular}


Table Alll-2. Chemical data for all geologic samples collected in this study.-Continued

\begin{tabular}{|c|c|c|c|c|c|c|c|}
\hline Sample no. & Ti \% ICP-MS & $\mathrm{TI} \mathrm{mg} / \mathrm{kg} \mathrm{GF}$ & TI mg/kg ICP-MS & U mg/kg ICP-MS & V mg/kg ICP-MS & W mg/kg ICP-MS & Y mg/kg ICP-MS \\
\hline AGEM-1B & $<0.01$ & 0.4 & $<0.1$ & 0.05 & 0.5 & 0.1 & 0.05 \\
\hline AGEM-2 & $<0.01$ & $<0.1$ & $<0.1$ & 0.05 & 0.5 & 1.3 & 0.1 \\
\hline BW-2A-S & 0.12 & 0.6 & 0.5 & 2.5 & 72 & 0.6 & 13 \\
\hline $\mathrm{BW}-2 \mathrm{~A}-\mathrm{G}$ & $<0.01$ & $<0.1$ & $<0.1$ & 0.05 & 1.0 & 0.05 & 0.2 \\
\hline BW-3B-S & 0.11 & 0.5 & 0.5 & 2.3 & 73 & 0.6 & 13 \\
\hline $\mathrm{SC}-1$ & 0.12 & $<0.1$ & 0.1 & 4.6 & 27 & 0.3 & 14 \\
\hline $\mathrm{SC}-2$ & 0.31 & 1.1 & 1.1 & 5.5 & 120 & 1.7 & 18 \\
\hline SM 1 & 0.02 & $<0.1$ & $<0.1$ & 0.6 & 3 & 0.3 & 2.8 \\
\hline SM 2 & $<0.01$ & 0.6 & 0.5 & 0.7 & 6 & 0.05 & 12 \\
\hline SM 3 & 0.04 & 1 & 0.8 & 0.9 & 7 & 1.5 & 17 \\
\hline SM 4 & 0.05 & 6.3 & 6.5 & 1.0 & 41 & 1.2 & 7.9 \\
\hline SM 5 & 0.04 & 0.4 & 0.3 & 0.6 & 27 & 0.3 & 5.5 \\
\hline SM 6 & 0.02 & 0.6 & 0.6 & 0.9 & 7 & 0.2 & 2.1 \\
\hline SM 7 & nd & nd & nd & nd & nd & nd & nd \\
\hline SM 12 & 0.04 & 0.3 & 0.3 & 5.9 & 3 & 0.6 & 345 \\
\hline SM 17-S & $<0.01$ & 0.2 & 0.2 & 1.0 & 36 & 0.2 & 4.4 \\
\hline I-70-1 & 0.09 & 0.2 & 0.2 & 0.9 & 24 & 0.5 & 6.4 \\
\hline $\mathrm{I}-70-2$ & 0.05 & ins & 0.2 & 0.8 & 17 & 0.4 & 4.2 \\
\hline \multicolumn{3}{|c|}{ Sample no. } & \multicolumn{2}{|c|}{ Zn mg/kg ICP-MS } & \multicolumn{3}{|c|}{$\mathrm{Zr} \mathrm{mg/kg} \mathrm{ICP-AES}$} \\
\hline \multicolumn{3}{|c|}{ AGEM-1B } & \multicolumn{2}{|c|}{0.5} & \multicolumn{3}{|c|}{5} \\
\hline & AGEM-2 & & \multicolumn{2}{|c|}{1} & \multicolumn{3}{|c|}{5} \\
\hline & $\mathrm{BW}-2 \mathrm{~A}-\mathrm{S}$ & & \multicolumn{2}{|c|}{59} & \multicolumn{3}{|c|}{260} \\
\hline & BW-2A-G & & \multicolumn{2}{|c|}{1} & \multicolumn{3}{|c|}{5} \\
\hline & BW-3B-S & & \multicolumn{2}{|c|}{63} & \multicolumn{3}{|c|}{270} \\
\hline & $\mathrm{SC}-1$ & & \multicolumn{2}{|c|}{42} & \multicolumn{3}{|c|}{140} \\
\hline & $\mathrm{SC}-2$ & & \multicolumn{2}{|c|}{56} & \multicolumn{3}{|c|}{210} \\
\hline & SM 1 & & \multicolumn{2}{|c|}{11} & \multicolumn{3}{|c|}{30} \\
\hline & SM 2 & & \multicolumn{2}{|c|}{280} & \multicolumn{3}{|c|}{10} \\
\hline & SM 3 & & \multicolumn{2}{|c|}{195} & \multicolumn{3}{|c|}{60} \\
\hline & SM 4 & & \multicolumn{2}{|c|}{64} & \multicolumn{3}{|c|}{80} \\
\hline & SM 5 & & & & & 70 & \\
\hline & SM 6 & & & & & 40 & \\
\hline & SM 7 & & & & & nd & \\
\hline & SM 12 & & & & & 100 & \\
\hline & SM 17-S & & & & & 10 & \\
\hline & I-70-1 & & & & & 140 & \\
\hline & I-70-2 & & & & & 80 & \\
\hline
\end{tabular}


Table Alll-3. Sulfur isotope data for geologic samples collected in this study.

$\left[\mathrm{S}\left(\mathrm{H}_{2} 0\right)\right.$, sulfate that dissolves in water; $\mathrm{S}(\mathrm{HCl})$, sulfate that dissolves in acid; $\mathrm{S}($ elem), elemental sulfur; $\mathrm{S}(\mathrm{av})$, sulfur in monosulfide minerals; $\mathrm{S}(\mathrm{DI})$, sulfur in disulfide minerals such as pyrite; nq, not quantified. Blanks indicate no data; oxygen isotopes reported relative to V-SMOW and sulfur isotopes relative to V-CDT]

\begin{tabular}{|c|c|c|c|c|c|c|}
\hline Sample no. & Site & Location & Sample type & lat & long & $\% \mathrm{~S}\left(\mathrm{H}_{2} \mathbf{O}\right)$ \\
\hline AGEM-1A & American Gypsum Eagle mine & near surface & gypsum (var. selenite) & 39.67597 & -106.95027 & 9.7 \\
\hline AGEM-1B & American Gypsum Eagle mine & near surface-hi-grade ore & massive gypsum & 39.67597 & -106.95027 & 9.8 \\
\hline AGEM-2 & American Gypsum Eagle mine & deeper low-grade & massive gypsum & 39.67597 & -106.95027 & 7.1 \\
\hline BW-3BS & Badger Wash & near entrance to Basin $3 \mathrm{~B}$ & salts & 39.34320 & -108.93324 & 1.6 \\
\hline BW-2AG & Badger Wash & near entrance to Basin $2 \mathrm{~A}$ & gypsum & 39.3316 & -108.93684 & 9.2 \\
\hline BW-2AS & Badger Wash & near entrance to Basin $2 \mathrm{~A}$ & salt & 39.3317 & -108.93697 & 1.0 \\
\hline SM-1 & Sulfur mine & middle working (the ridge) & fine white powder & 38.79016 & -107.84089 & 13 \\
\hline SM-2 & Sulfur mine & middle working (the ridge) & yellow popcorn salt & 38.79016 & -107.84089 & 12 \\
\hline SM-3 & Sulfur mine & middle working (the ridge) & white-gray popcorn salt & 38.79016 & -107.84089 & 12 \\
\hline SM-4 & Sulfur mine & middle working (the ridge) & gray-white-yellow hard layer & 38.79016 & -107.84089 & 8.0 \\
\hline SM-5 & Sulfur mine & middle working (the ridge) & soft gray (ash-feeling) salt & 38.79016 & -107.84089 & 15 \\
\hline SM-6 & Sulfur mine & middle working (the ridge) & lowermost white salt & 38.79016 & -107.84089 & 16 \\
\hline SM-7 & Sulfur mine & middle working (the ridge) & massive $x l$ mat-white salt & 38.79016 & -107.84089 & 11 \\
\hline SM-8 & Sulfur mine & middle working (the ridge) & massive siliceous layer & 38.79016 & -107.84089 & \\
\hline SM-9 & Sulfur mine & middle working (the ridge) & yellow-white massive salt & 38.79016 & -107.84089 & \\
\hline SM-10 & Sulfur mine & middle working (the ridge)-down stream & cherty silicified layer & 38.79016 & -107.84092 & \\
\hline SM-11 & Sulfur mine & middle working (the ridge)-down stream & S(native) on fractures & 38.79016 & -107.84092 & \\
\hline SM-12 & Sulfur mine & lower workings "S face" & sandstone with native $\mathrm{S}$ & 38.78923 & -107.84168 & \\
\hline SM-17 & Sulfur mine & lower workings pond in main drainage & salts from bank & 38.78923 & -107.84168 & $\mathrm{nq}$ \\
\hline $\mathrm{SC}-1$ & Snowcap coal & coal on outcrop outside mine & coal & 39.1423 & -108.31345 & \\
\hline $\mathrm{SC}-2$ & Snowcap coal & shale on outcrop outside mine & shale & 39.1423 & -108.31345 & \\
\hline $\mathrm{I}-70-1$ & Mesa Verde & I-70 parking (between Cameo/Debeque) & massive salt & 39.19412 & -108.27422 & 8.7 \\
\hline $\mathrm{I}-70-2$ & Mesa Verde & I-70 parking (between Cameo/Debeque) & salt scraping & 39.19412 & -108.27422 & 17 \\
\hline
\end{tabular}


Table Alll-3. Sulfur isotope data for geologic samples collected in this study.-Continued

$\left[\mathrm{S}\left(\mathrm{H}_{2} 0\right)\right.$, sulfate that dissolves in water; $\mathrm{S}(\mathrm{HCl})$, sulfate that dissolves in acid; $\mathrm{S}(\mathrm{elem})$, elemental sulfur; $\mathrm{S}(\mathrm{av})$, sulfur in monosulfide minerals; $\mathrm{S}(\mathrm{DI})$, sulfur in disulfide minerals such as pyrite; nq, not quantified. Blanks indicate no data; oxygen isotopes reported relative to V-SMOW and sulfur isotopes relative to V-CDT]

\begin{tabular}{|c|c|c|c|c|c|c|c|c|c|c|}
\hline Sample & $\delta^{34} \mathbf{S}\left(\mathbf{H}_{2} \mathbf{0}\right) \%$ & $\delta^{18} \mathbf{O}\left(\mathbf{H}_{2} \mathbf{O}\right)$ & $\% \mathrm{~S}$ (HCl-1N) & $\delta^{34} \mathbf{S}(\mathbf{H C I}) \%$ & $\%$ S(elem) & $\delta^{34}$ S(ele) $\%$ & $\%$ S(AV) & $\delta^{34} \mathbf{S}(\mathbf{A V}) \%$ & $\%$ S(DI) & $\delta^{34} \mathbf{S}(\mathbf{D i}) \%$ \\
\hline AGEM-1A & 14.5 & 12.6 & 8.2 & 14.5 & & & & & & \\
\hline AGEM-1B & 14.3 & 11.5 & 7.8 & 14.1 & & & & & & \\
\hline AGEM-2 & 13.7 & 10.2 & 13 & 13.6 & & & & & & \\
\hline BW-3BS & -20.9 & -9.0 & 0.014 & nd & & & & & & \\
\hline BW-2AG & -22.7 & -2.9 & 7.9 & -22.8 & & & & & & \\
\hline BW-2AS & -17.0 & -8.6 & 0.019 & nd & & & & & & \\
\hline SM-1 & -6 & -7.5 & 0.027 & nd & & & & & & \\
\hline SM-2 & -1.5 & -4.0 & & -2.0 & 0.004 & nd & & & & \\
\hline SM-3 & -3.7 & -4.6 & & & 0.003 & nd & & & & \\
\hline SM-4 & 1.7 & -5.0 & nq & -3.2 & 0.006 & nd & & & & \\
\hline SM-5 & 1.3 & nd & 0.008 & nd & & & & & & \\
\hline SM-6 & -18.9 & -3.7 & 0.014 & nd & & & & & & \\
\hline SM-7 & -1.5 & 13.6 & & & 0.087 & nd & & & & \\
\hline \multicolumn{11}{|l|}{ SM-8 } \\
\hline \multicolumn{11}{|l|}{ SM-9 } \\
\hline \multicolumn{11}{|l|}{ SM-10 } \\
\hline \multicolumn{11}{|l|}{ SM-11 } \\
\hline SM-12 & & & $\mathrm{nq}$ & -0.4 & 6.2 & 4.5 & 0.67 & 2.80 & 6.7 & 3.9 \\
\hline SM-17 & -7.4 & 2.9 & & & 0.025 & nd & & & & \\
\hline SC-1 & & & $\mathrm{nq}$ & 3.7 & 0.003 & nd & 0.0003 & nd & 0.034 & nd \\
\hline $\mathrm{SC}-2$ & & & $\mathrm{nq}$ & -1.5 & 0.008 & nd & 0.0010 & nd & 0.006 & nd \\
\hline I-70-1 & 3.4 & -3.6 & 0.011 & nd & & & & & & \\
\hline I-70-2 & 3.6 & -2.9 & 0.014 & nd & & & & & & \\
\hline
\end{tabular}


Table Alll-4. Mineralogical data for selected geologic samples collected in this study. Data on elements present in the samples are based on examination with a scanning electron microscope (SEM) equipped with an energy dispersive X-ray fluorescence detector. Elements are listed in order of abundance, except 0 , which is always listed last. Mineral identification is based on morphology and element suites.

[*, amount of hydroxyl present in each sample was not determined and may have changed between the time of sample collection and SEM examination]

\begin{tabular}{|c|c|c|c|c|c|}
\hline Sample & Site & Location & Sample type & Elements* & $\begin{array}{l}\text { Interpreted } \\
\text { minerals }\end{array}$ \\
\hline AGEM-1A & American Gypsum Eagle mine & near surface & gypsum (var. selenite) & nd & gypsum \\
\hline AGEM-1B & American Gypsum Eagle mine & near surface-hi-grade ore & massive gypsum & nd & gypsum \\
\hline AGEM-2 & American Gypsum Eagle mine & deeper low-grade & massive gypsum & nd & gypsum \\
\hline BW-3BS & Badger Wash & near entrance to Basin 3B & salts & $\mathrm{NaSO}, \mathrm{CaSO}$ & thenardite, gypsum \\
\hline BW-2AG & Badger Wash & near entrance to Basin $2 \mathrm{~A}$ & gypsum & $\mathrm{CaSO}$ & gypsum \\
\hline BW-2AS & Badger Wash & near entrance to Basin 2A & salt & $\mathrm{NaSO}$ & thenardite \\
\hline SM-1 & Sulfur mine & middle working (the ridge) & fine white powder & NaAlSO, MgAlSO, Fe(NaSiK)SO & \\
\hline SM-2 & Sulfur mine & middle working (the ridge) & yellow popcorn salt & $\mathrm{MgSO}, \mathrm{CaSO}$ & \\
\hline SM-3 & Sulfur mine & middle working (the ridge) & white-gray popcorn salt & $\begin{array}{l}\text { AlMgSO, AlSO, MgAlSO, CaSO, } \\
\text { FeSO, NaAlSO, AlSiSO }\end{array}$ & \\
\hline SM-4 & Sulfur mine & middle working (the ridge) & gray-white-yellow hard layer & $\mathrm{AlMgSO}, \mathrm{AlSO}$ & \\
\hline SM-5 & Sulfur mine & middle working (the ridge) & soft gray (ash-feeling) salt & AlSO, FeSO, KFeAlMgSO & voltaite(?) \\
\hline SM-6 & Sulfur mine & middle working (the ridge) & lowermost white salt & $\begin{array}{l}\mathrm{NaMgSO}, \mathrm{S}, \mathrm{MgSO}, \mathrm{NaAlSO}, \\
\text { AlMgSO, KAlSO }\end{array}$ & native sulfur \\
\hline SM-7 & Sulfur mine & middle working (the ridge) & massive $\mathrm{xl}$ mat — white salt & MgAlSO, MgFeAlSO, AlSO & voltaite(?) \\
\hline SM-8 & Sulfur mine & middle working (the ridge) & massive siliceous layer & & \\
\hline SM-9 & Sulfur mine & middle working (the ridge) & yellow-white massive salt & & \\
\hline SM-10 & Sulfur mine & middle working (the ridge)-down stream & cherty silicified layer & & \\
\hline SM-11 & Sulfur mine & middle working (the ridge)-down stream & $\mathrm{S}$ (native) on fractures & & \\
\hline SM-12 & Sulfur mine & lower workings "S face" & sandstone with native $\mathrm{S}$ & & \\
\hline SM-17 & Sulfur mine & lower workings pond in main drainage & salts from bank & $\mathrm{NaSO}, \mathrm{NaFeSO}, \mathrm{NaAlSO}, \mathrm{NaMgSO}$ & \\
\hline SC-1 & Snowcap coal & coal on outcrop outside mine & coal & nd & nd \\
\hline $\mathrm{SC}-2$ & Snowcap coal & shale on outcrop outside mine & shale & nd & nd \\
\hline $\mathrm{I}-70-1$ & Mesa Verde & I-70 parking (between Cameo/Debeque) & Salt scraping-massive and dendritic & NaSO rounded xls & thenardite \\
\hline $\mathrm{I}-70-2$ & Mesa Verde & I-70 parking (between Cameo/Debeque) & $\begin{array}{l}\text { salt scraping-massive white salt, } \\
\text { some dendritic xls }\end{array}$ & $\mathrm{NaSO}, \mathrm{CaSO}, \mathrm{NaCaSO}, \mathrm{NaMgSO}$ & thenardite, gypsum \\
\hline
\end{tabular}


Publishing support provided by:

Denver Publishing Service Center, Denver, Colorado

Manuscript approved for publication, March 13, 2009

Edited by Thomas Judkins

Graphics and layout by Joy Monson

For more information concerning this publication, contact:

Team Chief Scientist, USGS Crustal Imaging and Characterization

Box 25046, Mail Stop 964

Denver, C0 80225

(303) 236-1312

Or visit the Crustal Imaging and Characterization Team Web site at: http://crustal.usgs.gov/

This publication is available online at: http://pubs.usgs.gov/sir/2009/5072/ 